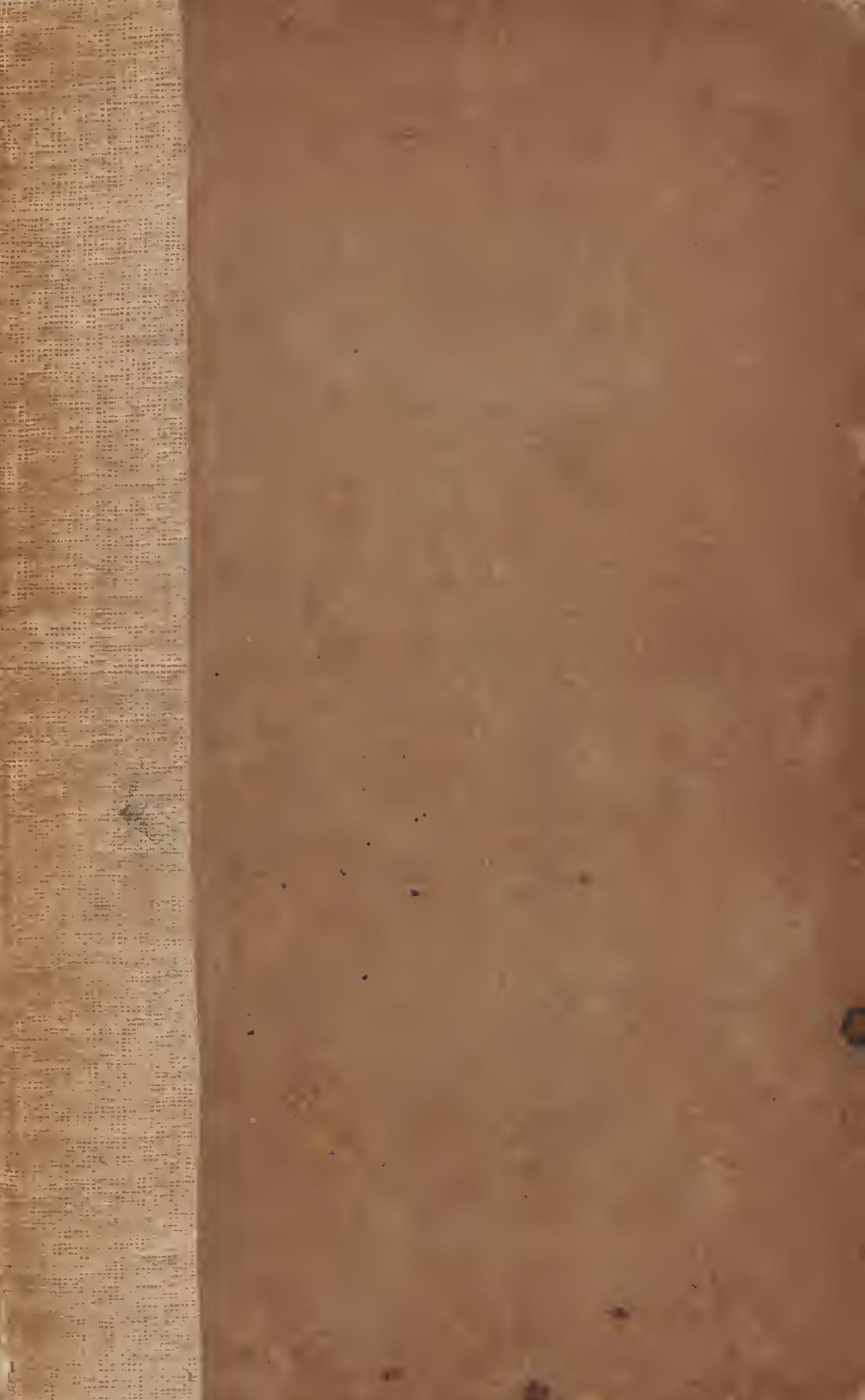




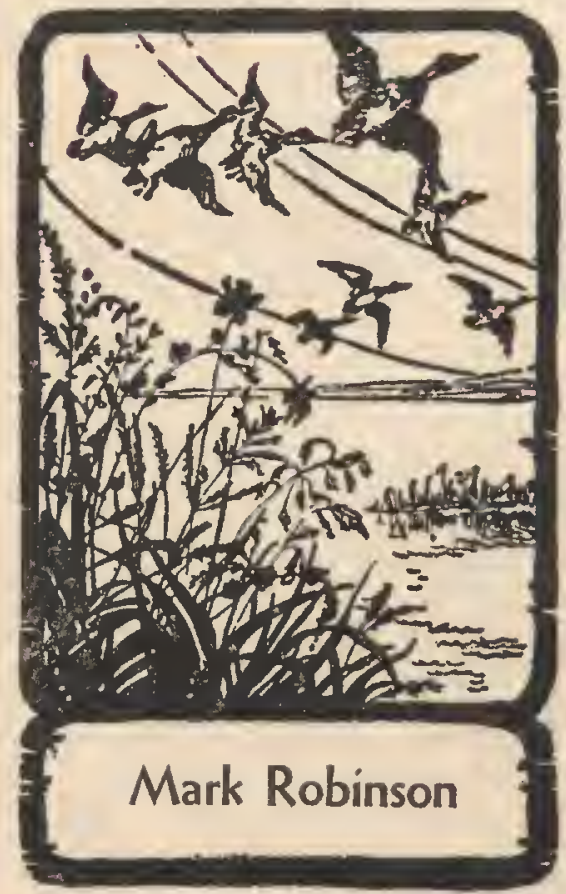


ENHOTHECA

C. UC NULOAICA

L.B. Holthuis 



\section{JOURNAL}

$O F$

\section{THE ACADEMY OF NATURAL SCIENCES}

OF

I’H I LA D ELPH I A.

VOLUME VIII. PART I.

P H I L A D L P H IA:

MLKRIHEW A N THOMPSON, WKINTEIR, No. 7 Carter's Alley.

1839. 



\section{CONTENTS OF VOLUME V1I1.-PAR'T 1.}

Officers of the Academy of Natural Sciences of Philadeldelphia, for the year 1839,

Descriptions of new North American Neuropterous In. sects, and Observations on some already described. By (the late) Thomas Say,

Summary of Meteorological Observations for 1836 ; made in Fayette county, Tennessee. By M. Rhea, .

Description of five new Fossils, of the older Pliocene formation of Maryland and North Carolina. By

Wm. Wagncr, - - • • • • •

A few facts in relation to the identity of the Red and

Mottled Owls, \&cc. By Ezra Michener, M. D., •

Description of screral new Species of American Quadrupeds. By Rev. J. Bachman, of Charleston, S. C.,

List of Quadrupeds procured by Mr. Townsend, and sent to the Academy of Natural Sciences,
Additional remarks on the genus Lepus, with corrections of a former paper, and descriptions of other Species of Quadrupeds found in North America. By John Bachman,

Additional Species to the list of Mr. Townsend's Quad-

rupeds, - - - -4 by Thomas Nuttall

Catalogue of the Crustacea brought by Thomas Nuttall and J. K.' 'Townsend, from the West Coast of North America and the Sandwich Islands, with descriptions of such species as are apparently new, among which are included several species of different localities, previously existing in the collection of the Academy. By J. W. Randall, • • - 106 


\section{CONTENTS.}

Description of a new Species of Cypcelus, from the Co. lumbia River. By John K. Townsend, - . 148

Description of a new Species of Sylvia, from the Columbia River. By John K. Townsend, - • _ _ 149

An Analysis of Marl, from New Jersey. By S. S. Haldeman, -

List of Birds inhabiting the region of the Rocky Mountains, the Territory of the Oregon, and the North West Coast of America. By John K. Townsend, Note on Sylvia Tolmœi. By John K Townsend, -

Description of the White-winged Tanager, (Pyranga leucoptera.) By J. Trudeau, - - - . 160

Description of a Species of Land Tortoise, from Africa. By Edward Hallowell, M. D, - • . . 161 
OF FICERS.

President.

\section{WILI.IAM MACIURE.}

Vice Presidents.

WILIIAM HEMBEL,

JOHN PRICE WFTIERII.

Corresponding Secretary.

SAMUEL GEORGE MORTON, M. D.

Recording Secretary.

THOMAS STEWARDSON, M, n.

Treasurer.

GFORCE W. CARPENTER.

Iibrurian.

ATFRED A. FLWYN, M. D.

Curators.

THOMAS M'EUEN, M. D.

IVILLIAM VAUX.

NDIVARD HALI.OWHILI, M. D.

WATTER R, JOHNSON. 


\section{COMMITTEE OF PUBI,ICATION.}

ALFRED A. ELWYN, M. D. JOSEPH CARSON, M. D. ROBEHT BRIDGES, M. D. EDWARD HALLOWVEI.I, M. D. T. A, CONRAD. 
J O URNAL

OF THE

\title{
ACADEMY OF NATURAL SCIENCES
}

\author{
OF
}

PHILA D E L P H IA.

Descriptions of New North American Neuropterous Insects, and Observations on some already described. By (the late) Thomas Say.

Read July 12th, 1836.

Eshna, Fabr.

† Eyes in contact above.

1. AE. multicincia. Reddish-brown; thorax with green lines and spots; abdomen with green bands and lateral vitta.

Inhabits Indiana.

Q Body reddish-brown; eyes connate, dull greenish above, with a semiocellate blackish mark, and on the posterior margin pale bluish, including a black line; inferior portion tinged with gray, and with several moveable internal spots; frontal vesicle dull whitish, above reddish-brown, dull yellowish in the middle, with a quadrate blackish spot; VOL. VIII. -1839 . 
thorar with two anterior green lines, and on the pleura beneath each wing, also a green oblique line, between the bases of the wings are green spots; wings immaculate, tinged with ferruginous, carpal spot fuscous; accessory membrane opaque white; abdomen with a lateral, angulated and almost interrupted green vitta; segments with a double green, sutural, narrow band, and in the middle of each, another narrow band, excepting the three ultimate ones, on which are but single sutural bands; caudal foliaceous processes blackish, somewhat dilated in the middle, gradually narrowed to each extremity, and rounded at tip; feet black; thighs rufous at base.

Length $3 \frac{3}{5}$ inches to tip of caudal appendices.

The abdomen tapers gradually from the base to the tip. The description is taken from a recent specimen.

[This species, which is common throughout the United States, has usually been referred to the heros of Fabricius.-E. - . ]

2. A. junius. Green; abdomen brown, laterally bluish; wings immaculate.

L. junius, Drury, Vol. I., pl. 47, fig. 5.

s Body bright green; eyes brown, tinged behind and beneath with yellowish; labium yellowish; antennæ and intervening line black; frontal vesicle above with an arcuated blue line and central black dot; wings immaculate; carpal spot pale brown; posterior wings, next to the body and behind the nervures, with a small opaque white spot, terminated by a black, broad line; feet rufous; tibiæ and tarsi 
black; abdomen with a dorsal and lateral interrupted raised line; brown above, with a lateral, interrupted blue vitta, originating with the second segment; first and second segments bright green; venter tinged with brown, with a blackish vitta; foliaceous appendices carinate, at the exterior tip prominently mucronate.

Length three inches.

q Wings with a trace of ferruginous on the anterior portion; foliaceous appendages rather smaller, lanceolate, acute.

Drury in his figure represents the abdomen as entirely green; but this is a mistake; his dried specimen had this part brown, and supposing it to have been green when living, he figured it so. Can this be vesiculosa, L.? It is allied to the formosa, Vanderlinden, which, however, appears to have a black, angulated, dorsal vitta on the abdomen, and the eyes are described to be green.

3. E. constricta. Abdomen contracted near the base, elongated, with interrupted bands; anal processes undulated and prominently mucronate.

Inhabits Indiana.

EEyes in contact above; occiput black, with a yellow spot between the eyes; front greenish-yellow; between and behind the antennæ, with the exception of a yellow transverse spot, black, connected anteriorly with a transverse black line; stethidium brownish, varied with greenish vittæ before, and oblique ones on the pleura, and spots on base of the wings; wings hyaline, a little lactaceous; stigma moderate, black; anal membrane 
black, white at base; abdomen elongated, fuscous, with somewhat glaucous interrupted bands and spots; two basal segments thick, the second with a narrow interrupted band; third remarkably contracted in the middle, with two small transverse spots, and on the posterior margin an interrupted. band; remaining segments having the same markings as the third, together with a large double lateral longitudinal spot, excepting the ultimate and the caudal segments, which have only the posterior interrupted band; caudal segment two-thirds the length of the preceding one; anal processes as long as the two preceding segments, undulated, foliaceous, with a longitudinal line in the middle, dilated on the inner edge beyond the middle, near the inner tip, hairy, and with a tooth, and rounded prominence; at tip rounded, with a prominent cylindric spine; inferior process half the length of the superior ones; feet piceous, or blackish; anterior thighs with a glaucous line behind.

Length less than three inches.

The third abdominal segment is remarkably contracted. The posterior interrupted bands might be called rounded or quadrate spots, and are largest and more glaucous on the posterior segments. It resembles Libellula tenebrosa.?

4. A. clepsydra. Abdornen contracted near the base, with interrupted bands; anal processes foliaceous.

Inhabits Massachusetts.

This is so much like constricta, S., that it may possibly prove to be a variety. Nevertheless, the anal 
appendices are very different. These are foliaceous, oblong-oval, gradually narrowed at base, with a small angle at tip; upper side with a carinated line; caudal segment of the abdomen with an elevated compressed tooth near its base above.

Length less than three inches.

The only individual I have seen was sent me by Dr. Harris.

5. A. vinosa. Abdomen contracted near the base; wings very slightly tinged with ferruginous; stigma yellowish; pleura with two bright yellow orbicular spots.

Inhabits Massachusetts. Harris.

Length over two inches and a half.

Resembles clepsydra, S., very closely, but it may be distinguished by the color of the wings and stigma, the bright orbicular spots of the pleura, the yellow antennæ, and the absence of black markings on the summit of the frontal vesicle. The anal processes resemble those of clepsydra, and the neck of the wings is fuscous, as in janata, $\mathrm{S}$.

6. Æ. janata. Wings immaculate; abdomen contracted near the base, banded; anal processes at tip unarmed, pediform.

Inhabits Massachusetts.

$\checkmark$ Eyes in contact above; occiput dusky ; posterior canthus of the eyes dull yellowish; space between the eyes transversely triangular, depressed, dusky, excepting the posterior edge, which is yellowish, and is a raised line; antennæ and vertex black, excepting a transverse, obscure, arcuated line; front 
yellow; summit with a black line and anterior margin; thorax brown, two dull glaucous vittæ before; pleura, two oblique yellow vittæ, margined with black; wings hyaline, immaculate; basal neck fuscous; anal membrane white; stigma dull yellowish; abdomen dusky; third segment deeply contracted; segments with a yellowish band at base, interrupted one at tip and spot in the middle; caudal segment but little shorter than the preceding one, and carinate at base, beneath with the lateral tubercles of the second segment compressed and denticulated; caudal processes a little undulated, being slightly dilated beneath near the base, and more obviously so towards the tip, so as to be pediform; tip unarmed; inferior process hardly half as long as the superior ones; feet yellowish, blackish beneath.

Length over two inches.

Sent to me by Dr. Harris. I have not seen the female.

It resembles constricta, S., but is smaller, the caudal segment is subequal to the preceding segment, and the superior caudal processes are suddenly enlarged near the tip, and are unarmed.

7. A. furcillata. Inferior anal process widely forked at tip.

Inhabits Massachusetts.

s Body brownish; pleura with three oblique, yellow lines; between the wings varied with whitish; wings immaculate, anal membrane white; stigma fuscous; abdomen, third segment very much contracted; segments with a double spot at tip, a 
smaller double one in the middle, and a triangular spot at base; anal processes narrow, foliaceous, on their basal half subcylindrical, with two small distant teeth on the inner inferior side; beyond the middle rectilinear, flattened, sides parallel, rounded at tip; inferior process about half as long as the superior pair, wide, widely emarginate down to its middle.

Length over two inches.

This may readily be distinguished by the widely forked form of the inferior caudal process. I have seen but the individual sent me for examination by Dr. Harris.

8. A. obliqua. Thorax brown, with two oblique yellow vittæ before; front yellow, with a black band.

Inhabits Indiana.

Eyes angularly contiguous above; front greenish yellow, with a black band; antennæ black; space between the antennæ and region of the stemmata, black; occiput dull yellowish; occipital interval tuberculiform, greenish-yellow; posterior upper canthus of the eyes black, passing in a hairy ridge to the top of the occipital tubercle; stethidium fuscous; two yellow oblique vittæ before; middle between the wings with a yellowish spot; pleura with two distant, parallel, oblique, yellow vittæ, margined with black; wings hyaline, immaculate ; stigma black; anal membrane white; abdomen blackish, a dorsal series of yellowish spear-shaped marks, those of the two posterior segments dilated, the last one quadrate; anal appendices not longer than the 
anal segment, mucronate; inferior process as broad at its tip as the tip of the abdomen, and widely more or less emarginated; beneath, first and second abdominal segments pale, the lateral tubercle rounded, unarmed; feet black.

Length about two and a half inches.

Var. A. Dorsal series of the abdomen none; a lateral series of dull yellowish, oblong, subtriangular spots.

The variety was sent to me by Dr. Harris. I have not seen the female.

$\uparrow+$ Eyes distant above.

9 As. fraterna. Wings immaculate; thorax yellowish, with brown lines; abdomen brown, with a yellow vitta; dilated at tip.

Inhabits U. S.

Length less than two inches.

s Head greenish-yellow; eyes distant above; labrum with an indented point in the middle; between the eyes a black band, including the stemmata and antennæ; thorax greenish-yellow, with three double fuscous vittæ; between the wings a greenish-yellow vitta; wings immaculate; costal nervure greenish; carpus fuscous small, the transverse line of its base passing obliquely across the second series of cellules; accessory membrane very small; abdomen dark fuscous, cylindrical, thicker at base, and much dilated at tip; a dorsal yellowish line, interrupted by the incisures, wider on the basal segment, and exhibiting a spot only on two of the dilated segments; anal appendices four, short, subulate; sides of the abdomen with a dilated 
yellowish vitta on the basal segment, on which is also a lateral tubercle; remaining segments with a spot on the base of each, those on the dilated segments are much larger, that on the terminal segment occupying all the side, yellow and conspicuous; pleura green-yellow, with two oblique, fuscous lines; feet fuscous; tibia with a dull green line; the dilated tip of the abdomen is very concave beneath.

o Tubercles of the basal segment of the abdomen. obsolete; abdomen at tip somewhat less dilated; anal appendices two.

Length two inches.

Common in June, on the banks of the Wabash.

It resembles forcipata, Fabr., closely, but the feet of that species are yellowish above; the dorsal line of the abdomen is capitate on each segment, and on the basal segment trilobate.

It belongs to the genus Gomphus, Leach.

10. A. stigmata. $\quad$ Body yellow; stemmata rather large; thorax with a double brown arcuated vitta before, each side of which is an abbreviated, oblique, brown line, and another brown line on the suture of the pleura; wings with a very slight tinge of yellowish, at their origin ferruginous; costal edge whitish, with two series of minute black points; stigma rather large, blackish ; tergum, each segment, excepting the basal and ultimate ones, with a longitudinal spot each side, contracted in the middle and not reaching the base; terminal processes conic, acute, not at all compressed; thighs with a brown line above towards the tip; tibia and voL. VIII.-1839. 
tarsi black-piceous; the former yellowish on the inner side; 'abdomen not remarkably clavated.

Length two inches.

This species resembles the fraterna, but it is much more yellowish, the stigma of the wings is about double the size, the markings differ. It also resembles unguiculata, Vanderlinden, but the stigma is much larger.

\section{LiBELLULA.}

1. L. hymenaa. Wings hyaline; posterior wings with the anal margin brown, with white nervures; anal membrane white, opaque.

Inhabits Indiana.

\& Vesicular front fulvous; stethidium dull yellowish-green; wings hyaline; stigmata small; posterior pair wider at base, the anal margin brown, particularly towards the anal angle, which, however, this color does not reach, neither does it attain to the origin of the wing, the nervures of this brown margin are yellowish-white; anal membrane opaque, pure white; scutel tricarinate; abdomen with a carinate line above, and on each side; second, third, fourth, and fifth segments with two transverse, elevated limes towards their middles; anal processes cylindrical, mucronate; feet blackish; anterior pairs of thighs greenish-white exteriorly; anterior pairs of tibiæ with a whitish line.

Length nearly two inches.

Readily distinguishable by the whitish nervures in the brown anal margin of the posterior wings, and the snow-white anal membrane. It seems to be allied to L. carolina. 
2. L. carotina, Linn. Basal fifth of the posterior wings fuscous.

Length two inches.

Drury's Ins., Vol. I., pl. 48, fig. 1. Ency. Meth., p. 565 .

3. L. transversa. Thorax with a white band before the wings, and another between the wings.

Inhabits Massachusetts.

¿ Body brownish; eyes contiguous above in a small part of their curvature; thorax with a yellowish-white band at the anterior base of the anterior wings, and a white band between the two pairs of wings, descending obliquely on the pleura, where it is yellow; wings hyaline ; basal costal cellula brown ; stigma slender, yellowish, not very obvious; anal membrane white; abdomen slender, wider near the tip; segments paler on the basal half; lateral carina none; anal processes lanceolate, slightly arcuated, exterior edge towards the tip minutely denticulate; inferior process nearly as long as the superior ones; tarsi blackish.

Length two inches.

Dr. Harris sent me a male specimen, I have not seen the female.

4. L. tenebrosa. Wings immaculate; body greenish-black, with yellow lateral marks on the trunk.

Inhabits Indiana.

o Eyes bright emerald green, in contact above; front brownish towards the mouth, near the antennæ bright green, above the antennæ brownish; mouth beneath yellowish; vertex brownish; thorax dark 
greenish, tinged towards the head and on the sides with vinaceous; an oblique yellowish line under each wing, and a yellowish spot each side behind; wings hyaline; stigma blackish; anal margin with a thick fuliginous nervure, tinged on its side with ferruginous; anal membrane blackish, whitish at base; abdomen greenish-black, immaculate, very slender behind the base, thickest at base, and fusiform beyond the middle; anal appendices arcuated, superior pair with a tooth on the superior middle, at tip abruptly incurved and truncate; feet immaculate.

Length over two inches.

5. L. lydia. Wings with a broad, brown band; and at base an abbreviated line.

L. lydia. Drury's Ins., Vol. I., pl. 47, fig. 4, Oliv. and Ency. Meth., p. 570.

This species agrees with the short description in Turton's Linn., of the trimaculata, Degeer, and I should certainly consider it the same species, if Olivier had not decided the trimaculata to be the same as the bifasciata, L.

6. L. bifasciata, Fabr. Wings with brown semifacia, tip and basal line.

I. pulchella, Drury, Vol. I., pl. 48, fig. 5.

L. Bifasciata, \& Fabr. Oliv. Enc. Meth., p. 561.

L. versicolor, Fabr. $\hat{s}$

L. trimaculata, Deg. Ins., Vol. III., pl. 26, fig. 2.

¿ Destitute of the white wing-spots; abdomen brownish-livid, with a lateral vitta, which is gray, and becomes gradually yellow to the tip; beneath 
with a yellow lateral vitta, being a continuation of the posterior line of the pleura, and becoming obsolete behind.

It is on the authority of Olivier, that I quote Degeer's trimaculata for this species, as I do not possess the work of the latter author.

7. L. ternaria. Wings with a fuscous line or spot at base; a spot or band in the middle and another near the tip.

Inhabits Massachusetts.

s Head, a black line between the antennæ; eyes above in contact by a curved line; posterior lateral canthus of the eyes with two yellow spots; pleura with two oblique lines; wings with a pale ferruginous vitta, extending from the base along the anterior submargin to the middle, thence along the margin to the tip, interrupted by the stigma, which is black; on the middle of the costal margin a fuscous spot, and from the stigma a fuscous band, which does not reach the tip; at base of the posterior wings, behind the vitta, is a rather large and conspicuous, irregular, fuscous spot, reticulated with whitish nervures; anal membrane white; marginal cellules ten or eleven between the middle and stigma; abdomen greenish-yellow at base, and black at tip, with a yellow lateral vitta; anal processes fusiform, black, subacute; inferior process hardly one-third as long as the others.

QThe spot of the middle of the wing is extended into a semifacia, and the subterminal band is more distinct; at the base of the posterior wings is a black, securiform line, one-fourth the length of the 
wing, behind which is a large, pale, ferruginous spot, reticulated with whitish nervures

Length one inch and seven-tenths.

At first sight resembles L. bifasciata, Fabr., but is quite different; the ultimate wing band is not terminal, the anal processes also are dissimilar.

I have not seen any other specimens than the sexes sent me by Dr. Harris for examination.

In some of its characters it resembles the $\mathrm{L}$. quadrimaculata, Linn., of Europe, but that has not the terminal wing bands.

8. L. leda. Wings at tip, point on the costal margin, and line at base, brown.

Inhabits U. S.

L. lydia, Drury's Ins., Vol. II., pl. 47, fig. 1, and Oliv. Ency. Meth., p. 570, No. 8.

Thorax brown, with a pale vitta; pleura greenish; wings with a blackish point in the middle of the costal margin, and oblong blackish carpus ; terminal half of the anterior margins and tip fuscous; a slender black line, at base, equal in length to the breadth of the body; abdomen with a broad, yellowish-rufous lateral vitta; anal segment remarkably short; on each posterior orbit of the eyes are two yellow spots.

Length about two inches.

Var. A. Fuscous tint on the anterior margin of of the wings obsolete, being only a very slight tinge of ferruginous.

Drury's figure represents this species very well, but the fuscous tips of the wings are generally broader, though sometimes altogether wanting. 
Olivier has two different species of the name of lydia, both of which he quotes from Drury. We have therefore changed the name of the present species.

9. L. quadrupla. Thorax with a whitish vitta; abdomen with a lateral, yellowish one; wings with a bicolored stigma, and basal blackish line.

Inhabits Massachusetts.

This insect very closely resembles L. leda, S. It differs, however, in being smaller, and in having the stigma larger, white, with a black tip. The male is destitute of the black wing tips, and like the female, has the exterior half of the costal margin tinged slightly with ferruginous. The anal processes are short, subcylindric, a little smaller at base, and beneath, towards the tip, minutely denticulated; at tip a small point.

The sexes were sent me by Dr. Harris.

Length from one inch and three-fifths to one inch and seven-tenths.

10. L. basalis. Wings fuscous on the basal half. Inhabits U. S.

s Body brownish-black; head immaculate, dark bluish; wings dark fuliginous opaque, on the basal half, beyond which is a broad, milk-white, almost opaque, band; stigma blackish; abdomen somewhat depressed, of equal diameter nearly to the tip, dusky, with a lateral dull yellowish vitta; beneath black-brown.

Length nearly two inches.

[In a note attached to this description by Mr. Say, 
is a reference to L. marginata, Degeer. Wings fuscous from the base nearly to the middle.

L. dimidiata, Fabr. V. Enc. Meth. refers to Seba, which is quite different. Said to be from Surinam, and is much smaller, to which species the above described insect seems to bear some resemblance in the arrangement of its colors.-ED.]

11. L. eponina. Upper wings bifasciate, and with a spot near the base; lower wings with a band and interrupted one, and subbasal line and spot.

Inhabits Pennsylvania and Indiana.

L. eponina, Drury, Vol. II., pl. 47, fig. 2. Oliv. Enc. Meth., p. 572, No. 19.

Wings pale ferruginous ; upper pair with a subbasal spot, band in the middle, and another band before the stigma, fuscous ; inferior wings with a corresponding band towards the tip, interrupted band in the middle, undulated, longitudinal line at the, base, and spot near the anal angle, fuscous; anal membrane white; stigma yellowish.

Length nearly one inch and a half.

A beautiful and strongly marked species.

12. L. acuta. Wings immaculate; body greenish-yellow; abdomen with the edges blackish.

Inhabits Mexico.

q Body greenish-yellow ; eyes approaching above, but hardly touching, the nearest parts not rounded, almost acute; orbits before and above with a black edge; stethidium immaculate; abdomen pale yellowish-brown, yellowish green at base; the acute longitudinal edges, above and each side, black; the 
transverse edges and a subbasal transverse line on each segment fuscous; venter also with a black line; feet black; thighs yellowish, with the spines black, and on the anterior pairs a line beneath.

Length one inch and three-fifths.

The quadrilineate abdomen, with the subacute proximate portion of the eyes distinguish this species; the abdominal lines are not dilated, but limited to the edge of the carinæ. The frontal vesicle is greenish-yellow, with a dark transverse line at the antennæ.

13. L. berenice. Frontal vesicle blue above; wings ferruginous at base.

Inhabits U. S.

L. berenice. Drury's Ins., Vol. I., pl. 48, fig. 3.

Front whitislı, steel-blue above; eyes obtuse above and connate; trunk brownish, with two greenish-yellow vittæ before, and with three oblique broad and obvious yellow lines each side under the wings; between the wings varied with blackish; wings immaculate, or with a tinge of ferruginous at their origin, particularly of the posterior pair, and on the middle; anal membrane blackish; stigma rather large and blackish; feet black; coxæ and trochanters yellow; inferior side of the anterior thighs yellow; abdomen with a dorsal black vitta, including the carina, and a lateral black vitta above the lateral carina; lateral carina black; these vittæ are more and more widely confluent at the sutures, towards the tip of the abdomen, which is: entirely black.

VOL. VIII. -1839 . 
Length from one inch and a half to one inch and three quarters.

It may be distinguished by the blue top of the frontal vesicle, and the ferruginous mark at base of the wings. 'The ferruginous cloud on' the middle of the wings is often altogether wanting. It also varies in having no abdominal vittæ, excepting a vestige at base. The blue color sometimes extends down the front. The abdomen is also sometimes blue, and the thorax sometimes black. Drury describes the abdomen of the female as yellow, with black annulations, and that of the male blue.

The inferior anal process is at least two-thirds the length of the superior ones, which are arcuated, with a tooth beneath near the tip, and at tip acute.

A specimen from Dr. Harris.

14. L. rubicundula. Abdomen sanguineous, with a lateral black vitta; wings pale ferruginous at base; anal appendices in the male with a tooth on the inferior middle.

Inhabits Indiana and Massachusetts.

Male. Eyes brown, in contact above; front greenish-white; mouth pale yellowish; thorax obscure brown, immaculate; between the wings a little tinged with dull sanguineous; wings with a very small ferruginous spot at base, not over onetenth of an inch in length, more evident on the inferior wings; stigma brown; about nine marginal cellules between the stigma and middle of the wings; tergum bright sanguineous, above carinate, immaculate, on each side a black line, which dilates 
towards the tip of each segment; anal appendices deflected, longer than the inferior conic one, mucronate, and with a strong tooth on the inferior middle; feet blackish, venter pale.

Length one inch and a half.

Variety. The ferruginous tinge of the base of the wings, extending to the middle; that of the superior pair chiefly on the anterior half of the wing; that of the inferior pair more obvious, much broader, extending nearly to the thinner margin.

Length one inch and two-fifths.

I have found many individuals of this species.

V. L. ferruginea. Enc. Meth., 565.

15. L. semicincta. Wings tinted on the basal half with pale ferruginous; anal processes with an angle beneath near the tip.

Inhabits Indiana and Massachusetts.

\& Antennæ black, with a blackish line between them; thorax brownish; pleura yellowish; wings hyaline; stigma rather small, its marginal nervures thick and black; basal half more or less tinted with pale ferruginous, particularly on the inferior wings; about seven marginal cellules between the middle and the stigma; anal membrane white; abdomen with a dorsal and lateral edge; paler at base, and with a lateral black line; anal processes deflected, rectilinear, cylindrical, with three or four minute denticulations beneath, an angle beneath near the tip, and the tip acute; inferior process extending nearly to the tip of the superior pair.

Length about one inch. 
Very much like a small specimen of rubicundula, S., but differs in several characters, particularly in the anal processes, and in the number of marginal cellules.

16. L. simplicicollis. Wings immaculate; stethidium yellowish; abdomen pale brown, a little varied with black.

Inhabits Indiana and Massachusetts.

\& Frontal vesicle pale greenish-yellow; a black band across at the antennæ; occiput and posterior orbits black, with yellow spots; eyes acute above, almost meeting; stethidium green-yellow, alternating with black at the superior base of the wings; wings immaculate; stigma fuscous; anal membrane narrow, black; feet black; thighs on their posterior side brownish; abdomen brownish, with slender incisural black lines and black edges to the carinæ; a black spot on each, excepting the three basal ones; beneath black; anal appendices very short, green, mucronate.

Length one inch and a half.

Of the male I have but one specimen, which is of a greenish-yellow color, with the sutures and abdominal spots contrasting strikingly with it.

Dr. Harris sent me a specimen for examination.

17. L. obsoleta. Wings with a submarginal series of six or eight brown spots.

Inhabits Indiana and Massachusetts.

Body dusky; wings hyaline; anterior marginal and submarginal longitudinal nervures dull yellowish; anterior wings with a submarginal series of 
small brownish spots from the base to the middle, the latter spot largest, transverse, and reaching the anterior edge ; posterior wings with six corresponding submarginal spots; a fuscous spot at the anal base of each wing; anal membrane black, with its basal half white; stigma dull yellowish; abdomen with the incisures black, a dorsal and lateral carinated line; feet with black spines.

Length about one inch and three-fifths.

The pleura and base of the abdomen are somewhat marked with brighter yellow. The brown spots of the anal base and the submarginal spots of the wings, are sometimes obsolete, or altogether wanting anal appendices $\hat{\delta}$ arcuated, unarmed; inferior process a little curved upward, over threefourths the length of the superior pair.

A female specimen sent me for examination by Dr. Harris has the spots of the anal base of the wings more obvious.

18. L. exusta. Wings with a fuscous spot at base; anal processes subequal.

Inhabits Massachusetts.

\& Body yellowish-brown, covered with a cinereous pubescence; a black line between the antennæ; eyes in contact by a small portion of their superior curvature; thorax above pale brownish with a yellowish-green vitta from the anterior wings forward; wings hyaline, very slightly tinted with yellowish; costal cellules, between the middle of the wing and the stigma, about twelve or thirteen; stigma yellowish; a fuscous longitudinal spot on the middle 
of the base of the superior wings as long as the width of the thorax; a larger, triangular, fuscous spot at the base of the inferior wings, a little longer than that of the upper wing; anal membrane white; abdomen with a dorsal and lateral edge; anal processes somewhat linear, a little arcuated, not narrowed at base, minutely denticulated towards the tip, which is acute; inferior process nearly as long as the others.

Length one inch and two-fifths.

I have not seen the female. From Dr. Harris.

19. L. cynosura. Posterior wings with a small fuscous spot at base; anal processes excurved.

Inhabits Massachusetts.

$\$$ Body brownish; head with a black line between the antennæ; tubercle above the antennæ large; eyes in contact above by a curved line; pleura pale greenish, a yellowish band beneath the anterior wings; wings hyaline; anteriors immaculate; about six costal cellules between the middle and the stigma, which is dull yellowish; posterior pair with the basal, costal, and subcostal cellules fuscous, and an irregular fuscous spot between them and the anal angle; anal membrane white; abdomen with a dorsal and lateral edge; on each side, near the base, a yellow spot, beyond which is a honey-yellow vitta; anal processes longer than the caudal and ultimate segment of the abdomen together, a little dilated and curved outwards towards the tip, which is rounded, abruptly narrowed beneath towards the base; inferior process two-thirds the length of the superior ones. 
Length one inch and a half.

Resembles exusta, but differs in the number of costal cellules and in the form and length of the anal processes.

It was sent to me by Dr. Harris.

20. L. tenera. Wings with an abbreviated band and subbasal spot.

Inhabits Indiana, Pennsylvania, and Massachusetts.

\&ody fuscous; frontal vesicle yellowish, brownish above; eyes contiguous above; thorax with two broad glaucous vittre before; pleura with two oblique, glaucous wide lines; wings hyaline, a fuscous, undulated band on the middle, not reaching the thinner margin; a fuscous spot midway between the band and base, somewhat larger on the posterior wings ; costal margin slightly tinted with ferruginous; stigma brown; anal membrane small, white; abdomen rather wide, second and third segments with a transverse, elevated line on their middle; feet yellowish.

Length nine-tenths of an inch.

It has some resemblance to L. varia, Linn., but . is a very different species. It is not uncommon, but is more limited than some other species to the immediate vicinity of ponds and sluggish waters.

21. L. tenuicincta. Small; wings ferruginous.

Inhabits U. S.

Body fuscous, small ; eyes meeting above; front yellow; above fuscous; thorax immaculate, somewhat hairy; pleura with about two yellow spots; 
wings entirely ferruginous ; stigma darker, reddish ; anal membrane small, blackish; feet dull yellowish; tergum with a very slender, bright yellow, transverse line at each incisure; anal appendices arcuated mucronate; inferior process nearly as long.

Length over four-fifths of an inch.

This small species is conimon in many parts of the Union, flying rather slowly over the surface of ponds, and, like other species, settling upon sticks and other objects that project above the surface.

V. L. obscura. Enc. Meth., 562.

Is it the male of tenera?

The following note, taken at the island of Sanipuxten, on the eastern shore of Maryland, I find. amongst my papers.

L. imbuta. of Abdomen red; segments black at tips; thorax green; frontal vesicle bluish; eyes darker.

\& Abdomen greenish; segments black at tips.

I have not observed this species in Indiana.

\section{Calepteryx, Leach.}

1. C. materna. Wings steel-blue, with a tinge of brown; a white, opaque, costal spot near the tip.

Libellula virgo, $\gamma$. Drury's Ins., Vol. I., pl. 48, fig. 2.

2. C. opaca. Bluish green, wings darker, immaculate.

Inhabits Massachusetts.

\& Body bluish-green, or blue, varied with green; 
beneath blackish; antenna, second and third joints equally long; wings subopaque, blackish-blue, with a tinge of brown, destitute of any costal spot; abdomen blue, segments at their tips greenish; feet black.

Length about one inch and seven-tenths.

Var.? Wings nearly hyaline, only tinged with the color.

For this species I am indebted to Dr. Harris.

3. C. equabilis. Blue and green; wings hyaline, a large blackish spot at tip.

Inhabits Massachusetts.

s Head and thorax green, tinged with blue; labrum blackish violaccous; antennæ, second joint rather longer than the third; wings hyaline, without any costal spot, a large fuliginous blackish spot at tip, occupying the fourth of the length on the anterior pair, and the third of the posterior pair; abdomen blue; beneath blackish, towards the tip greenish; anal processes curved inwards, and towards the tip a little downwards, of equal diameter, excepting that on the inner side they are a little dilated beyond the middle, upper side a little spinous; at tip obtuse; inferior processes two, rectilinear, cylindrical, a little shorter than the superior pair, dilated on their inner base; pectus and feet black.

Length less than two inches.

A female specimen, also sent me by Dr. Harris, may, perhaps, be of the same species, inasmuch as the wing-spots correspond, except in being paler; but the wings have an opaque white spot near the costal tip.

voL. VIII.-1S39. 


\section{LEstes, Leach.}

1. L. rectangularis. Wings divaricated; forceps acutely bidentate beneath.

Inhabits Indiana and Massachusetts.

¿ Body dull greenish, more or less tinged with cupreous; head above black, with a very slight coppery tinge; each side of the mouth yellow; labrum bluish yellow; mandibles piceous at tip; eyes (when recent) ultramarine; thorax with the dorsal suture and lateral vitta, varying from pale yellowish to verditer green; wings hyaline, cellules chiefly pentagonal; stigma blackish, its length nearly three times greater than its breadth; abdomen nearly as long again as the wings; tergum with the basal segments a little paler, darker at their tips, and with a hardly obvious whitish, interrupted band at their bases; ultimate segments much darker; anal segment with a longitudinal carina beyond the middle; forceps shorter than the two ultimate segments taken together, with two oblique, very acute teeth beneath; beyond the middle curved downward and inward, so as to become nearly perpendicular to the basal half; inferior processes almost reaching the incurved tip of the forceps; beneath pale, whitish, more or less tinged with yellowish-green.

Length over two inches.

q Abdomen much shorter than in the male; tergum with a more obvious cupreous color; feet (as in the male) pale yellowish, with two black lines on the thighs and one on the tibiæ. 
Length one inch and seven-tenths.

This species made its appearance here about the middle of August. It may at once be distinguished, when at rest, from the apicalis, by its divaricating wings. It resembles a South American species, which, not finding described, I have called undulata, * but the abdomen of that insect is much shorter.

2. L. basalis. Wings sanguineous at base.

Inhabits Missouri, Indiana, and Massachusetts.

$\delta$ Head cupreous ; thorax cupreous, with black sutures; pleura with yellowish, oblique lines; wings with quadrangular cellules and an oblong dusky carpus; basal fourth, bright sanguineous; pectus yellowish; feet black; tibiæ exteriorly dull yellow; abdomen steel-blue, with slender white incisures; beneath yellowish, with a black middle line; forceps arcuated, spinous above, with a large double tooth beneath; tip obtuse.

Length one inch and three-fourths.

\& Body green; head with a yellow, abbreviated line on the anterior orbits, yellow nasal margin and labrum; thorax with a lateral yellow vitta; wings tinted with yellowish-brown towards the base; car-

* L. undulata. Wings divaricated; forceps undulated at tip.

Inhabits South America.

\$ Body pale; head with a broad green band between the eyes; thorax with a double green vitta; wings hyaline; cellules chiefly pentagonal; stigma light brown; abdomen not one-third longer than the wings, coppery green above, whitish at tip ; forceps as long as the two preceding segments taken together, undulated at tip; on the basal half not dilated, and having beneath two remote tceth, of which the basal one is very obtuse, in the form of a lobe.

Length one inch and three-fifths. 
pus white; abdomen with a slender, longitudinal line, and slender basal annulation on each segment; beneath whitish, with a black line; feet black; thighs yellowish beneath; tibiæ yellowish above.

Length over one inch and three-fourths.

Of this fine species, Mr. Nuttall presented me two individuals which he obtained from Missouri. The bright sanguineous color of the wings in one sex terminates abruptly, and in the other the very pale yellowish-brown color of the same part gradually disappears towards the middle.

In the A. caia, Drury of South America, (A. Brightwelli, Kirby ?) the inferior pair of wings have a reddish spot at tip.

It is very abundant in some situations in Indiana, and is easily taken.

3. L. eurinus. Wings immaculate; forceps curved inward, bidentate.

Inhabits Massachusetts.

s Body blue, somewhat varied with greenish and violaceous ; pectus beneath yellowish; antennæ, second joint shorter than the third; labrum and each side of the mouth yellowish; thorax with a yellow vitta, behind bifid and divaricated; between the wings yellowish; pleura chiefly yellow; wings with a slight tinge of greenish-yellow; stigma blackish; abdomen blue, segments greenish at tip; beneath, a black vitta, and segments blackish behind; forceps curved inward, bidentate beneath; inferior processes conic, less than half as long as the forceps; feet black; thighs whitish beneath; tibix with a white line on the exterior side. 
Length one inch and nine-tenths.

The body is much shorter, and the wings larger than the rectangularis, S., which it resembles; the inferior anal processes also are shorter, and the superior pair not decurved so much. From Dr. Harris.

\section{Agrion.}

1. A. verticalis. Head green, blackish above; occiput with a bluish spot on each side.

Inhabits Indiana.

s Body above dark bluish, somewhat glaucous, with an obsolete brassy reflection; head light green ; above and behind black, with an obsolete brassy reflection; frontal projection black above, sometimes connected by this color with the color of the vertex ; eyes bright yellow-green, fuscous on the superior surface; occiput with a dilated pearlaceous blue or glaucous spot each side; hairs numerous and rather long; thorax with numerous, rather long hairs; a brassy vitta and lateral black lines; wings hyaline; cellules chiefly quadrangular; stigma short, rhomboidal, brownish ; tergum slightly pruinose, tips of the segments a little darker, and extreme base of the segments with an obsolete yellowish band; terminal segments a little darker and slightly iridescent; venter pale green or gray, with a black line; pectus and pleura greenish; feet greenish; thighs black above; tibiæ with a black line on the exterior side.

Length one inch.

q Body of a darker color than that of the female; the eyes are black above; the occipital spots are 
small and orbicular; the tergum is brassy-green, with a very narrow, white, interrupted band at base of each segment; two ultimate segments bright pearly blue; anal segment on the superior tip with an emarginate, slight elevation.

Length one inch.

This species is not abundant. I obtained several specimens in August.

2. A. hastata. Stigma almost detached from the margin, sanguineous.

Inhabits Indiana.

§ Head greenish; above dark metallic-greenish; eyes green, above blackish ; frontal projection blackish above; occiput with an orbicular glaucous dot each side; mouth yellowish; thorax brassy-greenish, sometimes tinged with blue; a slender pale line each side of the back; wings with chiefly rhomboidal cellules; stigma of the superiors obovate acute, connected with the edge of the wing only by a short petiole, sanguineous; stigma of the inferior wings rhomboidal, blackish; abdomen bright yellow; tergum with green hastate spots and lines; two or three ultimate segments immaculate; anal segment with an elevated, prominent spine-like process, bifid at tip; two very small, incurved, lateral hooks; venter with a slender, blackish line; pleura, pectus and feet pale green; thighs with a black line towards their tips, obsolete on the posterior pair.

Length over nine-tenths of an inch.

The edge of the superior wing, opposite to the stigma is a little convex and white. 
\& Head yellowish; above dark metallic-greenish; eyes above light brown, and beneath this color is an obsolete parallel line; occiput with the spots, connected by a paler line; thorax on each side with an obscure tinge of fulvous; stigma of the superior wings not separate from the edge, rhomboidal, yellowish-white; tergum green, tinged with dull fulvous each side before the middle; tail with two small angulated processes beneath, which do not extend beyond the extremity of the abdomen.

Var. a. Occiput fulvous; the fulvous color of the sides of the thorax and of the abdomen is more vivid and on the latter prevailing so that the green of the tergum is obsolete before the middle.

It is common in August, in meadows.

3. A. antennata. A glaucous occipital band; two basal joints of the antennæ subequal.

Inhabits Indiana.

$\hat{s}$ Body obscure bluish-green, somewhat metallic ; head green before; mouth yellow; vertex and occiput black, the latter with a glaucous band, clavate each side; eyes dark greenish, above blackish; antennæ with the two basal joints much thicker than the others, equal in length, the first cylindric, the second attenuated at base; thorax with a glaucous vitta each side of the back; wings hyaline; cellules chiefly quadrangular; stigma rhomboidal, not longer than broad; tergum with a glaucous band at base of each segment; the green color at tip extends upon the sides; venter glaucous, with a black line; pleura glaucous; pectus paler; feet whitish, with a 
broad black line on the thighs, and another on the tibiæ, excepting the posterior ones.

Length one inch and two-fifths.

This species is smaller than apicalis, and larger than either verticalis or hastata, Nob., and is distinguished from them by the elongation of the basal cylindric joint of the antennæ, being equal in length to the second joint.

4. A. apicalis. Two or three ultimate abdominal segments pearlaceous blue above.

Inhabits U. S.

Head pale brown; a black band on the vertex between the eyes, and sometimes two black circles; thorax pale brown, or bluish pearly, with black sutures; wings hyaline, with chiefly quadrangular cellules; carpus short, rhomboidal, brown, or dull whitish; nervures black; abdomen black-green; segments excepting the terminal three, with a dull whitish, basal annulus, from which proceeds a slender line, and on the side, a broader one of the same color, neither of which reach the tip of the segment; three ultimate segments dull yellowish; or cerulean pearlaceous above and on each side; pleura and pectus pale yellowish; feet pale yellow; thighs lineated with brown; tarsi with black incisures and extremity.

Length one inch and a half.

A very common species, remarkable, when lecent, by the color of the tip of the abdomen and of the thorax, which arrests the attention when the insect is on the wing. 
But it varies much in color. The vittr of the abdomen are more or less dilated, sometimes hardly visible; the head and thorax are, in some individuals pearlaceous-blue, and the ultimate abdominal segment varies from dull yellowish, with blackish lines, to a bright pearl-blue, sometimes dull-yellowish with a pearlaceous-blue lateral spot on each.

It is very common.

The female has two small angulated processes beneath the tail, which do not extend beyond the tip of the abdomen, the nails at their extremities are curved downwards; the hooks at the tip of the abdomen of the male are not obvious.

The description is from recent specimens. The fine blue color disappears in the cabinet specimen.

B Atis, Leach.

1. B. interpunctata. Whitish; head greenish; segments of the tergum black on the posterior edges. Inhabits Indiana.

Body yellowish-white, tinged with green; head rather prominent, yellow-green; vertex with a lateral black point; eyes with a longitudinal black line; stemmata distant, each with a black orbit; anterior one less than half the size of the others; seta of the antennæ black; front with a black angular line under the antennæ; neck distinct, separating the head from the trunk, with a black line each side; thorax somewhat brownish; wings on the anterior margin greenish, with black cross nervures, and a distinct, black, abbreviated, longitudinal

VoL. VIII.-1839. 
line on the middle, between the third and fourth nervures; feet greenish; anterior and intermediate pairs of thighs biannulate with blackish, posterior pair tipped with dusky; tergum with the posterior edge of the incisures black; setæ immaculate.

Length nearly three-tenths of an inch.

The small black spot on the middle of the costal margin is very obvious. The abdomen at tip is more or less obviously ferruginous.

2. B. arida. Brownish; posterior pairs of feet and setæ white.

Inhabits Indiana.

Body reddish-brown, with dusky incisures; head rather prominent, whitish, varied with ferruginous; vertex with a small black spot each side on the orbit; eyes rufous, with a whitish vitta; stemmata prominent, approximate; anterior one nearly as large as the others; wings immaculate, inferior pair more than one-third the length of the other; anterior tibiæ whitish, obscure at base and tip; posterior pairs of feet and setæ greenish-white; tergum with the posterior margins of the segments

Length two-fifths of an inch.

It occurs about the middle of June.

3. B. verticis. Yellowish-white; head and double thoracic vitta ferruginous.

Inhabits Indiana

Body yellowish-white; head sessile; vertex ferruginous; thorax with two ferruginous vittæ, confluent before, and becoming obsolete behind; wings with the nervures, except those of the margin, 
black; inferior wings not extending beyond the fourth abdominal segments; setæ hardly longer than the body, the incisures black; feet white; anterior thighs ferruginous at tip; anterior tibiæ at tip, and their tarsal incisures, fuscous.

Length over one-fourth of an inch, of the setæ over three-tenths.

Caught on the window in August.

4. B. obesa. Body short; wings blackish, with a hyaline spot, and numerous smaller ones.

Inhabits Indiana.

Body very short and robust, blackish livid; wings dark brown or blackish, with numerous small, transverse, hyaline spots, or abbreviated lines, and a large hyaline, very oblique, semifacia about the middle on the anal half; inferior pair, excepting on the apicial margin with numerous transverse, abbreviated, hyaline lines ; abdomen with a dull, rufous, livid margin to the segments; setæ very short, hairy, with black incisures; feet pale yellowish; incisures of the tarsi black.

Length over three-tenths of an inch.

This species is not common.

The wings are longer than the body, and the setæ not longer than the abdomen.

\section{Ephemera.}

E. hilaris. Minute, white; stethidium pale fulvous; abdomen with three lateral points.

Inhabits Indiana.

Body white; eyes black, double; stethidium pale 
fulvous; pleura and pectus with a few abbreviated dusky lines; wings two, ample, costal margin slightly dusky; abdomen depressed, with three brownish punctures on each side towards the tip; seta elongated.

Length one-tenth of an inch.

The smallest species I have seen. I caught several of them about the candle, on the evening of September 4th. They vary in having the brownish lines of the pleura and pectus obsolete, or altogether wanting.

\section{Formicaleo, Geoff.}

1. F. obsoletus. Antennæ white in the middle; abdomen with white bands.

Inhabits U. S.

Head dull whitish, with a broad, dark, honeyyellow band between the eyes; antennæ fuscous, middle fourth whitish; thorax dull whitish; wings hyaline; anterior pair with a few obsolete, small, brownish spots or transverse abbreviated lines, two of which on the posterior margin are oblique, and a somewhat larger one on the costal margin near the tip; posterior pair with fewer spots, about three or four subcostal distant ones, and a large one on the terminal fourth, and a less obvious apicial one; abdomen blackish, with a whitish band on each segment; beneath with a broad blackish vitta each side over the feet from the head to the abdomen; feet fuscous, posterior pair with a white annulus towards the tip, and at base and their tibia whitish. 
Length of body about one inch.

This species is rather common.

2. F.? grata. Wings at tip varied with black and pale carneous.

Inhabits Indiana.

Body blackish; head and thorax varied with yellowish; wings, on the apicial third, varied with flesh color, and a large trifarious, undulated, blackish mark; superior pair with a few blackish spots on the middle nervures, and on those of the anterior submargin; feet fuscous, with a yellowish line.

Length to the tip of the wings, about two inches. This beautiful species is very rare.

A specimen was presented to me by Mrs. Corson; it was taken at her residence, near Evansville, Indiana.

The palpi in the specimen are deficient.

\section{Chrysopa, Leach.}

C. oculata. Pea-green; head and thorax spotted; tarsi brownish.

Inhabits U. S.

Antennæ pale brownish; first joint white, with a sanguineous band at base above, second joint black; eyes golden; palpi alternately blàck and white; labrum with two dilated sanguineous vittæ; between the eye and the mouth is a black, angulated line; base of the antennæ enclosed by two black circles; which are tinged with sanguineous above; above each antenna are two blackish spots, of which the anterior ones are sometimes confluent with the 
circles of the antennæ; thorax with two series of three blackish spots in each, and two or three lateral spots; wings hyaline, iridescent, having the transverse nervures varied with black; tarsi pale brownish-yellow.

Length to the tip of the wings three-fifths of an inch.

This beautiful little insect is very common. When irritated, it diffuses a strong offensive odor, similar to that of human excrement. It is the analogue of the C. perla, L., with which I have hitherto confounded it, but, judging by Donovan's figure, it is never so large. Donovan says the perla stinks before a storm; our species has always that quality when irritated or alarmed. 
Summary of Meteorological Observations for 1836 ; made in Fayette co., Tennessee, by M. RHEA.

\begin{tabular}{|c|c|c|c|c|c|c|c|c|c|c|c|c|c|c|c|c|}
\hline \multirow[b]{2}{*}{ Mosths. } & \multicolumn{7}{|c|}{ Mean Temperature, Fah. } & & & \multirow[b]{2}{*}{ 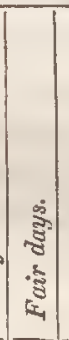 } & \multirow{2}{*}{\multicolumn{2}{|c|}{ 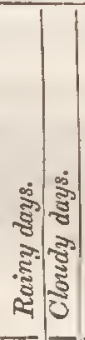 }} & \multirow{2}{*}{\multicolumn{2}{|c|}{ 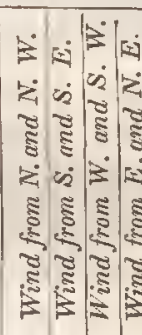 }} & \multirow{2}{*}{\multicolumn{2}{|c|}{ 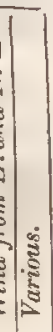 }} \\
\hline & ڤ્ & 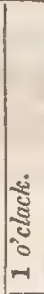 & 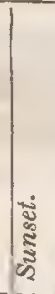 & 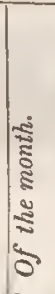 & 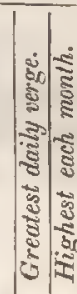 & 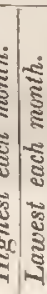 & 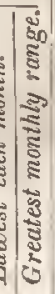 & & 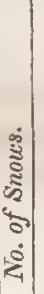 & & & & & & & \\
\hline $\begin{array}{l}\text { January, } \\
\text { February, } \\
\text { March, } \\
\text { April, } \\
\text { May, } \\
\text { June, } \\
\text { July, } \\
\text { August, } \\
\text { September, } \\
\text { October, } \\
\text { November, } \\
\text { December, }\end{array}$ & $\begin{array}{l}31 \\
33 \\
39 \\
57 \\
62 \frac{1}{2} \\
66 \\
71 \\
72 \\
68 \\
47 \\
37 \\
31\end{array}$ & $\begin{array}{l}38 \\
49 \\
56 \\
75 \\
83 \\
79 \\
84 \\
84 \\
81 \\
68 \\
51 \\
44\end{array}$ & $\begin{array}{l}35 \\
41 \\
45 \\
65 \frac{1}{4} \\
73 \frac{1}{4} \\
72 \\
78 \\
73 \\
74 \\
55 \\
44 \\
37\end{array}$ & $\begin{array}{l}34 \\
41 \\
46 \\
66 \\
73 \\
72 \frac{1}{3} \\
77 \\
76 \\
74 \\
55 \\
44 \\
37\end{array}$ & \begin{tabular}{l|l}
22 & 51 \\
32 & 67 \\
36 & 78 \\
34 & 89 \\
26 & 90 \\
$\frac{1}{3} 20$ & 88 \\
21 & 91 \\
26 & 93 \\
25 & 88 \\
40 & 78 \\
31 & 65 \\
32 & 57
\end{tabular} & $\begin{array}{l}1 \\
712 \\
820 \\
940 \\
05 \\
860 \\
16 \\
350 \\
84 \\
83 \\
52 \\
7\end{array}$ & $\begin{array}{l}8 \overline{43} \\
245 \\
058 \\
049 \\
040 \\
028 \\
526 \\
0 \mid 43 \\
444 \\
434 \\
414 \\
44 \\
651\end{array}$ & 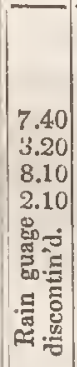 & $\begin{array}{l}1 \\
1\end{array}$ & $\begin{array}{l}14 \\
16 \\
13 \\
12 \\
12 \\
11 \\
15 \\
10 \\
14 \\
13 \\
12 \\
14\end{array}$ & \begin{tabular}{r|r}
11 & \\
6 & \\
12 & \\
6 & 1 \\
12 & \\
12 & \\
9 & \\
13 & 10 \\
7 & 1 \\
8 & 1 \\
9 &
\end{tabular} & \begin{tabular}{r|r}
6 & 7 \\
6 & 12 \\
7 & \\
7 & 9 \\
8 & \\
6 & 11 \\
10 \\
8
\end{tabular} & \begin{tabular}{rr|}
16 & 10 \\
14 & 4 \\
12 & 10 \\
4 & 15 \\
11 & 7 \\
13 & 5 \\
7 & 6 \\
8 & 10 \\
4 & 14 \\
13 & 3 \\
7 & \\
11 & 12
\end{tabular} & $\begin{array}{r}1 \\
7 \\
1 \\
1 \\
1 \\
7 \\
6 \\
3 \\
5 \\
5 \\
12 \\
4\end{array}$ & \begin{tabular}{l|l} 
& 1 \\
1 & \\
3 & \\
1 & 1 \\
1 &
\end{tabular} & $\begin{array}{r}12 \\
8 \\
6 \\
7 \\
10 \\
3\end{array}$ \\
\hline Of the year. & 51 & 66 & $58 \frac{1}{3}$ & $\frac{1}{3} 58 \frac{1}{3}$ & & & & & & 1541 & 1159 & 971 & & & & 87 \\
\hline n. 1837. & $36 \frac{2}{3}$ & & 35 & $35 \frac{9}{3}$ & $33 \mid 66$ & & & 1.60 & 3 & 12 & & & & & & 3 \\
\hline
\end{tabular}

Monthly range of barometer, 1.91 inches.

The months of January, February, March, and first part of April, were unusually wet and unpleasant, with strong winds from S. E. and N. W, and much thunder in February. This latter month was remarkable, in the early part of it, for excessive cold in East Tennessee. The thermometer then ranging here from 12 to 40 degrees at sunrise. Great rain fell here on the 12th and 25th of February, that on the latter from the $\mathbf{N}$. E., an uncommon 
occurrence. On the 9th of March, five inches of snow fell, and on the 17th, at 4 o'clock, A. M., a violent storm blew up from the $\mathbf{S}$. W., with one inch of rain. Throughout the latter part of April, May, June, July, August, and September, the weather was uniformly pleasant and favorable for agriculture. Frequent showers from thunder clouds, with brisk winds, occurred, particularly in June, some of which were very heavy. The latter part of July, and the whole month of August, were remarkable for a deleterious atmosphere, which produced much bilious disease, and nervous derangement. The first white frost occurred on the last night of September. The first ice was seen on the morning of the 5th October. The months of October and November, although cool, were uncommonly pleasant and favorable for gathering crops of corn, cotton, \&c. The health of the country was also good.

During the month of December, the weather was attended with great and sudden changes. Seven of which, from warm to cold, occurred within the month. The thermometer fell from 56 degrees at noon, on the 20th, to 6 degrees at 6 o'clock., A. M., of the 21st, a period of 18 hours.

With the beginning of the new year, the weather assumed a more mild and uniform tenor, and remained so during the whole month of January. The greatest proportion of the weather was cloudy, but rains were few and very slight. Three light snows fell, which soon disappeared. General good health prevailed. 
Aurora Boreatis.

This phenomena, so unusual in southern latitudes, was presented here on the night of the 25th of January past, with a grandeur and effulgence which, perhaps, surpassed any appearance of the kind ever witnessed as far south as the 35th degree.

The aurora of the 17th of November, 1835, is well recollected by the inhabitants of this country as a phenomena entirely unusual. The corruscations of light at that time were confined mostly to the neighborhood of the northern horizon, and were but imperfectly defined in their outlines. The color of the luminous clouds was but little varied, exhibiting a pale colored appearance. The changes were slow, and hardly discernible.

The aurora, of the 25th of January, presented much of the quick and beautiful changes peculiar to this phenomena in the high latitudes. The morning was cloudy until 9 o'clock. The day afterwards was clear and very fine, a gentle wind blew from the west. The thermometer stood at 27 degrees at sunrise, and 32 at sunset. Barometer 29.70 inches at sunrise, and 29.40 at sunset. As daylight declined, a bright, pale colored light was observed in the northern horizon, surmounted by a broad, irregular, crimson colored arch, extending twenty or more degrees on each side of the pole, from the vertex of which pale luminous, transparent pillars rose perpendicularly, reaching nearly to the zenith. The pillars seemed continually to be melting away into thin, red, transparent clouds, which VOL. VIII. -1839 . 
moved off with considerable velocity to the east and west. At 9 o'clock, when the moon rose, the arch had entirely disappeared, and the horizon, in that direction, wore an uncommonly dark appearance, except where illuminated by the pale colored pillars, which still continued to shoot up towards the zenith, fringed, as before, with red clouds. Borders of transparent red clouds were then gathered in the north-east and north-west, the former of which was particularly red and luminous, and remained stationary for some hours, giving out light, flying clouds of the same color, which soon disappeared. As the night advanced, the light continued to grow dimmer and more confused in form and color, until the whole disappeared entirely.

The weather, for some time previously, had been uncommonly pleasant for the season, except a slight snow on the morning of the 24th. On the day succeeding the aurora, the weather was fine. The thermometer stood at 22 degrees at sunrise, and 34 at sunset. The barometer at 29.54 inches at sunrise, and 29.10 at sunset. No rain fell until the 7 th of February, except a slight shower on the 30th. The weather remained fair and unusually pleasant and warm, with brisk winds from the S. and S. E. On the 3d of February, hazel bushes were in bloom, and doves and frogs were heard singing; the thermometer for some days ranging from 30 to 60 degrees. 
Description of five New Fossils, of the Older Pliocene Formation of Maryland and North Carolina. By Wm. Wagner.

Read January 2d, 1838.

Pecten Marylandicus. Pl. 1, fig. 1.

Shell ovate, compressed ; ribs numerous, consisting of narrow, nearly smooth striæ, disposed in pairs ; interstitial spaces each with a carinated line; ears unequal; inferior valve very slightly convex; ribs similar to those of the opposite valve; inner margin of the valve with profoundly elevated lines.

Locality. Mehering river, North Carolina. This Pecten is allied to Pecten Madisonius, Say, but can readily be distinguished by its want of broad, elevated ribs, and a surface destitute of scales; several specimens of SPIRoRbus nautiloides, Lam., are attached to the surface of the superior valve.

\section{Venus inoceriformis. Pl. 1, fig. 2.}

Shell oblique, suborbicular, thin and fragile, ventricose; disks with unequal, concentric undulations, forming prominent angulated carinæ; concentric striæ numerous, prominent; beaks prominent; no distinct lunule; cardinal teeth lamellar.

Locality. Banks of St. Mary's river, Maryland. This beautiful Venus is very similar in the exterior to some species of Inoceramus, which character has suggested the name. One specimen alone has 
hitherto been found; this I obtained on a visit to Porto Bello, on St. Mary's river, Maryland.

Panopea Goldfussii. Pl. 1, fig. 3.

Shell oblong, subovate, ventricose; disks with concentric, unequal, shallow grooves; lines of growth coarse and prominent; anterior extremity slightly gaping; anterior margin rounded, anterior dorsal margin elevated; posterior side narrowed, somewhat produced, not reflected; posterior dorsal margin nearly rectilinear; cardinal teeth obliquely compressed, united at base to the nympha, short and not very prominent.

Locality. Mehering river, North Carolina. Allied to Panopea reflexa, Say, from which it differs in being proportionally more elongated, and without reflected margin, in being nearly closed anteriorly, and in having a straight dorsal line.

\section{Mrsia nucleiformis. Pl. 1, fig. 4.}

Shell suborbicular, ventricose, lines of growth very distinct on the inferior half of the disk; posterior margin direct.

Locality. Mehering river, North Carolina.

\section{Trocilus eboreus. Pl. 1, fig. 5.}

Shell smooth and slightly polished; spire short, conical; whirls flattened laterally, margined above by a very obtuse obsolete carina; spriral lines ob- 
solete; periphery sharply angulated, subcarinated; base flattened; subumbilicated columella grooved; aperture half the length of the shell. land.

Locality. Banks of the Patuxent river, Mary-

This species is remarkable for it smooth surface, and white, ivory-like appearance. It is rare.

A few Facts in relation to the Identity of the Red and Motlled Owls, \&c. By Ezra Miciener, M. D.

Read July 3d, 1838.

IT is an extraordinary fact that, up to the present time, the identity of the red and mottled owls should not have been satisfactorily settled. Notwithstanding the imposing authorities of Buonaparte, Audubon, and Nuttall, and their extensive opportunities for observation, and the very general concurrence of other able ornithologists on the affirmative side of the question, I still think there is cause to doubt the correctness of their conclusion. I have long doubted the identity of those birds, and within the last four years have several times invited the attention of individual members of the Academy to the subject.

My observations, indeed, removed any doubt in the case, and I unhesitatingly restored Wilson's 
specific name-ncevia-to the gray or mottled owl in my collection four years ago.

I am indebted to a friend for extracts from a Boston journal, in which Samuel Cabot, jr., contends for the identity of the two birds, but reverses the priority of age, so as to make the mottled the young of the red owl. His testimony, however, does not change my opinion as already expressed, that the red and mottled owls are specifically distinct.

I will briefly state the facts on which this opinion is founded.

In early life, I have sometimes seen broods of young screech-owls accompanied by their parents after leaving the nest. I have seen them both red and gray, but never saw the two colors in company, nor have I ever heard any of my friends mention such an occurrence.

In the spring of 1833 , some boys brought me two very young screech-owls, whose only covering was a grayish-white down. One of them was much less than the other, and soon died. The survivor began to put forth feathers in a few days, all of which came from the sheaths red. I had not an opportunity of seeing the parent bird, but the boys said that they had several times caught her on the nest, and that she was "as red as a fox." The conclusion, then, is certain, that red parents have red young. Unfortunately, my bird died when about six months old.

During the summer of that year I commenced forming a cabinet of birds, in which I was assisted by my kind friend, J. K. Townsend, who was wit- 
ness to, and can attest the truth of most of the facts which I have to state.

Sixth mo. 17th, 1833.-Found a company of four gray or mottled owls, two of which were in full plumage, the other two were young. I killed one of the old, and the two young ones. 'The former, and one of the latter, are now in my cabinet; the other, I believe, is still in the possession of John $\mathrm{K}$. Townsend. These birds, both old and young, were unequivocally mottled owls, without the slightest shade of red about them. The young ones were, moreover, about the size and age, and in the same state of plumage with my living red owl, affording an excellent opportunity for comparison. In the one, every feather was more or less red; in the other, no shade of red appeared. The mottled parent, therefore, has mottled young. Thus both the old and the young are sometimes red, sometimes mottled.

The conclusion is, therefore, evident, either that the color of both old and young is variable and uncertain, or that they are specifically distinct. But with the single exception of Cabot's birds, the young appear to partake of the color of the parent; nor is there any analogy among the owls to sustain a different opinion. Hence I have adopted the opinion that they are essentially different.

With the exception of the young birds, I have not had an opportunity to compare recent specimens, and am unable to indicate any specific characters by which they ean be distinguished, except color. But as this appears to be permanent in both 
old and young, it ought to be deemed sufficient. I believe that the mottled bird may be rather smaller than the red one, as noticed by Cabot, but of this I am not certain. A careful comparison would, probably, discover other distinguishing characters.

I will conclude with a few facts in relation to the habits of owls.

My pet red owl drank frequently, and was accustomed to wash every day in a basin of cold water, during the heat of summer.

It has been stated that one of the young owls was much less than the other whon taken from the nest. It appeared to be very young, would not feed, and soon died. At the time, I was at a loss to account for the difference. On a subsequent occasion, I found a long-eared owl on her nest, and shot her. The nest contained four young birds and one egg. The birds were all of different sizes, and evidently of ages corresponding. The larger one was at least twice the size of the smallcr. The chick in the egg was alive, and nearly ready to be excluded from the shell. In both these cases, therefore, it appears that the eggs must have been hatched at different times,-perhaps in the order of succession in which they were laid.

I think this curious circumstance may be explained by supposing that the parent continues to sit on the nest, at least during the day, from the time she commences laying her eggs.

It would be curious to know whether this mode of incubation may not be common to all the owls, or at least to those of a nocturnal character. 
Description of several New Species of American Quadrupeds. By Rev. J. Bachman, of Charleston, S. C.

\section{Rear August 7th, 1838.}

Mr. J. K. Townsend having placed at my disposal, for examination and description, his valuable collection of quadrupeds, obtained in his recent laborious and perilous journeys over the Rocky Mountains, and along the western borders of our continent, I proceed to give short descriptions of such as appear to be undescribed, or have been incorrectly referred to other known species. As the different species included under the genera to which they belong, are not generally described with the accuracy required in the present state of the science, I commenced preparing detailed descriptions of all the species. Although these papers are nearly ready for publication, yet the drawings are not completed, and as these are very important in many species, I have concluded to defer submitting them to the Society for a few months. In the mean time, as an act of justice to their discoverer, I proceed to establish the species at once; reserving a more careful and scientific description to a future, but I hope not distant period. As I have not had an opportunity of consulting the recent scientific journals of Europe, it is possible that some of our enterprising naturalists abroad may have already published the voL. viII.-1839. 
species here described; if so, I shall be content that my names shall stand as synonyms.

1. Scalops Townsendii. Townseud's Shrew Mole.

Scalops canadensis, Richardson. Fauna Boreali Americana, p. 9.

This species, first described by Dr. Richardson, was incorrectly referred to the common shrew mole of the United States. Its size and dentition are sufficient evidences of its being a new and distinct species; which, on account of the number and arrangement of its teeth, will either require the characters of the genus to be enlarged, or that it be placed under a new sub-genus. A specimen of this quadruped was kindly presented to me by $\mathrm{Mr}$. Nuttall, who requested that, in case it should prove a distinct species, it might be given under the above name. I subsequently received from Mr. Townsend another specimen, a little larger in size, which I presume to be a mere variety, although very singularly marked.

Description of Mr. Nuttall's Specimen.

Length of the head and body, 7 inches 6 lines.

" " tail, 1 " 6 "

Breadth of the fore palm, 7 "

Dental formula.-Incis. $\frac{2}{4}$. False molars, $\frac{12}{12}$. True molars, $\frac{8}{6}, 44$.

The body is thick and cylindrical, shaped like the shrew mole of the United States. The whole upper and under surface is of a dark color, in most 
lights appearing black. The hair, when blown aside, exhibits a grayish-black color from the roots to near the tips. The tail is slightly clothed with short, strong bristles.

The specimen brought by Mr. Townsend is thicker, and about an inch longer. It has a white stripe, about two lines wide, commencing under the chin, and running in a somewhat irregular line along the under surface of the body to within an inch and a half of the insertion of the tail ; there is also a white streak commencing on the forehead, and extending along the snout.

The specimen of Mr. Townsend is labelled "Banks of the Columbia river, May 9th, 1835."

The body of the Scatops canadensis is from five to five and a half inches in length. Its color, although occasionally variable, is uniformly much lighter than that of the present species. The adult of the former also has thirty-six tecth, as I have ascertained from an examination of many specimens, and in this respect their characters are correctly given by F. Cuvier. From a skull of the adult $\mathrm{S}$. canadensis, Dr. Harlan evidently formed his S. Pennsylvanica, which, I think, cannot be continued as a true species. The specimen which he described as the Scalops canadensis, as well as those of Desmarest and Griffith, were young animals, which all present the same deficiency of teeth, as also the wide edentate spaces which they observed between the incisors and grinders. About one-half of the numerous specimens now before me, which I 
know to be young animals have similar dental arrangements.

\section{Arvicola Tonnsendii. Townsend's Meadow Mouse.}

Body cylindrical; head rather small; whiskers nearly all white, intermingled with a few black hairs; eyes small; teeth large, yellow; ears large, broad, extending a little beyond the fur; feet of moderate size; toes like the rest of this genus; thumb protected by a rather short, acute nail; fur on the back about three lines long, much shorter beneath; tail scaly, sparingly covered with soft, brown hair, a few white hairs at its extremity ; feet clothed to the nails with short, brown, adpressed hairs; claws brown; fur above lead color from the roots to near the tips, which are dark brown; beneath cinereous.

Length of head and body, 6 inches 0 lines.

$$
\text { "s tail, }
$$

Fore feet to point of nails,

From heel to point of nail,

Breadth of ear,

2 "6 6 "

0 " 9 "

1 " 0 "

0 " 5 "

Of this species, which was a male, obtained by Mr. Townsend on the Columbia river, on the 21st July, 1835, I can find no description in Richardson.

3. Arvicola oregoni. The Oregon Meadow Mouse.

This diminutive species is another of the discoveries of $\mathrm{Mr}$. Townsend. 
Head of moderate size; body slender; eyes very small for this genus ; ears nearly naked, concealed by the fur; feet small; whiskers the length of the head, white and black, the latter predominating; color above, a shade lighter than that of the former species, inclining a little to hoary brown; ash colored beneath; a very minute, blunt, thumb nail on the fore foot.

Length of the head and body, 3 inches 0 lines.

$$
\text { " " tail, } 1 \text { " } 2 \text { " }
$$

The above was an old male, captured at the Columbia river, November 2d, 1836.

\section{Sperirophilus Townsendii. Townsend's Marmot.}

Spermophilus guttatus, Richardson.

This singularly marked and, I conceive, new species, is another of the discoveries of our indefatigable countryman, Mr. Townsend. In a letter to me, he states, "That it inhabits, in the summer, the prairies near the Walla-walla; is rather common. It becomes excessively fat, and is eaten by the Indians. It disappears in August, and reappears early in spring, in a very attenuated state."

The body is long, and rather slender; head of a moderate size; nose slightly obtuse; ears short, scarcely a line in height; nails slender, compressed, and slightly arched; the thumb protected by an acute and prominent nail; the second claw in the fore foot, as in all the species of this genus, is longest, and not the third, as in the squirrels. Cheek pouches not large; tail thickly clothed with fur, 
and in the dried specimen appears much flattened; the fur is soft, smooth, and lustrous.

There is a line of white above and beneath the eye-brows. The fur on the whole of the upper surface, is for one-fourth of its length from the roots of a nearly black color, then a broad line of silvergray, then a narrow line of dark brown, edged with yellowish-white, with a few black hairs interspersed, giving it a brownish-gray appearance. On the under surface, where the hair is a little longer than on the back, it is black at the roots, and cinereous at the points; on the forehead and nose it is slightly tinged with brown. The line of separation between the colors of the upper and the under surface, exists high up along the sides, and is very distinctly drawn. The tail, on the upper surface, is the color of the back; slightly tinged with brown beneath; the teeth are white.

Length of the head and body, 8 inches 9 lines.

$\begin{array}{llllrl}\text { " } & 1 & \text { " } & 10 & \text { " } \\ \text { " } & \text { tail, (vertebræ, } & 1 & \text { " } & 0 & \text { " } \\ \text { " including fur, } & 1 & \text { " } & 6 & \text { " }\end{array}$

Length from heel to end of middle

hind claw,

1 " 4 "

This species bears some resemblance to the tawny marmot, (S. Richardsonii, ) with which I have compared it, as also to the American souslik, (ARcTomys. Spermophilus guttatus, Richardson,) but is evidently distinct from either. 


\section{Sciurus Douglassii, Bennett. S. Tonnsendii, nob. Douglass's Squirrel.}

This species, in the form of its body, is not very unlike the Sciurus hudsonicus; its ears and tail, however, are proportionably much shorter; it is about a fourth larger, and, in its markings, differs widely from any other known species.

Head considerably broader than that of the ScIURUs hudsonicus; nose less elongated, and blunter ; body long and slender; ears rather small, nearly rounded, slightly tufted posteriorly. As usual in this genus, the third inner toe is the longest, and . not the second, as in the Spermophitus.

Color.-The whiskers, which are the length of the head, are black. The fur, which is soft and lustrous, is, on the back, from the roots to near the points, plumbeous, tipped with brownish-gray, with a few lighter colored hairs interspersed, giving it a dark brown appearance; when closely examined, it has the appearance of being thickly sprinkled with minute points of rust color on a black ground. The tail, which is distichous, but not broad, is for threefourths of an inch of the color of the back; in the middle, the fur is plumbeous at the roots, then irregular markings of brown and black, tipped with soiled white, giving it a hoary appearance; on the extremity of the tail the hairs are black from the roots, tipped with light brown. The inner sides of the extremities, and the outer surface of the feet, together with the throat and mouth, and a line 
above and under the eye, are bright buff. The colors on the upper and under parts are separated by a line of black, commencing at the shoulders and running along the flanks to the thighs. It is widest in the middle, about three lines, and tapers off to a point. The hairs, which project beyond the outer margins of the ears, and forming a slight tuft, are dark brown, and, in some specimens, black.

Length from point of nose to the

insertion of the tail,

Length of tail, (vertebræ,)

" " including fur, 6 " 6 "

Height of ear posteriorly,

Sole and middle hind claw,

0 " 64 " 6

1 " ' 11 "

Several specimens of the above squirrel, exhibiting scarcely any variation in color, were obtained by Mr. Townsend on the Columbia river. He remarks in his notes: "This is a very plentiful species, inhabits the pine trees in this neighborhood, and, like our common Carolina, lays in a great quantity of food for consumption during the winter months. This food consists of the cone of the pine, with a few acorns. Late in autumn, it may be seen very busy in the tops of the trees, throwing down its winter stock, after which, assisted by its mate, he gathers it in, and stores it away in readiness for his long incarceration."

6. Scrurus Richardsonii. Columbia Pine Squirrel.

Small Brown Squirrel, Lewis \& Clarke, Vol. III., p. 37.

Sciurus hudsonicus, var. (Columbia Pine Squirrel, Richardson.)

This small species was first noticed by Lewis 
and Clarke, who deposited a specimen in the Philadelphia Museum, where it still exists. I have compared it with a specimen brought by Mr. Townsend, and find them identical. Richardson, who appears not to have seen it, supposes it to be a mere variety of the Sciurus hudsonicus. On the contrary, Mr. Townsend says in his notes: "It is evidently a distinct species; its habits are very different from those of the Sciurus hudsonicus. It frequents the pine trees in the high range of the Rocky Mountains, west of the great chain, feeding upon the seeds contained in the cones. These seeds are large and white, and contain a good deal of nutriment. The Indians eat a great quantity of them, and esteem them good. The note of this squirrel is a loud, jarring chatter, very different from the voice of $\mathbf{S}$. hudsonicus. It is not at all shy, frequently coming down to the foot of the tree to reconnoitre the passenger, and scolding at him vociferously. It is, I think, a scarce species."

The difference between these two species can be detected at a glance, by comparing the specimens. The present species, in addition to its being about a fourth smaller, (the size of the Sclurus (Tamias) lysteri,) has less of the reddish brown on the upper surface, and may be always distinguished from the other by the blackness of its tail at its extremity.

The body of this most diminutive of all the known species of genuine squirrel in North America, is short, and does not present that appearance of lightness and agility which distinguishes the $\mathbf{S}$. hudsonicus. Head large, less elongated, and nose a VOL. VIII.--1839. 
little blunter than S. hudsonicus; ears short; feet of moderate size; the third toe on the fore foot but slightly longer than the second. The claws are compressed, hooked, and acute; tail shorter than the body; the thumb nail is broad, flat, and blunt.

The fur on the back is dark plumbeous from the roots, tipped with rusty brown and black, giving it a rusty gray appearance. It is less rufous than the S. hudsonicus, and lighter colored than the S. Townsendii. The feet, on their upper surface, are rufous; on the shoulders, forehead, ears, and along the thighs, there is a slight tinge of the same color. The whiskers, which are a little longer than the head, are black; the teeth yellowish-white. The whole of the under surface, as well as a line around the eyes, and a small patch above the nostrils, smoke-gray. The tail, for about one-half its length, presents on the upper surface a dark rufous appearance, many of the hairs being nearly black, pointed with light rufous. At the extremity of the tail, for about an inch in length, the hairs are black, a few of them slightly tipped with rufous. The hind feet, from the heels to the palms, are thickly clothed with short, adpressed, light colored hairs ; the palms are naked. The sides are marked by a line of black, commencing at the shoulder, and terminating abruptly on the flanks; it is about two inches in length and four lines wide.

Length of head and body, $\quad 6$ inches 2 lines.

$\begin{array}{llllll}\text { " tail, (vertebræ, } & 3 & \text { " } & 6 & \text { " } \\ \text { " } & \text { " including fur, } & 5 & \text { " } & 0 & \text { " } \\ \text { " ears pesteriorly, } & 0 & \text { " } & 3 & \text { " }\end{array}$


Length of ears, including fur,

Sole and middle hind claw, 0 " 9 "

0 inches 5 lines. labelled "Rocky Mountains, August 12th, 1834."

\section{Sclurus lanuginosus. Downy Squirrel.}

A singular and beautiful little quadruped, to which I have conceived the above name appropriate, was sent to me with the collection of Mr. Townsend. He states in his letter, "Of this animal I know nothing; it was killed on the coast near Sitka, and given me by my friend, W. F. Tolmie, Esq., Surgeon of the Honorable Hudson's Bay Company."

The head is broader than S. hudsonicus, and the forehead much arched; the ears short and oval; whiskers longer than the head; feet and toes short; thumb armed with a broad, flat nail; nails slender, compressed and acute; the third on the fore feet is the longest, as in the squirrels. The tail, which bears some resemblance to that of the flying squirrel, is composed of hairs a little coarser than those of the back, and much shorter than the body. On the fore feet the palms are nearly naked, the under surface of the toes being only partially covered with hair, but on the hind feet, the under surface from the heel even to the extremity of the nails, is thickly clothed with soft, short hairs.

The fur is softer, and more downy, than that of any other of our species, and the whole covering of the animal indicates it to be a native of a cold region.

The teeth are dark orange; whiskers brown; the 
fur on the back, from the roots to near the extremities, light plumbeous, tipped with light chestnutbrown, on the sides with silver-gray; there is a broad line of white around the eyes; a spot of white on the hind part of the head, a little in advance of the anterior portion of the ears; the nose is white, which color extends along the forehead till above the eyes, where it is gradually blended with the colors on the back; the whole of the under surface, including the feet and the inner surface of the legs, pure white. In the tail the colors are irregularly blended with markings of black, light brown, and white, scarcely two hairs being uniform in color. In general, it may be said, that the tail, when examined without reference to individual hairs, is light ash at the roots of the hairs; then a broad, but not well defined line of light rufous, then dark brown, and tipped with rufous and smoke-gray.

Length of head and body,

7 inches 11 lines.

" tail, (vertebræ,

" " including fur,

Palm and middle fore claw,

Sole and middle hind claw,

Length of fur on the back,

4 " 8 "

6 " 0 "

1 " 0 "

" " at the tip of the tail,

Height of ear measured posteriorly,

1 " 9 "

0 " 7 "

Distance between the orbits,

\section{Tamias Tonnsendii. Townsend's Ground Squirrel.}

This species bears some resemblance to our common ground squirrel of the middle and northern. 
states, (S. lysteri,) it differs from it, however, in its larger size, longer tail, and several other striking particulars.

The body is stouter than that of the former species, the head broader, the nose more obtuse, and the tail nearly double the length. In the arrangement of the teeth and toes, this species does not differ widely from the S. (Tamias) lysteri, except that they are more robust. The teeth are dark orange; whiskers, which are a little shorter than the head, black; a line of fawn color, commencing at the nostrils, runs over the eye brows, and termi nates a little beyond them in a point of lighter color; a patch of similar color commences under the eye-lids, and running along the cheeks terminates at the ear.

There is a line of dark brown commencing at the termination of the nose, where it forms a point, and, bordering the fawn color above, is gradually blended with the lighter colors of the head. The ears, which are of moderate size, and ovate, are on the upper margins of the inner surface partially clothed with a few short, brown hairs; the outer surface is thickly clothed with fur, brown on the anterior parts, with a patch of white covering about one-fourth of the ear on the posterior portions. Behind the ear, there is a slight marking of cinereous, of about six lines in length, terminating near the shoulder. A line of black commences on the hind part of the head, runs over the centre of the back, where it spreads out to the width of four lines, and terminates in a point at the insertion of the tail; a line 
of similar color commences at the shoulders, and running parallel, terminates a little beyond the hips; another, but narrower and shorter line, of the same color, runs parallel with this, low down on the sides, giving it five black stripes. The head and back are light yellowish-brown, presenting on the upper surface a dusky-ochre color. It has not the whitish stripes on the sides, nor the rufous color on the hips, which are so conspicuous in the Sciurds (Tamias) lysteri. On the throat, belly, and inner parts of the legs and thighs, the color is light cinereous; there is no line of separation between the colors of the back and belly. The tail, which is not bushy, is on the upper surface grayishblack, having a hoary appearance. Underneath it is reddish-brown for two-thirds of its breadth, then a narrow line of black, tipped with light ash. The nails are brown.

Length of the head and body, 6 inches 9 lines.

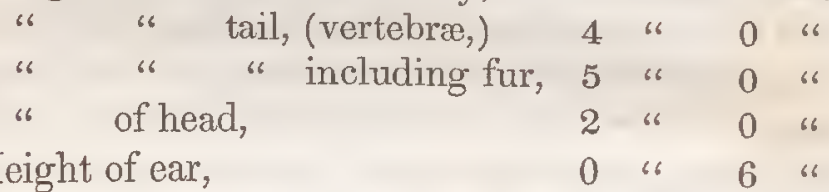

Length of heel to middle claw of

the hind foot,

1 "6 6 " 6

Mr. Townsend states in his notes: "This pretty little fellow, so much resembling our common striatus, is quite common. It lives in holes in the ground; running over your foot as you traverse the woods. It frequently perches itself upon a log or stump, and keeps up a continual clucking, whiclı is usually answered by another at some distance, 
for a considerable time. Their note so much resembles that of the dusky grouse, (T. obscurus,).that I have more than once been deceived by it.

\section{Tamias minimus. Least Ground Squirrel.}

This diminutive and beautiful species of tamias, not half the size of the common ground squirrel, is another of the discoveries of Mr. Townsend. He says in his notes: "It is found very plentiful along the banks of the Rio Colorado, but, I think, does not inhabit a very extensive range, as I never saw it after leaving this river. It keeps almost constantly among heaps of stones, on the tops of which it often perches, extending its long tail over its back, and curving it over in front of its head. At such times it emits a lively, garrulous note, like the squeaking of a young puppy, but, if approached, darts off with astonishing swiftness, carrying the tail level with the ground, and almost eluding the eye by the activity of its motions, and conceals itself under some jutting rock, or in the interstices of a stone heap, until the intruder has passed." Length of head and body, 3 inches 9 lines.

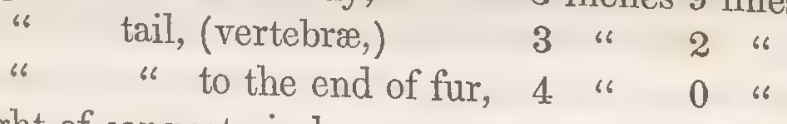

Height of ear posteriorly, $\quad 0$ " $\quad 2 \frac{1}{2}$ " Length of head, Of heel to end of middle claw, 1 " 3 "

The head is rather small; the nose very sharp pointed; claws moderately curved, compressed, 
acute, and dark brown. 'There is, as in all the species of this genus, a minute, blunt nail on the thumb. The feet and legs rather long in proportion to the size of the animal.

The fur is soft to the touch, fine and silky. The teeth, which are not robust, are yellow. A white streak runs from above and behind the eye to the nostrils, giving the nose a sharp and pointed appearance. This white line is marked on the upper surface with an edge of brown; a minute line of rufous runs from the nose through the eye, terminating at the ear, another, commencing under the eye, and running parallel with the last, terminates on the neck; a line of black, commencing on the forehead, extends over the back, and terminates at the tail; this is succeeded on each side by a broad line of whitish ash, then by a narrower line of brown commencing back of the neck, and running parallel with the rest, till it is narrowed to a point on the hips; this is succeeded by a line of pure white on each side, similar to the last, and, finally, by a broader and shorter stripe of brown; giving it on the back one stripe of black, two of light ash, and four of light brown. The head is cinerous; the ears have a white spot on their posterior surface, similar to the last species, and also to another described by Say, as the Sciunus quadrivitatus, with which I have compared it. The neck, and whole of the under surface, including the legs and thighs, are white. The tail, which is quite narrow, is dark brown above, edged with light rufous. Beneath, it is rufous near the roots, then a line of black, edged 
with light rufous; from the end of the vertebræ to the extremity, the hairs are black, a few of them are tipt with light rufous.

The number of species under the subgenera Spermophitus and Tamias, and the uniformity of character which they present, would, I conceive, warrant us in adopting them as true genera.

List of Quadrupeds procured by Mr. Tonnsend, and sent to the Academy of Natural Sciences.

1. Scalops Tonnsendii, (described above.)

2. Meles labradoria.

3. Mustela (putorius) ermina?

This specimen is in summer colors. The feet are white, possibly the commencement of a change to its winter pelage.

4. Canis.

5. Arvicola Tonnsendii, (described as above.)

6. Arvicola oreganii, (described as above.)

7. Neotoma Drummondii.

8. Mus leucopus?

Several very striking varieties, if not new species. 9. Meriones labradorius.

This quadruped is correctly described by Richardson. In the specimen originally noticed by Sabine, the tail was short, which has been given as one of its characters. The tail, however, is even longer than that of the GERBILLus canadensis, and it is believed that in the specimen of Sabine the tail had been mutilated, an accident very common to the whole family of rats.

VOL. VIII.-1839. 
74 NEW SPECIES OF AMERICAN QUADRUPEDS.

10. Spermophilus Douglassii-four specimens of various sizes.

11. Spermophitus Franklinii.

12. Spermophitus Richardsonii.

13. Spermophilus Tonnsendii, (described above.)

14. Spermophilus tridecem-lineatus.

15. Tamias quadrivittatus. (Say.)

16. Tamias Tonnsendii, (described above.)

17. Tamias minimus, (described above.)

18. Sciurus Douglassii, (Bennett,) (described above.)

19. Sciurus Richardsonii, (described above.)

20. Sciurus lanuginosus, (described above.)

21. Pteromys Sabineus-one specimen.

22. Geomys borealis. (Richardson.)

23. Geomys Tonnsendii-two specimens. (Richardson's manuscripts.)

24. Lepus Tonnsendii,-two specimens.

25. Lepus artemesia,-seven specimens.

26. Cervus leucurus. A fawn, resembling very strongly that of CERvus virginianus.

27. Pteromys oregonensis, -one specimen. 
Additional Remarls on the Genus Lepus, with corrections of a former paper, and descriptions of other species of Quadrupeds found in North America. By John Bachman.

IN a note contained in the last volume of the Transactions of the Academy of Natural Sciences, (page 403,) I stated that "I was induced to think that I had been led into an error in the synonyms of two of the species of Lepus. I had followed too confidingly the works of Desmarest, Cuvier, and those of American naturalists who copied their errors, in referring our common gray rabbit to LEPUS americanus, and had no opportunity of consulting the work of Erxlebein, the original describer of that species, before the article was in print. I, however, felt pretty confident, from the original account given of the northern hare in the $62 \mathrm{~d}$ volume of the London Philosophical Transactions, that it would prove to be the LePus americanus of Erxlebein, and identical with the species which was afterwards published as LEPUs virginianus, and I consequently inserted a note to that effect. Having since enjoyed ample opportunities of satisfying myself that my conjectures were right, I find it necessary to correct some of the synonyms in that article, and at the same time to add such information on the different species of this genus as I have since been able to collect. 


\section{Lepus glacialis, (Leach,) Polar Hare.}

LEPus glacialis, Leach, Ross' Voyage. I. glacialis, Supplement to Captain Sabine. L. glacialis, Parry's First Voyage, p. 188. L. glacialis, Franklin's Journal, p. 662. L. glacialis, Parry's Second Voyage, p. 321; Harlan's Fauna, p. 194. L. glacialis, Journ. Acad. Nat. Sci., Vol. VII., p. 2S5. Plate, in summer colors, 21.

\section{LEPUs americanus, (Erxlebein.) Northern Hare.}

Lepus americanus, Erxlebein's Systema Regni Animalis, p. 330: A. D. 1777. American Hare, London Philosophical Transactions, Vol. LXII.,pp. 11 and 376. Lepus hudsoni$u s$, Pallas glires, pp. 1 and 30 . LEPUs virginianus, Harlan's Fauna, p. 196: A. D., 1825. Lepus virginianus, Naturalist's Miscellany, Doughty's figure in autumn pelage, Vol. I., p. 217, plate 19. Audubon's Birds of America, Vol. II., plate 181, winter dress: in the talons of FALco chrysaetos.

Since my last article on the hares was published, I have had an opportunity of consulting the work of Erxlebein, which has satisfied me with regard to his description of this species. He describes it very correctly as "magnitudine medius, inter L. cuniculum, et timidum alpinum." Our gray rabbit, instead of being intermediate between the L. cuniculus, the common domesticated rabbit of Europe, and the Alpine hare, is smaller than either. "Pedes postici longiores quam in L. timido et cuniculo." These long hind feet are distinctive marks of the northern hare, but those of our gray rabbit are much shorter than those of the L. timido, or common hare of Europe. "Hieme in frigidioribus 
albus." Our gray rabbit, contrary to the assertion of most authors, does not become white in winter, in any latitude. "Habitat in America boreali, et fretum Hudsonium copiossimus." Dr. Richardson, and every northern traveller with whom I have conversed, have assured me that our gray rabbit does not exist at Hudson's Bay, where the northern and polar hares are the only species to be found. The original specimens sent from IIudson's Bay, from which Foster drew up his description in the $62 d$ volume (p. 276) of the London Philosophical Transactions, became eaten up by insects, but have been regularly replaced in the British Museum by others, which I have examined, as well as the original specimens described by Richardson; they are our northern hare, in winter colors, and are all marked LEPUs americanus. In fact, our little gray rabbit is very little known in England or Scotland, since, after an examination of all their principal museums, I met with but two specimens, much mutilated, one of which was not named; the other was very properly marked Lepus americanus, Harlan non Erxlebein. The rule of priority to which all naturalists are strictly bound to adhere, must, therefore, preserve for the northern hare the name of LEPUs americanus, whilst that of L.virginianus must stand as a synonym.

In page 308 of the Journal of the Academy, Vol. VII., I stated on the authority of Lewis \& Clarke, and Drummond and Richardson, that this species existed on the shores of the Pacific. I have since ascertained that they mistook the species for a very different one, which I designated in p. 349, under 
the name of LEPus campestris. The habit spoken of by Dr. Richardson, of its frequenting open plains and not thick woods, must therefore be referred, not to our northern hare, (L. americanus et L. virginianus, Harlan,) whose habits are very different, but to the prairie hare, (L. campestris.) The northern hare has not been found on either side of the Rocky Mountains, but appears to be restricted to the northern parts of the United States, the Canadas, Hudson's Bay, and the countries on the north-eastern coast of America, to the south of lat. 64,30 .

\section{Lepus sylvaticus, (nob.) Gray Rabbit. Ame- rican Hare.}

Lepos sylvaticus, Journal Acad. Nat. Sci., Vol. VII., part 2, p. 403: A. D. 1837. Lepos americanus, Cuv. Regne Animal. Lepos americanus, Desmarest's Mamalogie, p. 351. LEPUs americanus, Harlan's Fauna, p. 93. LEPUS americanus, Godman, Vol. II., p. 157. Audubon's Birds of America, Vol. II., plate 51, in the talons of FALCo borealis.

The range of this species must now be considerably restricted from that which has been assigned to it by authors. It does not appear to exist farther north than the New England states, and has not been found to the west of the Rocky Mountains, where it is replaced by other species.

\section{Lepus aquaticus, (nob.) Swamp Hare.}

Lepus aquaticus, Journal Acad. Nat. Sci., Philadelphia: p. 319, plate 22, No. 2. Read March 21st, 1837.

From specimens received from Alabama since 
my account of this species was published-one of which is deposited in the collections of the Academy of Natural Sciences of Philadelphia,-I have ascertained that the adult of this species is considerably larger than I represented it, being intermediate in size between the northern and polar hares.

\section{LEPUs palustris, (nob.) Marsh Hare.}

LEpus palustris. Read before the Acad. Nat. Sci. of Philadelphia, May 10th, 1836. Transactions Society, Vol. VII., pp. 194 and 336. Lepus Douglassi, (Gray.) Read before the Zoological Society of London, November, 1837. LEPus palustris, figured in Audubon's fourth volume of plates of the Birds of America.

To this species I have no farther information to add, than that it has since been found to exist plentifully in Texas, where it was found by Audubon, and where the specimen described by Mr. Gray, of the British Museum, was also procured by Douglass.

\section{LEPus Nuttallii, (nob.) Nuttall's Little Hare.}

Lepus Nuttallii, Journal Acad. Nat. Sci., p. 345, pl. 22.

To the infornation already given on this species, (Vol. VII., Journ. Acad. Nat. Science, from p. 45 to 48 ,) I subjoin a note which was kindly furnished me by Mr. Townsend. "The specimen from which you described, was doubtless that of an adult animal. We saw, perhaps, twenty or thirty, and all the same size; several of the hunters and 
trappers, attached to our party, who had perambulated the country for years, and were acquainted with, perhaps, every animal in it, said that it never attained a greater size. It is remarkably gentle, hopping before you like a domesticated animal."

\section{Lepus campestris, (nob.) Prairie Hare.}

Lepus campestris, Journal Acad. Nat. Sciences, Vol. VII., part 2, p. 349: A. D. 1837.

In my former article I offered reasons for believing this animal distinct from the northern hare, (L. americanus, Erx., and I. virginianus, Harlan,) to which my friend, Dr. Richardson, had referred it. I felt confident of this from the accuracy with which he was in the habit of describing his specimens. I have recently had an opportunity of ascertaining that I was correct in separating this species from our northern hare. Dr. Richardson, who holds an honorable station at Portsmouth, in the service of the government, had the kindness to visit me at London, and brought with him, among other rare specimens, that which, in his work, (Fauna Boreali Americana, p. 224,) he referred to the northern hare, (L. virginianus, Har., and $\mathrm{L}$. americanus, Erx.) We were fortunate in having before us specimens of the polar, northern, and prairie hare, and were not at a moment's loss in determining that they were three distinct species. The error into which he had inadvertently fallen, may be easily accounted for. He was unacquainted with our gray rabbit of the United States, or else he would have saved naturalists the trouble of 
correcting their synonyms. He had found the true LEPUs americanus of its first describer, in the northern hare, to which, by all our authors, our gray rabbit was referred, and he now sought for LEPUs virginianus of American writers, not suspecting that he had already found and described it under its true name of L. americanus.

The present species appears to be intermediate in size between the polar and northern hares, and although very distinct from either, approaches the former nearer than the latter. Its fur is soft and dense like that of the polar hare, but the hairs are not white throughout their whole extent, as in that species, having a narrow bar of brown in the middle, whilst all the remaining portions are white. The ears are shorter than those of the polar hare, but longer than those of the northern hare. From the northern hare (L. americanus, Erx.) it differs in its ears, which being an inch longer are marked by a decided black tip at their extremities, of an inch in breadth. The fur covering the ears is also shorter and more compact. There is a broad stripe of buff-yellow on the upper portion of the external surface of the ear, the hairs being sooty-brown at their roots; these markings are not found in the northern hare; the fur of the present species is whiter, and more compact than that of the northern hare, appearing, externally, snowy-white, without any admixture of fawn color, which is always visible through the loose covering of the other species. The fur of the northern hare is deep gray at the base, then broadly marked with yellowVOL. VIII.--1839. 
ish brown, and tipt with white; that of the present species is white at base and on the apical portion, and is only tinged in the middle with a narrow line of light brown. The summer color of the northern hare is reddish-brown above; that of the prairie hare, according to Lewis and Clarke, is lead color. The whiskers, in the specimens we compared, were in the latter species nearly all white, whilst those in the northern hare were nearly all black.

The fur on these three species, which interested us very much whilst engaged in comparing specimens, seemed perfectly adapted to the latitudes in which they are severally found to exist. That of the polar hare, which is found farthest north, was long, soft, and very dense, serving as a complete protection from the cold of the polar regions. That of the prairie hare, existing somewhat farther to the south, but still in a high northern latitude, was very compact, but shorter; whilst that of the northern hare, which is found as far south as the mountains of Pennsylvania, was much looser and thinner, indicating that the animal required less protection against the cold than either of the other species.

Mr. Townsend, in a private letter, remarks :- "I have frequently shot a hare on the Columbia river, both in summer and winter colors, but supposing it to be the old americanus, (northern hare,) I did not preserve a specimen." I have very little doubt but this will prove to be the species referred to in this article. It would be well, however, to compare specimens of the white hare found on the western side of the Rocky Mountains, with those on the Columbia river. 
To the industry and persevering zeal of Mr. Townsend, and to the kind attention and liberality of the members of the Zoological Society of London, I am indebted for the privilege of adding to our North American Fauna the following additional species of hares.

8. Lepus longicaudatus, (Gray.) Long-Tailed Hare.

LEPUS longicuudatus, (Gray.) Loudon's Magazine, Vol. I., New Series, p. 586, Nov. 1837.

Long-tailed hare, nearly the size of the northern hare; more slender in form, tail much longer; color blackish-brown above, white beneath.

The whole of the upper surface of this species is a mixture of black and pale brown, extending along the exterior of the thighs and legs, but becoming grayer on the cheeks; around the eyes grayish-white; upper surface of the tail blackish-brown; sides and under surface white; space behind the ears, on the back to the shoulder, reddish-brown. Under part of the neck and breast nearly similar to that of the back, but grayer, and having less black. Hairs, for half their length from the roots, silver-gray, blending into a pale yellowish-brown, then black, then pale yellowish-brown, and tipt with deep blackish-brown. The whole of the abdomen, interior of legs, thighs, under surface of tail, snowwhite; chin and throat grayish-white; soles pale rufous-brown; hind part of the outer surface of the ears, for two-thirds of their breadth, rufous-brown, thinly scattered with hair, black at the tips, edged with white at the sides; anterior third the color of 
the head, but a little grayer. Interior of the ears very thinly clothed with hair, nearly naked, of a soiled white color, becoming grizzled-brown on the outer edge-inner edge dingy yellow; whiskers black, some of the hairs whitish; claws dark brown.

\section{Dimensions.}

Length from point of nose to root of tail, - - $\quad$ - 19 inches 0 lines.

From nose to ear, about

From heel to longest claw, Waist to elbow,

Fore paws, Tail, (vertebræ,

" to end of fur,

Length of ears posteriorly, Across the eyes,

$\begin{array}{llll}4 & \text { " } & 4 \frac{1}{2} & \text { " } \\ 4 & \text { " } & 6 & \text { " } \\ 4 & \text { " } & 2 & \text { " } \\ 2 & \text { " } & 0 & \text { " } \\ 4 & \text { " } & 1 \frac{1}{2} & \text { " } \\ 5 & \text { " } & 3 & \text { " } \\ 5 & \text { " } & 3 & \text { " } \\ 1 & \text { " } & 6 & \text { " }\end{array}$

The specimen from which I have made the above description, is the original one from which Mr. Gray established the characters of this species. It was obtained by Douglass on his last visit to the south western coast of North America, and was sent to England after his melancholy death. The precise locality is not known, but is supposed to be on the north western part of Texas.

9. Lepus nigricaudatus, (Bennet,) Red-footed Hare.

Lerus nigricaudatus, (Bennet.) Proceedings of the Zoological Society of London, 1833, p. 41. Marked in the Catalogue of the Zoological Society, 582.

Color.-The whole of the upper surface fawn co- 


\section{REMARKS ON THE GENUS LEPUS.}

lor, tipt with black. Hairs on the back silverygray for one-third of their length, then pale fawn, then black, then fawn and tipt with black. Back of the neck brownish-black, slightly tipped with

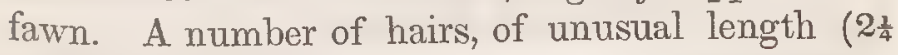

- inches) and delicacy, interspersed along the sides; in greatest abundance along the shoulders; these hairs are black from the base for two-thirds of their length, the remainder pale fawn. Sides, and under parts of the neck, dingy pale fawn, gradually becoming white on the chest. Haunches, legs, and under surface, white; the white hairs on the rump annulated with black, and near the root of the tail, almost entirely black. The hairs on the under surface of the feet red. Ears, posteriorly, for twothirds, black at the roots, gradually blending into fawn, and on the interior third mixed with black hairs, edged at the tip with black, the remainder of the edge fawn; the outer margin of the posterior surface to its apex, pure white. Inner surface of the ears nearly naked, except at the outer edge, where they are clothed with short, grizzled-brown hairs. Whiskers white and black, the former predominating. Chin and throat white. The marginal line of demarkation, between the color of the back and that of the under surface, is somewhat abrupt across the upper portion of the thighs, and very distinctly marked, so as to give the animal the appearance of a commencement of a change of color from fawn to white.

This is another of the discoveries of Mr. Douglass, and the specimen is believed to have been ob- 
tained on the mountains between the unsettled line of Texas and Mexico.

\section{Dimensions.}

Length from point of nose to root of tail, 'Tail, (vertebræ, )

Tail, including fur,

From heel to longest nail,

Head over the curve, about

From eye to nose,

Across the eyes,

Ears, posteriorly,

Greatest breadth,

\begin{tabular}{|c|c|c|c|}
\hline & ache & 301 & \\
\hline 1 & " & 6 & \\
\hline 2 & " & 6 & 66 \\
\hline 4 & $"$ & 7 & \\
\hline 4 & " & 6 & \\
\hline 1 & " & 9 & \\
\hline 1 & $"$ & 4 & \\
\hline 4 & “ & 7 & \\
\hline & " & 3 & \\
\hline
\end{tabular}

\section{Lepus californicus, (Gray,) Californian Hare.}

LEPus californicus, Gray, in Loudon's Magazine of Natural History, Vol. I., New Series, p. 586, Nov. 1837.

The Californian hare, nearly the size of the polar hare; in form and proportions resembling the English hare, (LEPUs timidus.) Upper surface dark brown; white beneath, tinged with yellow.

Color.-The top of the head and upper surface of the back mottled with black and pale yellowishbrown. The hairs on the back are annulated, as follows: pale plumbeous for two-thirds of their length, then very pale brown, then black, then yellowish-brown, and tipt with black; cheeks, breast, sides of the body, thighs, exterior of fore and hind legs, fawn, very slightly tipt, more or less, with black. Upper surface of the tail, and for a few 
vertebræ of the back, black; under surface yellowish-brown; around the eye white; whiskers shorter than the head, brown, with one or two white ones. An indistinct line, of the color of the head, running from the crown of the head over the neck to the shoulders, uniting the color of the head with that of the body; roots of the ears running to a point triangularly downward, dingy yellowish-white, growing lighter as it ascends the exterior portion of the hind part of the ear, until it loses itself about half way in the black color which terminates the upper half of the outside of the ear; the other half of the ear a grizzled reddish-brown, becoming darker as it ascends; the hairs being annulated, are a mixture of reddish-brown, black, and pale yellow; the interior edge of the ear is pale yellow, each hair tipt with black. The inner surface of one-half of the ear, interiorly, nearly naked, the outer thinly clothed with hair, gradually thickening to the outer edge, where it becomes grizzled-brown. Exterior edge of the ear, for two-thirds, white, the remainder a beautiful, soft, velvety-black. Soles of the feet dingy brown. The whole of the under surface, from between the fore legs to near the root of the tail, white, more or less tinged with yellow; this color extends to the interior of the legs and thighs.

\section{Dimensions.}

Length from point of nose to root of tail,

Head over the forehead, about From eye to point of nose,

22 inches 0 lines.

$\begin{array}{llll}5 & 6 & 6 & \text { "6 } \\ 2 & \text { "6 } & 1 \frac{1}{2} & \text { "6 }\end{array}$


Height of ear, posteriorly, 5 inches 10 lines. From heel to point of middle claw, 4 " 8 " Tail, including hair, about $\quad 3$ " 3 "

The above description is taken from the original specimen, deposited in the museum of the Zoological Society of London. It was obtained by Douglass, in California, and was sent to England after his death. It bears a strong resemblance to the one mentioned by Mr. Poinsett, as existing in Mexico, to which I referred at the close of my last paper on the hares.

\section{Lepus Richardsonii. Richardson's Hare.}

In the valuable, and daily increasing collection of the Zoological Society of London, I discovered two specimens of an undescribed species of hare, which the Society kindly permitted me to describe. It was sent over in the last collection of Douglass, which was made at California. I have named it after a naturalist, who, in addition to what he has already done for natural history, is still untiringly engaged in elucidating the unexplored treasures of the American continent.

This species is a little larger in size than the common American gray rabbit, (L. sylvaticus.) Its legs and ears, however, are much longer and thinner, and its tail shorter. Whole upper surface of a light mottled-gray color; beneath white.

Color.-Head, cheeks, and whole upper surface have a mixture of yellowish-white, black, and very pale buff color, giving it a mottled-gray appearance. 
Behind the ears, instead of the buff color found in most of the species, it is of a soiled, brownish-gray, extending around the neck and to the breast, continuing down the point and sides of the fore legs; the same color is found on the exterior of the thighs, and extending along the posterior portion of the hind leg. Under surface of the feet pale dark brown. Tail black above, pale brownish-yellow beneath. The hinder parts of the ear thinly covered with hair, white for two thirds of its breadth, with black for one and a half inches from its tip; the remaining third, for its whole length, grizzled black and pale yellow, edged with white to within an inch of the tip of the ear. Interior of the ear very thinly scattered with white hairs, gradually becoming black near the exterior edge. Chin and throat white, pale plumbeous at the roots. The whole of the under surface, from between the fore legs throughout the abdomen, white, tinged with pale yellow towards the sides. Whiskers black for half their length; the remainder white.

The above specimen was marked in the collection $\mathrm{A}, 586$.

Another specimen, in the same collection, (marked $\mathrm{A}, \mathrm{a}, 586$,) bears a general resemblance to the above, and appears to be in winter fur, whilst the former is in its summer dress. The dimensions in both specimens were precisely the same.

In this specimen the whole upper surface is a mixture of black and pale brown, the former color predominating. On the back of the neck dingy pale brown, blending on the throat and breast into

VOL. VIII. -1839 . 
yellowish-brown. The fore legs are of the same color, with a little black interspersed. The color on the back extends down the exterior part of the thighs, where it becomes a little browner. Soles of the feet the same as in the other specimen. Chin and throat dingy white. The whole under surface dingy white. Ears differing from the other specimen, in being yellowish-white in those places where they are white in the other, and browner where the grizzled color exists. Whiskers, in nearly all the hairs, black to the tips, with one or two white hairs intermixed.

\section{Dimensions.}

Length from nose to root of tail, 18 inches 0 lines.

" of head,

Tail, including fur, about

Length of ears, posteriorly,

Heel to end of middle claw,

Breadth of skull over the eyes,

Eye to point of nose,

Breadth of ear,

Length of elbow to wrist,

From toe to wrist,

$\begin{array}{llll}4 & \text { " } & 6 & \text { "6 } \\ 1 & \text { "6 } & 3 & \text { " } \\ 5 & \text { " } & 9 & \text { " } \\ 4 & \text { "6 } & 7 \frac{1}{2} & \text { " } \\ 1 & \text { "6 } & 6 & \text { " } \\ 2 & \text { " } & 1 \frac{1}{2} & \text { " } \\ 2 & \text { "6 } & 5 & \text { "6 } \\ 4 & \text { "6 } & 1 \frac{1}{2} & \text { "6 } \\ 2 & \text { " } & 3 & \text { " }\end{array}$

Nothing is known of the habits of these species, as the specimens sent by Douglass was not accompanied by any notes.

12. LePus Tonnsendii. Townsend's Hare. Pl. II.

This species, which is another of the discoveries of Mr. Townsend, and of which no specimen exists 
in any museum that I have had an opportunity of examining, is one of the most singular hares that has ever fallen under my notice. If the form is indicative of character, this animal, from its slender body, long hind legs, and great length of tarsus, must be one of the swiftest among the hares. Should the species referred to by Lewis and Clarke, which could clear twenty-one feet at a bound, be the LEPUs campestris of a former article, it will, to all appearances, find no contemptible opponent in a trial of speed with its next door neighbor, the present species.

Characters. - Size of the northern hare, (L. americanus.) Ears, tail, legs, and tarsus, very long. Color above light gray; beneath white.

Color.-Crown of the head, cheeks, neck, and whole upper parts, the front of the ears and legs, externally, gray, with a feint cream-colored wash. Hairs whitish, or silver-gray at base; then brownish white, then black, with a faint cream tinge, and ultimately tipt with black, interspersed with long silky hairs, some of which being wholly black. Chin, throat, whole under surface, interior of legs, the whole of the tail, (with the exception of a narrow dark line on the top,) pure white to the roots. Irides light hazel, around the eyes white. The tips of the back parts of the ears black; the external two-thirds of the hinder part of the ears white, running down the back part of the neck, and there mingling with the color of the upper surface; the interior third of the outer portion of the ear the same gray color as the back, fringed on the edge 
with long hairs, which are reddish-fawn at the roots and white at the tips. The interior of the ear is very thinly scattered with beautiful fine white hairs, being more thickly clothed towards the edge where it is grizzled-black and yellowish, but the edge itself is fringed with pure white, becoming yellowish towards the tip, and at the tip is black. Whiskers nearly as long as the head, for the most part white, black at the roots, a few hairs are pure white, others wholly black.

The specimen from which the above description and drawing were taken, was a female, procured by Mr. Townsend on the Walla-walla, one of the sources of the Columbia river. The following note, by the discoverer of this hare, reached me at Edinburgh, after the above description was made. It will afford valuable information in regard to its habits.

"The specimen is that of a female-and the species is common on the Rocky Mountains. I made particular inquiries, both of the Indians and British traders, as to the changes it undergoes at different seasons, and they all agreed that it never was lighter colored. We first saw it on the plains of the Black-foot River, west of the mountains, and observed it in all similar situations during our route to the Columbia. When first seen, which was in July, it was lean and unsavory, having, like our common species, the larva of an insect imbedded in its neck; but when we arrived at Wallawalla, in September, we found the Indians, and the persons attached to the fort, using them as a com- 
mon article of food. Immediately after we arrived, we were regaled with a dish of hares, and I thought I had never eaten any thing more delicious. They are found here in great numbers on the plains covered with wormwood, (Artemesia.) It is so exceedingly fleet that no ordinary dog can catch it. I have frequently surprised it in its form, and shot it as it leapt away, but I found it necessary to be very expeditious, and to pull trigger at a particular instant, or the game was off among the wormwood, and I never saw it again. The Indians kill them with arrows, by approaching them stealthily, as they lie concealed under the bushes, and in winter take them with nets. To do this, some one or two hundred Indians, men, women, and children, collect, and enclose a large space with a slight net, about five feet wide, made of hemp; the net is kept in a vertical position by pointed sticks attached to it, and driven into the ground. These sticks are placed about five or six feet apart, and at each one an Indian is stationed, with a short club in his hand. After these arrangements are completed, a large number of Indians enter the circle, and beat the bushes in every direction. The frightened hares dart off towards the net, and, in attempting to pass, are knocked on the head and secured. Mr. Pambrun, the superintendent of Fort Walla-walla, from whom I obtained this account, says that he has often participated in this sport with the Indians, and has known several hundred to be thus taken in a day. When captured alive, it does not scream like the common gray rabbit, (LEPUs sylvaticus.) 
This hare inhabits the plains exclusively, and seems particularly fond of the vicinity of the aromatic wormwood.* Immediately as you leave these bushes, in journeying towards the sea, you lose sight. of this hare. The specimen I have sent is not the largest I have seen, some individuals measuring several inches more in length."

\section{Dimensions.}

From nose to insertion of tail, 21 inches 0 lines. Tail to end of hair, " (vertebræ,) about,

Ears, measured posteriorly, $\begin{array}{llll}5 & 6 & 6\end{array}$ 3 " 3 " Length of head, (measured over the forehead,)

From eye to nose, Heel to longest nail,

\section{Lepus artemesia. Wormwood Hare.}

Characters.-Small; of a gray color, with pale rusty color on the back of the neck and legs. Tail, above, the color of the body; beneath, white. Under parts of the neck, and lower surface of the body, white-all the fur being gray at the base. Ears as long as the head; tarsus well clothed.

Description.-The head is much arched; upper incisors deeply grooved. The color of this species is grizzled-black, and brownish-wliite above. The fur is soft, pale gray at the base, shaded into

* The specimen was stuffed with this article. 
brownish externally, annulated with brownish-white near the apex, and black at the tips. Under parts, and inner sides of limbs, white, the hairs pale gray at the base. Neck, with the hairs on the sides and under parts, gray, tipt with brownish-white, having a faint yellow hue. Chin and throat grayish-white, the hairs being gray at their base and white at their tips. The whole back of the neck and limbs, exteriorly, of a pale rusty-fawn color; those on the neck uniform to the base. Feet, beneath, a very pale, soiled, yellow-brown. Tail colored above as the back, with an admixture of grayish-black hairs; beneath white. Ears, externally, on the anterior part, colored as the crown of the head, posteriorly ashy-white; at the apex margined with black : internally, nearly naked, excepting on the posterior part, where they are grizzled with grayish-black and white; in the apical portion they are chiefly white.

\section{Dimensions.}

Length from nose to root of tail, 12 inches 0 lines. From heel to point of longest nail, 3 " 2 " Height of ears, externally, From ear to point of nose,

$\begin{array}{llll}2 & \text { " } & 8 & \text { " } \\ 2 & \text { " } & 7 & \text { " } \\ 1 & \text { " } & 1 & \text { " } \\ 1 & \text { " } & 9 & \text { " }\end{array}$
Tail, (vertebræ,) about " to end of fur,

Mr. Townsend, who procured this species, remarks: "This small hare inhabits the wormwood plains near the banks of the streams in the neighborhood of Fort Walla-walla. I cannot define its range with any degree of certainty, but I have reason to 
believe that it is very contracted, never having met with it many miles from this locality. It is here abundant, but very shy and retired, keeping constantly in the densest wolmwood bushes, and leaping with singular speed from one to another when pursued. I have never seen it dart away and run to a great distance like other hares. I found it very difficult to shoot this animal, for the reasons stated. I had been residing at Fort Walla-walla for two weeks, and had procured only two, when, at the suggestion of Mr. Pambrun, I collected a party of a dozen Indians, armed with bows and arrows, and sallied forth. We hunted through the wormwood within about a mile of the fort, and in a few hours returned, bringing eleven hares. The keen eyes of the Indians discovered the little creatures squatting under the bushes, where, to a white man, they would have been totally invisible. This hare, when wounded and taken, screams like our common species.

\section{Lepus Bachmani, (Waterhouse.) Bachman's Hare.}

Lepus Bachmani. Manuscript of G. R. Waterhouse. Manuscript edition to Zoological Society, Catalogue A, 587. Read before the Zoological Society of London, August $14 \mathrm{th}, 1838$.

In examining the collection of American Mammalia, in the museum of the Zoological Society of London, aided by my friend, Mr. Waterhouse, the curator of the Museum, to whom I am indebted for . many facilities in examining specimens, and for 
many acts of personal kindness,-we discovered a small species of undescribed hare, sent from the western coast of America, by Douglass. He described it under the above name before the Zoological Society, and has politely offered me the use of his manuscript, from which, in order to render the synopsis of our American species of this genus as complete as possible, I have copied his description.

"General Characters. - In form, this species bears a general resemblance to LEPUs palustris, but is only one-third of its size. Color less yellow; ears longer in proportion; feet densely clothed with hair, so as to cover the nails. Lower surface of the tail white; upper surface gray-black-noșt of the hairs being annulated near the tip with whitish. Upper incisors much arched and deeply grooved.

"Fur very long and soft, of a deep gray color, annulated near the apex with brownish-white, black at the points; on the belly gray at the base; chest and fore part of the neck, with the hairs, colored as those of the sides of the body; viz., the visible portion is brownish-white, each hair being dusky at the tip. Chin and throat gray-white. The hairs on the head colored like those of the body. An indistinct, palish, longitudinal dash on the flanks, just above the haunches; roots of the tail, beneath, white. The general color of the tarsus, above, is white; the hairs, however, are grayish-white at the base, then annulated with very pale buff color, almost white, and pure white at the points. The sides of the tarsus brown. The long hairs which cover the under part of the tarsus, as well as that VOL. VIII. -1839 . 
of the fore feet, deep brown. The fore feet, above, very pale brown, approaching to white. The hairs covering the toes, principally white. Claws slender and pointed, that of the longest toe remarkably slender. Ears longer than the head, sparingly furnished with hair, the hairs minute and closely adpressed, exterually, on the fore part grizzled with black and yellowish-white, on the hinder part grayish-white; internally, the ears are white, towards the posterior margin obscurely grizzled with blackish, at the margin yellowish, and the apical portion is obscurely margined with black; at the base, the hairs are of a woolly nature, and of a very pale buff color; the hairs on the occipital part of the head, and extending slightly on the neck, are of the same color, and of the same woolly character."

This animal possibly may not be an adult, but neither in the teeth, as far as the stuffed spccimen will allow of the examination, nor in the character of the fur, can I see any reason for believing it to be young, excepting that it is much under the ordinary size of the species of the genus Lepus; and a]though it may possibly not be an adult, it certainly is not a very young animal. Compared with Lepus palustris, with which species it was sent over by Mr. Douglass, it presents the following points of distinction:-Althougln the animal is not above one-third of the size of LLPus palustris, its ears measure about one-fourth of an inch more in length. In fact, in the present animal, they are longer than the head, whereas, in Lepus palustris, they are much shorter. The next most important difference 
is in the feet, which, instead of having comparatively short and adpressed hairs, which, consequently, do not conceal the claws; they are, in this species, long and woolly, especially on the under parts, concealing the claws, and extending upwards of a quarter of an inch beyond their tips. The claws are more slender and pointed, especially the fore feet. Beside these essential differences, there are some others which, perhaps, may be considered of minor importance. The fur is much softer and more dense; the longer hairs are extremely delicate, while in L. palustris they are comparatively harsh. The LEPUs palustris is in color distinctly washed with yellow, whereas the pale annulations of the hair, which give the yellow hue to that species, are in the present animal almost white; there is, however, an obscure brownish cast, and towards the haunches, a very indistinct, yellowish tint.

This specimen was procured in the south-westerm portions of North America, supposed to be between California and Texas.

\section{Dimensions.}

Length from point of nose to root of tail, 10 inches 0 lines. Tail to end of fur, about Ear, internally, 1 " 3 " 2 " 8 " From heel to point of longest nail, 3 " " 0 " From nose to ear,

2 " $55^{\frac{1}{2}}$ "

General Remartis.

Although I have published these species without any regard to arrangement, and for the most part 
in the order in which they were found, yet they may be easily arranged under several very natural groups. The species existing in high northern latitudes, and becoming white in winter,-such as LEPUs glacialis, campestris, and americanus,-will form the first group, to which L. variabitis, existing in the north of Scotland, although a very distinct species, is closely allied. Next may be placed the species with long ears and tails, such as L. Tonnsendii, longicaudatus, nigricaudatus, Richardsonii, and californica, all of which are confined to the western coast of North America. Lepus aquaticus and palustris, with the tarsi thinly clothed with hair, the nails extending beyond the fur, adapting them to their aquatic habits, will form another group, to which, in size, color, and shortness of tarsus, $\mathrm{L}$. sylvaticus is allied, although it differs from the others in having its feet thickly clothed with fur. 'The L. artemesia, Bachmani, and Nuttallii, being comparatively diminutive in size, with short ears, head, and tail, will form the last, and very natural group.

The species which have been given in this article, have not been published hastily, and without mature reflection, or a rigid test of examination. I would also add, that they were all, with the exception of L. Nuttallii, which is sufficiently distinct, compared and examined at the Museum of the Zoological Society in London, by some of the most eminent naturalists of Europe, who unhesitatingly acknowledged them as true species, and marked them as such in their catalogues and on their specimens. Although the 
industry and zeal of our travellers and naturalists, Drummond, Douglass, and Townsend, (the two former having perished in their ardor to advance the cause of natural science,) have greatly added to our list of the species of this genus, yet much remains to be done, and a wide field is still open for farther discoveries. The far west seems to be a region where the genera Lepus; ARctonys, and SPermophilus, principally abound, and rich stores, in every department of Natural History, lie in wait, to reward the zeal and enterprise of future naturalists.

The following Species must be added to the List of Mr. Townsend's Quadrupeds.

PTERomys oregonensis. Oregon Flying Squirrel.

Characters.--Intermediate in size between P. volucella, and the northern PTERoMrys sabrinus. Ears longer than in the latter species; fur more compact; the lobe of the flying membrane joining the fore foot, much longer in proportion, making that membrane broader; foot larger; general color above brown, beneath yellowish-white.

Description.-All the fur of this species is deep gray at the base, that of the back tipt with yellowish-brown; tail pale brown above, dusky towards the extremity; beneath brownish-white. Whiskers numerous, and very long, chiefly of a black color, and grayish at the tips. Hairs covering the flying 
membrane chiefly black, most of them slightly tipt with pale brown; feet dusky; around the eyes blackish ; ears with minute, adpressed, brown hairs externally, and brownish-white internally.

This species differs from P. sabrinus in several very striking particulars; although a smaller animal, the arm of the wrist which supports the flying membrane, is $11 \frac{1}{2}$ lines in length, whilst that of the former is only 9 : thus the smallest animal has the largest flying membrane.

The fur of P. sabrinus is much the longest. The fur on the belly of the latter is white, whilst that of oregonensis has an ochreous tinge. The hairs on the tail of P. sabrinus is only slightly tinged with lead color at the roots, whilst in oregonensis it extends to half the length of the hairs. The greater length, and less breadth, however, of the ear of the latter, is a sufficient mark of distinction.

From our little Pteronys volucella, the difference is so great that it is unnecessary to institute a particular comparison. Besides being much larger than our little species, and not possessing the beautiful downy white on the belly, the two species may be instantly detected, in the volucella having its hairs white to the roots, which is not the case in the other species.

\section{Dimensions.}

Length from point of nose to root of tail,

Tail to point of fur,

Height of ear, posteriorly,

6 inches 8 lines.

6 " 0 "

0 " 7 " 
Breadth between the outer edges of the flying membrane, 8 inches 0 lines. Longest hind toe, including nail, 0 " $\quad 5^{\frac{1}{4}}$ " Longest fore toe, including nail, 0 " $5 \frac{1}{2}$ " $\begin{array}{lllll}\text { From heel to point of nail, } & 1 & 6 & 6 \frac{1}{2} & \text { " } \\ \text { Nose to ear, } & 1 & \text { " } & 6 & \end{array}$

Habits.-Mr. Townsend remarks, in regard to this species, that it inhabits the pine woods of the Columbia, near the sea; very rare. Habits of the P. volucella.

\section{GEonys borealis, (Richardson.)}

Pseudostoma borealis. Manuscript notes of Dr. Richardson.

Among the specimens brought by Mr. Townsend, were two differing considerably in size, which I find identical with one which had been procured on the Columbia river by Douglass, and which was in the possession of Dr. Richardson. As he is preparing a monograph of this perplexing genus, I should not have noticed the present and following species in this paper, were it not for the necessity I am under, of indicating the species of quadrupeds brought to the United States by Mr. Townsend. I have, therefore, adopted the names of Richardson, who will give more ample descriptions, and is fully entitled to the credit of having been the first to detect the species.

General color pale gray, the upper parts more or less washed with yellow. Insides of pouches, the 
whole of the under parts, the feet and tail, white. Hair of the upper and under parts of the body, dark slategray at base. Ear distinct, not hidden by the fur, consisting of a small round opening, surrounded by an elevated ridge, the highest portion of which is behind, and about one line in height. Claws white, those of fore feet very long. Incisors yellow in front, those of the upper and lower jaw of the same color; with a lens, a faint groove is seen in the upper incisors, situated close to the inner margin. Tip of muzzle naked; feet bare beneath; behind the ears dusky.

\section{Dimensions.}

From nose to root of tail, Tail,

Tarsus and claws,

Central claw of fore foot, From nose to ear,

7 inches 6 lines.

2 " 0 "

1 " $1 \frac{x}{2}$ "

0 " 5 "

1 " $66^{7}$ "

Hind foot.-The central toe is the longest; outer toes equal and short. A long brush of stiff white hairs on the inner side of the two innermost toes of the fore feet; inner toe rather short; outer toe the next in length; middle toe longest; the one on each side about equal.

In the young specimen, the back had a deep yellow wash. Length of body 5 inches 6 lines; of tail 2 inches.

Mr. Townsend's specimens were procured on the Columbia river. 
Geomys Townsendii, (Richardson's Manuscripts.)

General color very pale gray above, with a faint yellowish wash; muzzle dusky gray, under parts grayish-white; chin pure white; tail and feet white, the former grayish above, hairs of the back very pale gray at the base, pale yellow at the apex; the extreme tip cinereous. Teeth yellowish-white. Upper incisors with a faint groove near the internal margin. Claws and fore feet moderate white.

\section{Dimensions.}

From nose to tail,

7 inches 6 lines.

Tail,

Tarsus,

Central claw of fore foot,

2 " 9 "

1 “ $3 \frac{1}{2}$ “

Nose to ear,

0 " 5 “

1 " 5 "

The specimen was procured by Mr. Townsend oll the Columbia river.

I am obliged to confess that I should not have ventured to publish this species as distinct from the preceding, on my own responsibility. The discriminating eye of Dr. Richardson, however, who has studied this genus more carefully than I have had an opportunity of doing, may have detected marks of difference which I have not been able to discover. As the species, however, will be given under the above name, I have found it necessary to indicate it here.

voL. virr.--1839. 
Catalogue of the Crustacea brought by Thomas Nuttall and J. K. Townsend, from the West Coast of North America and the Sandwich Islands, with Descriptions of such Species as are apparently new, among which are included several species of different localities, previously existing in the collection of the Academy. By J. W. RaNDaLL.

Read June 18th, 1839.

Crustacea Brachyura.

Fam. Maiada.

Genus Libinia, (Leach.)

Libinia-(variety of L. canaliculata? Say.) Mus. Acad.

The hitherto described species of the genus LIBINIA, as restricted by M. Milne Edwards, have so great a mutual resemblance, that we hesitate to consider the present one as new, until more specimens have been obtained for comparison.

Its principal peculiarities may be thus stated.

L. Testa multispinosa, manibus politis, vix granulatis.

Rostrum elongate, somewhat flattened above, and channeled at base. Anterior feet polished, and not perceptibly granulated. Shell pyriform, only slightly convex, and studded with a great number of sharp spines, interspersed with tubercles. The lateral spines are six or seven on each side, the dorsal row about eight, intermediate ones about a dozen on each side, more or less elongated. The tubercles are about as numerous as the spines, and scattered irregularly between them. Second pair 
of feet scarcely one and one-fourth times the length of the carapax.

Length of shell, in the present specimen, (rostrum inclusive,) scarcely $1_{\frac{1}{1}} \frac{4}{0}$ inches, but, probably attains a greater size.

A single specimen, brought by Mr. Nuttall from Upper California.

Compared with such specimens as I have seen of the $\mathrm{L}$. canaliculata, the shell here is less convex, the rostrum more flattened above, the anterior feet more smooth, and the spines and tubercles more numerous.

It may be named, provisionally, L. affinis, allied to L. emarginata, Leach, and to L. dubia, Edwards, which last is described as being less spinous than the L. canaticulata.

Genus Herbstra, (Edwards.)

H. parvifrons. Mus. Acad.

Corpore depresso, in latere spinoso, pedibus spinosis, levitèr dilatatis, manibus lævigatis, dactylis apice serrulatis.

Body flattened above, punctured, somewhat hairy; sides spinous, especially anteriorly; rostrum very short; feet spinous above; hands of the anterior pair with only a few very small spines at their base; pincers without teeth, except towards their apices, where, for at least one-third of their whole length, they are hollowed out on their prehensile side, and serrated laterally, so that, when closed, they become interlocked at their extremities by means of the serratures. 
One specimen, brought by Mr. Nuttall from western America.

Length of carapax, scarcely one inch.

\section{Genus Chorints, (Leach.)}

The following species of Chorinus is preserved in the Museum of the Academy without any indication of its name or locality; as it disagrees in its details with the only four species of the genus which I have seen noticed, viz., the C. aries, (Latr.) the C. heros, (Herbst.) and the C. aculeata, and C. Dumerilii, (Edwards,) I have ventured to describe it as new.

\section{Chorinus armatus. Mus. Acad.}

Pedum pare antico spinoso; manibus tuberculosis; spinis frontis divaricantibus, testa lanuginosa, utrinquè 4-spinosa, posticè 2-spinosa.

Body elongate pyriform; frontal spines extremely long, divergent; supra-orbitar spine very strong; post-orbitar spine dilated at base, and moderately produced. Shell depressed in the middle, but anteriorly convex, on each side moderately convex; an obtusely rounded elevation behind the middle; apex somewhat produced, crowned with a short spine, having another behind it; sides, each with four great spines, exclusive of the post-orbitar one. Feet downy; anterior pair about $2_{\frac{1}{2}}$ times the length of the carapax; arm spinous; hand and wrist studdèd with granules; posterior feet smooth, second pair nearly $1 \frac{1}{2}$ times the length of the third. 
Length of carapax behind the base of the frontal horns nearly $3 \frac{1}{2}$ inches.

Genus Epialtus, (Edwards.)

\section{E. Nuttallii. Mus. Acad. Pl. III.}

Testa polita, atropurpurea, maculis testaceis posticè sub. ocellatis ornata; margine obtusè tridentata; rostro depresso, apice profundè emarginato: corpore infrà sanguineo, oeellis testaceis ornato.

Shell smooth, dark purplish, besprinkled with testaceous spots becoming large and somewhat ocellate behind, and still larger and brighter on the under side of the body; rostrum broad at base, flattened above; apex profoundly notched; carapax moderately elevated, having three obtuse, distant teeth on either margin, including the post-orbitar one; hands in the male very large.

Length of carapax in the male about four inches, inclusive of the rostrum; greatest breadth, a little over three inches.

A single pair, brought by Mr. Nuttall from Upper California; the female, but an indifferent specimen, is represented on the accompanying plate,* because the great size of the male does not admit of its being figured without reduction. The male differs from the female, not only in being twice as large, but in its colors, which are brighter, and in its spots, which are larger.

* On the plate the name Libinia Nuttallii has been appended, a mistake which could not be corrected after the impression had been struck off. 


\section{E. productus. Mus. Acad.}

Testa elongata, subquadrata, indistinctè maculata; margine utrinquè pone oculos tridentata; rostro profunde bifido, utrinquè unidentato.

Carapax elongate, subquadrate, fuscous, with some obscure spots; rostrum dilated at base, flattened above and divided by a broad notch; on each side, the base is produced into a great tooth, directed anteriorly; marginal teeth of the carapax, three on each side, including the small post-orbitar one. The middle tooth is so great that its base occupies nearly the whole anterior side of the carapax, and is so straight on its outer edge that it forms almost a right angle with the anterior margin; posterior tooth stout, growing from the middle of the margin

Length of carapax, inclusive of the rostrum, about $1 \frac{3}{4}$ inches.

A single female, brought by Mr. Nuttall from Upper California. The specimen not being alive when discovered, had, perhaps, undergone some alteration in color.

This species has a great resemblance to the EPIALTus marginatus, (young, figured by Mr. Bell in the Transactions of the Zoological Society of London, but may be particularly distinguished by the position of the anterior lateral tooth of the carapax, which, in that species, is not placed immediately behind the eye, but in the middle of the curve of the anterior margin; moreover the anterior angles are not so much expanded as in the present species. 
Fam. Parthenopiadce.

Genus Parthenope, (Fabr.)

P. horrida, (Linn.) Mus. Acad.

Brought from the Sandwich Islands by J. K. Townsend.

Fam. Cancrida.

Genus Platypodia, (Bell.) (CAncer, Latr. and Edwards.)

P. granulosa, (CANCER granulosus, Ruppell,) different from the P. granulatus, (C $\mathrm{CANCER}_{\mathrm{A}}$ granulatus, Audouin.)

Several specimens, brought from the Sandwich Islands, by Mr. Nuttall and J. K. Townsend. The four posterior pairs of feet are not quite smooth, but somewhat granulated in each specimen; in other respects it agrees with the description of the $\mathrm{C}_{A N}$ CER granu?osus.

\section{Genus Lagostona, (Edwards.)}

L. nodosa. Mus. Acad.

Testa transversa, subconvexa, nodosa, posticè sub-depressa, lateribus, 5-dentatis; fronte obtusa, vix 4-lobata; pedibus anticis, reticulatis, in maribus crassis, tarsis tuberculosis.

Shell more than one-half broader than long, but little convex, and somewhat depressed behind; anteriorly, and antero-laterally, divided by deep 
grooves into great tubercles, the posterior ones being flattened above; front very obtuse, sinuous, properly speaking, two-lobed, the lobes being a little produced toward the outer angle; median fissure tolerably well marked; orbits surrounded with tubercles, having about three above and two beneath ; margin with about five great obtuse teeth on each side, of which the posterior pair is smallest; most of these teeth are dilated on each side at base, forming small tubercles, very distinct when viewed from beneath; anterior feet very stout in the male; hand and wrist somewhat reticulate with irregular elevated lines; four posterior pairs of feet a little rough on their superior edge, the roughness increasing in the direction of the tarsi, which are studded with small tubercles; the third joint of the outer maxillary feet, has an anterior inner notch, less large than the anterior one.

A single male specimen, brought by Mr. Nuttall from the Sandwich Islands; its length is $1_{\frac{1}{1} \sigma}^{1}$ inch, breadth fully $1_{\frac{6}{1} \sigma}$ inches.

A small species, nearly allied to the present, and, perhaps, a young specimen of it, has been brought by Dr. Morton from the West Indies; no spines exist on the feet of either.

This species has a striking resemblance to the Cancer inequalis? of Olivier, as figured by Savigni in the great work on Egypt, but Olivier says that the hands of the anterior feet in his species are smooth. The C. inequalis is probably another species of the same genus. 


\section{Genus Xantho, (Leach.)}

The following species of $\mathrm{X}_{\mathrm{ANTHo}}$ seems to have a close analogy to several others already described, without well agreeing with any of them; indeed, the descriptions heretofore given by authors of several species of this genus, are too brief, when considered as applying to a group so extensive, so widely diffused, and composed of individuals nearly related to one another.

\section{X. intonsus. Mus. Acad.}

Testa polita, nodosa, levitèr convexa, margine utrinquè 4-dentata: fronte producta, inequaliter 4-lobata; pedibus compressis, valdè ciliatis; manibus suprà eristatis, externè carinatis.

Shell polished, not greatly convex, anteriorly and antero-laterally divided by broad, shallow, somewhat interrupted grooves, into several great, but little elevated lobes, thinly besprinkled with large, unequal punctures, very visible through a microscope; antero-lateral margin with four teeth on each side, the two anterior of which are merely rounded crests; in each depression between the teeth, a small fissure is visible, dividing their bases from one another; postero-lateral margin somewhat depressed; front four-lobed, the two middle lobes approximate, rounded at tip, and considerably produced, the outer ones small, but very distinct; anterior feet stout, with a few punctures scattered over the surface; hands with a great crest above, vOL. vIII. - 1839 . 
and three or four obtuse, but well defined longitudinal elevations on the outer side; intermediate spaces reticulated with small elevated lines, presenting to the eye a kind of cellular texture; anterior inner tooth of the carpus well defined; pincers canaliculate, brown, inclining to black; four posterior pairs of feet flattened on the sides, having the upper edge sharp, but gradually dilating in the direction of the tarsus, and covered above and underneath, throughout their whole length, with long, dense, light brown hair, which, on the upper side of the two last joints of most of the feet, as well as on the tarsi, is disposed in longitudinal rows.

A single female specimen brought by Mr. Nuttall from the Sandwich Islands. Its length is about $1 \frac{8}{10}$ inches; greatest breadth fully two inches.

It is probably very nearly related to the $\mathrm{X}$. incisus, (Edw.) but that species is described as having on the outer face of the hands, several ranges of tubercles, and many small transverse crests on the carapax over the hepatic and stomachal regions.

The X. Rumphii, (Guerin,) (X. octodentatus, Edw.) seems also to be nearly allied to it, but there the front is but little advanced, and divided into only two lobes; the anterior angles of the carapax seems also to form a curved line with the front, whereas, here they are produced almost to a level with its outer lobes.

The X. acasta, (CANCER acasta, Herbst.) is probably another very nearly allied species, but its carapax, according to M. Edwards, appears to be smooth. 
The present species may be referred to that section of the genus in which M. Edwards places those species which have a crest on the upper side of the hands, as well as on the four posterior pairs of feet.

\section{Genus Errsus, (Edwards.) \\ E. laevimanus. Mus. Acad.}

Testa transversa, polita, nodosa, margine obtusè 4 dentata; fronte producta, vix sinuata; manibus lævigatis, tarsis tuberculosis.

Carapax one-half broader than long, not very convex, anteriorly and antero-laterally divided by several grooves into large but little elevated tubercles; margin with four large obtuse teeth; front produced,-almost imperceptibly sinuous; hands smooth; pincers very large; posterior feet short, a little flattened, nearly smooth, except toward the last joint, which is somewhat rough, and the tarsi, which are studded with small tubercles. Color yellowish; length of carapax from $\frac{8}{10}$ of an inch to rather more than an inch.

Two male specimens, brought by Mr. Nuttall from the Sandwich Islands.

In form it is much like the Lagostoma, described above, but the position of the antennæ sufficiently distinguish it. Moreover, the tubercles of the carapax are greatly depressed, and the body is less broad, and less depressed behind, in which respect it disagrees also with the CANCER inequalis? (Savigni, Egypt.) 
Genus Cancer, (Leach, and Bell,) (Platycarcinus, Latr. and Edw.)

C. productus. Mus. Acad.

Testa depressa; fronte subquadrata, valdè producta, obtusè 5 -lobata, lateribus 9 vel 10 -lobatis.

Shell greatly flattened behind the front, and antero-laterally; front greatly produced beyond the orbits, terminating in five nearly equal and not very distinct lobes, the middle lobes not greatly produced beyond the lateral ones; antero-lateral margin of the carapax with nine or ten nearly equal, obtuse, lobe-like teeth, postero-lateral margin very concave; anterior feet tuberculous above; pincers very short.

One specimen, brought by Mr. Nuttall from West America.

Length hardly one inch, but probably attains a greater size.

\section{C. irroratus, (Say.) Mus. Acad.}

Two specimens, brought from West America by Mr. Nuttall; not essentially differing from those found on the coast of New England.

'This species is so liable to vary with age, both in the thoracic markings and in the shape and direction of the marginal teeth, that without care one might easily mistake varieties for distinct species.

M. Edwards states that the frontal teeth in this genus form an uneven number, one always growing 
from the middle, but here there are frequently only four equidistant frontal teeth.

Genus Trapezium, (Latr.)

T. cymodoce, (CANcER cymodoce, Herbst.) (Trapezium dentifrons, Latr.) Mus. Acad.

Several specimens, well agreeing with the figure of T. cymodoce, have been brought from the Sandwich Islands by Mr. Nuttall and J. K. Townsend.

Fam. Portunida.

Genus Lipa, (Leach.)

L. sanguinolenta, (Herbst.)

Many specimens, brought by Mr. Nuttall and J. K. Townsend from the Sandwich Islands.

\section{Genus Thalamita, (Latr.) \\ T. pulchra.}

Testa subhexagona, cœruleo-maculata, margine utrinquè 7-dentata, dentibus secundo et quarto minimis; fronte 8-dentata.

Carapax somewhat hexagonal, disk with several transverse, distinctly elevated lines, formed of very minute granules; post frontal, and antero-lateral portion granulated, some rugosities on each side behind the middle, remainder of the surface nearly smooth; front with eight large, elongated, nearly equal, obtusely rounded teeth, those on one side a little diverging from the corresponding ones on the other, and all of them somewhat flattened above; 
second tooth from the middle bifid beneath; margin with seven teeth on each side, of which the second and fourth are very small, the others large, sharp, and nearly equal; color bright vermillion, variegated with greenish-blue spots, some single, some in clusters, and varying much in shape and size, though very symmetrical, as regards the two sides of the carapax; anterior feet very stout and angular, the upper surface with many large granulations; hand about the length of the carapax, with five stout teeth on its upper side, and a basal tubercle; carpus with four tecth, that on the inner angle of great size; arm with four teeth, the terminal one greatly dilated at base and flattened; pincers profoundly canaliculate; four posterior pairs of feet somewhat flattened, and having their two last joints more or less profoundly channeled on each side, but the last pair with a double channel on the outer surface of its three last joints, the first of which has a strong spine noar the extremity; the natatory plate is armed at tip with a small corneous tooth.

Length of carapax from 2 to more than $2 \frac{1}{2}$ inches.

Two specimens, brought from the Sandwich Islands by Nuttall and Townsend.

It seems to be allied to the T. erythrodactyla, (Lam.) and probably to the CANCER seriatus, (Limn.)

Genus Podophtmalmus, (Lam.)

P. vigil, (Fabr.) Mus. Acad.

Brought in considerable numbers from the Sandwich Islands, by Nuttall and Townsend. 
Fam. Thelphusiadoe.

\section{Genus Potamia, (Latr.) (Boscia, Edwards.)}

Of two closely allied species of this genus, preserved without labels in the collection of the Academy, the only very distinct character that can be made use of for determining, which is the P. dentata of Latreille, is this, viz., that the orbits are entire; one of the present species agreeing with the description in this respect, and not essentially differing from it in other points, as far as can at present be determined, I have supposed, therefore, to be the P. dentata.

\section{P. dentata, (Latr.) Mus. Acad.}

Testa depressa, utrinquè obliquè impressa; fronte angustata, bilobata, truncata.

Front between five and six-twentieths of the width of the carapax in its greatest diameter, not bifid, but divided by a superficial groove into two truncate lobes; on each side of this groove is a small transverse indentation; orbits without a notch at the outer angle; a very profound and oblique groove, extending from the antero-lateral margin of the carapax toward the median impression, in a direction to form with it an obtuse angle, but interrupted a little above the middle; hands unequal in the male, index curving downward; many extremely minute teeth border the lateral margin of the carapax, and the upper edge of the feet; under 
side of the arm bordered by still larger teetli; a spine on the inner side of the carpus.

If the present species should prove distinct from the $\mathrm{P}$. dentata, it may be named $\mathrm{P}$. angustifrons, in contradistinction to the following, which we call

\section{P. latifrons. Mus. Acad.}

Testa depressa, transversè impressa, pone oculos incisa; fronte dilatata, margine multidentata.

Front between seven and eight-twentieths of the width of the carapax, truncate, and not divided into lobes by a superficial groove, as in the above species, its extremity somewhat folded beneath; orbits with a profound notch on the outer side; transverse impression of the carapax forming a gentle curve toward the middle instead of a nearly straight oblique line; median impressions subtriangular, large and profound; disk nearly smooth, or almost imperceptibly roughened, postero-lateral portion distinctly granulated; antero-lateral teeth somewhat unequal, and much larger than in the preceding species, those bordering the feet and arm nearly as in P. dentata; upper side of the arm and hand somewhat roughened.

Length of the only specimen in the collection (a female) hardly $I_{\frac{4}{10}}$ inches.

It is supposed to have been brought from Surinam, or the West Indies. 


\section{Fam. Gecarcinida.}

\section{Genus Orthostoma.}

Testa convexa, margine carinata, lateribus sub-obliquis, valde curvatis; fronte depressa, dentata, acuta ; fossis oculorum magnis. Maxillipedum articulo secundo intrinsècus producto; tertio internè exciso, apice acuto apùd angulum externum articulum quartum gerente ore quadrato: antennis externis brevibus profunde insertis, hiatum internum haùd implentibus.

Shell longitudinally convex, with the margin strongly carinate, and more or less toothed; sides of the body rather more oblique than in the neighboring genera, but far more vertical than in the Cancers; front depressed, having its edge thin, dentate, and not recurved; ocular pedicles not much elongated, cornea occupying only a small portion of their inferior side; ocular cavities very large, rather irregular, and leaving an extremely wide space at the internal angle; external antennæ very short, having their basal joint deeply seated, while the terminal ones do not fill up one-fourth of the orbitar hiatus; internal antennæ folded transversely in very narrow fossæ, which are almost concealed under the front; lateral pillars of the mouth straight; external appendage of the maxillary feet slender, but not linear, and bearing a rather long palpus at its extremity; second joint of the external maxillary feet produced antero-internally, having the base of the third lying, for the most part, on its outer side; third joint produced antero-externally, with the apex somewhat acute, VOL. VIII.-1839. 
and bearing the palpus on the inner side of the external angle; the arrangement is such that when the maxillary feet are brought together, the apices diverge, leaving between them a nearly semi-circular excavation; epistoma broad, and nearly on a line with the floor of the orbits; tail broad in the males, but extremely so in the females.

\section{O. dentata. Mus. Acad.}

Testa granulata, margine utrinque 10-dentata; fronte multidentata, obtuse bilobata.

Orbits of the eyes dentate inferiorly; regions of the carapax not very strongly defined, antero-lateral margin with ten teeth on each side; front greatly depressed, but not vertical, obtusely bilobate, and armed with fifteen or more small but sharp teeth; anterior feet moderately elongate; arm with one strong tooth on the under side; carpus slightly roughened, one strong tooth on its anterior inner side; hands unequal in both sexes, but especially so in the male, the right being largest; pincers carinate, large, and irregularly toothed, the large tooth being separated by several smaller ones; four posterior pairs of feet somewhat flattened; tarsi much flattened, and carinate both on their superior edge and laterally. Color reddish.

Length, as measured in four specimens, from $1 \frac{3}{4}$ inches to 2 inches.

Supposed to have been brought either fiom South America or the West Indies.

This species has, at first sight, much resemblance to the CaNCERS, owing to the breadth of its lateral crest. 
Fam. Ocypodide.

Genus Ocypode, (Fabr.)

O. rhombea, (Fabr.) Mus. Acad.

Two specimens, brought from the Sandwich Islands by Mr. J. K. Townsend.

Fam. Macropthalmida. Genus Macropthalmus, (Latr).

M. compressipes. Mus. Acad.

Manibus compressis, transverse carinatis; testa depressa, transversa, margine utrinque tridentata.

Ocular pedicles more than three-fourths as long as the whole width of the carapax, whose length is to the breadth as three to four in the males, but a little broader in the females; antero-lateral margin with three spines, the foremost one longest; feet flattened and bordered with long hairs; hands greatly flattened, broad, and inferiorly carinate on their external surface. Probably allied to M. carinimanus, (Latr.)

Sandwich Islands, J. K. Townsend.

Fam. Grapsida.

Genus Sesarma, (Say.)

S. recta. Mus. Acad.

Corpore quadrato, testa rugosa, antice convexa, margine carinata, utrinque pone oculos unidentata.

Carapax convex before the middle, and entirely 
covered with wrinkles, the anterior ones plicate, some of them bearing tufts of hairs ; median impression distinct; front vertical, profoundly four-lobed, lobes truncate, edge sinuous, profoundly excavated; epistoma granulous; bucc: and lateral regions of the body very strongly reticulate; anterior feet at least twice the length of the body, and very stont; arm with a notch on its upper edge; carpus with dense rugre, resembling rows of confluent tubercles; hand convex, very broad, less rough than the carpus, its upper edge quite sharp; pincers stout, with tuberculous edges, their prehensile side armed with unequal teeth; thighs of the four posterior pairs of feet with plicœ, extending upon the upper edge and giving it a somewhat dentate appearance, one tooth near the extremity; antepenultimate joint sulcate, the last a little hairy on its upper edge; tarsi long and sharp; striate with hairs.

Length about $1_{\frac{1}{1} \sigma}^{2}$ inches.

A single specimen, (a male,) labelled as brought from Surinam by Dr. Herring.

\section{Genus Grapsus.}

\section{G. hirtus, (Grapsé rude? Edw.) Mus. Acad.}

Testa depressa, striata, hirta, scabrosa, margine 2 -dentata, manibus parvis.

Front vertical, profoundly lobed, greatly produced, less than one-half as broad as the anterior portion of the shell; body entirely brown, with a few obscure spots; carapax depressed, scabrous, transversely striate, and covered with short, stiff 
bristles; margin with two teetl, placed as in G. pictus ; feet greatly flattened, with numerous transverse plica, lined each with hairs similar to those of the carapax, antepenultimate pair much longer than the rest, the anterior pair small, internal carpal tooth not dilated, but nearly spiniform.

The body is less dilated, more scabrous, and the front narrower and rather more produced than in G. pictus; the anterior feet are yet smaller than in that species, and the carpal tooth more spiniform.

Inhabits the Sandwich Islands; one specimen, (a male,) brought by Mr. Townsend.

\section{G. longipes. Mus. Acad.}

Testa striata, margine utrinquè 2-dentata; fronte tuberculosa; pedibus anterioribus elongatis, crassis, infrà valdè spinosis, carpis tuberculosis, manibus vix convexis, valdè dilatatis.

Shell of a pale flesh color, profoundly striate; sides less dilated posteriorly than in the G. pictus, (of authors;) antero-lateral margin bidentate, the anterior tooth nearly on the same line with the posterior; front vertical, occupying more than one-half the width of the carapax anteriorly, its surface with many large tubercles; anterior feet in the male nearly twice the length of the carapax, but only about one-half longer than the carapax in the female, armed on each side beneath with great spines; carpus covered with great spiniform tubercles; hands not very convex but greatly dilated, more or less roughened on the outer side, having spiniform 
tubercles on the upper and under side, and scattered tubercles on the inner; pincers stout, tuberculous on their outer edges and obtusely'dentate on their prehensile side; four posterior pair of feet greatly flattened; terminal joint with some long hairs; tarsi long, sharp, and very spinous.

Length, as measured in two specimens, about $1_{\frac{7}{10}}$ inches; supposed to have been brought from Surinam by Dr. Herring.

This species may, perhaps, terminate that section of the true Grapsi of M. Edwards, in which the third joint of the external maxillary feet is longer than broad; from these we will separate the following species of M. Edwards' second division, and place them in the

\section{Genus Pachygrapsus.}

Maxillipedum articulo tertio haùd longiore quàm lato, externè dilatato; fronte levitèr depressa; corpore quadrato vel posticè retracto; cœetera Grapso similis.

In these, the third joint of the external maxillary feet is as broad as long, more or less rounded on its outer side, and generally considerably dilated at its anterior inner angle, the front is not vertical, but simply inclined; the body is either nearly square or retracted behind; it is generally thicker, and its parietes firmer than in the GraPsi of the first division, and the anterior feet are usually very large and strong. 
P. crassipes. Mus. Acad.

Testa anticè convexa, transversè striata, utrinquè 2 -dentata; fronte producta, suprà 4-lobata; corpore crasso, posticè gradatim retracto.

Body very stout, carapax convex anteriorly, with two stout teeth on each side, including that which forms the outer angle of the eye; disk anteriorly and laterally striate, the striæ accompanied, for the most part, by yellowish lines; front considerably depressed, with four rounded lobes above, all very convex, and resembling great tubercles; frontal edge obtuse, rather prominent, nearly straight, a little sinuous near the angles; anterior feet nearly smooth and very large in the male; the surface of the carpus lightly rugose; four posterior pairs of feet much flattened; tarsi short, very stout and spinous.

Length about $1 \frac{6}{10}$ inches; greatest breadth between $I_{\frac{7}{1} \sigma}$ and $I_{\frac{1}{1} \sigma}^{8}$ inches.

A single specimen (a male) brought by Mr. Nuttall from the Sandwich Islands.

This species seems to be nearly allied to the Grapsus messor of Forskal, but the carapax in that species has but one lateral tooth.

\section{P. parallelus. Mus. Acad.}

Testa quadrata, striata, polita, convexa, margine utrinquè pone oculos 1-dentata.

Shell quadrate, nearly flat on the upper surface, lightly striate anteriorly, but very profoundly on the sides, where the striæ become plicate, some of 
them are produced quite upon the sides, in such a manner as almost to project from them; the margin presents only one tooth, which forms the outer angle of the orbit, and is quite stout, median impression of the carapax and lateral furrow on each side of it very profound; front moderately inclined, and not greatly prominent, divided into four quadrate lobes flattened above, frontal edge nearly straight, or lightly sinuous; hand only moderately large in the male and small in the female, more or less rough; four posterior pairs of feet polished, nearly smooth; tarsi moderately long, and terminated by a long, slender, corneous nail; the third joint of the outer maxillary feet is much rounded on. the outer side, and apparently somewhat concave. The color varies, but is usually yellow and brown mingled, minutely dotted with black; legs paler, dotted with black. Sometimes the whole body is pale yellowish or clay colored.

Length about $1 \frac{1}{4}$ inches.

The females seem to be more numerous and smaller than the males.

Several specimens, brought by Nuttall and Towrisend from the west coast, near the mouth of the Columbia river, and from the Sandwich Islands.

Genus Plagusta, (Latr.)

P. planissima, (CANCER planissima, Herbst.)

(P. clavimana, Desmarest.) Mus. Acad.

Brought from the Sandwich Islands by J. K. Townsend, but is larger than usually represented, being about $1 \frac{6}{10}$ inches in length. 
Fam. Calappiada.

Genus CALAPPa, (Fabr.)

C. tuberculata, (Fabr.) Mus. Acad.

Brought in great numbers from the Sandwich Islands by Nuttall and Townsend.

Fam. Leucosiada.

Genus Irta, (Leach.)

I. ornata. Mus. Acad.

Corpore globoso, vix granulato; testa polita, maculis sanguineis confluentibus, ornata.

Body globose; shell nearly smooth, with only a few granules anteriorly, some inconspicuous tubercles on the lateral edge, one large one on each side of the buccal regions; another, large but scarcely elevated, above it, and one, small but distinct, on each side posteriorly; two spines placed near each other at the apex, and one tubercle above them; disk variegated with sanguineous spots, confluent anteriorly; anterior feet variegated with red, about one-half as long again as the carapax in the female; arms granulous; epistoma dilated, leaving a considerable space between the eyes and the apex of the outer maxillary feet.

Length $1_{\frac{2}{10}}$ inches.

The description is made out from female speci mens, brought from Upper California by Mr. Nuttall.

voL. VIII. -1839 . 
Compared with $\mathrm{C}_{\text {ANCER }}$ punctatus, it is smaller, the body more smooth, more convex above, the spots greater and more confluent; the two lateral spines of the apex are nearer to one another than to the posterior feet, and the spine above them is reduced to a tubercle, or to two or three slight granules; moreover, the epistoma in C. punctatus is linear, and does not leave a considerable space between the eyes and the apex of the outer maxillary feet.

Decapoda Anomoura.

Fam. Raniniada.

Genus Ranina, (Lamarck.)

R. serrata, (Lam.) (R. dentata, Latr.) Mus. Acad.

Inhabits the Sandwich Islands, whence several specimens have been brought by J. K. Townsend.

Fam. Hippiade.

Genus Blepharipoda.

Testa ovato-oblonga; antennæ quatuor, elongatæ, inequales, ciliatæ, externis longioribus, revolutis; intermediis biappendiculatis. Pedunculi oculorum distinctè triarticulati. Pedes maxillarii externi elongati, involuti, articulo primo brevi, reliquis elongatis, tertio cylindrico, ultimo angustato, os non colantes. Pedes ciliati, angulati; duodidactyli antici.

Shell oblong-ovate, a little retracted behind; antennæ four, unequal, the external being much the 
greatest, with one long revolute appendage, which is ciliate on the outer side; the internal with two appendages, which are ciliate on the inner side, ocular pedicles exposed to their bases, and distinctly triarticulate; external maxillary feet involute, pediform, not closing the mouth, the basilar joint very stout, the rest longer, the third joint nearly cylindrical, and the terminal one subacute, external appendage produced nearly to the tip of the third joint, and rather strong; feet strong, ciliate, their bases approximate, their edges sharp, and the tarsi falcate, anterior pair extremely large at base, hands didactyle.

\section{B. occidentalis. Mus. Acad. PI. VI.}

'Testa polita, transverse impressa, lateribus utrinque 4-spi * nosis, fronte trispinosa.

Shell convex, somewhat obliquely elevated to ward the centre, which is faintly carinate; a median transverse sinuous impression, behind which the surface is polished, but anterior to it, densely marked with small transverse impressions, most of which are pectinated and hairy; a lateral transverse impression, and a very profound oblique one connected with it inferiorly; frontal edge strongly threetoothed, and excavated between the teeth; a distinct post-frontal transverse groove, behind which is a strong tooth; antero-lateral margin of the carapax with four stout teeth on each side; posterior margin excavated; second, third, and fourth pairs of feet 
more or less roughened laterally, and with the anterior edge minutely dentate; anterior pair stout; arm with a strong tooth near its anterior inferior extremity; carpus elongate, rather convex, laterally impressed, and having on its upper anterior edge a great spiniform crest, which is itself bordered with smaller spines; hand flattened on the side, and armed with two or three strong, sharp teeth, having between them a great multitude of impressions, similar to those of the carapax; pincers flattened, acute at tip and armed with sharp, spiniform teeth, both on their outer edges, and on their prehensile side.

Length about two inches, in the only specimen preserved in the collection, which was found by Mr. Nuttall at San Diego, in Upper California.

It may be considered as a connecting link between Ranina and Albunea.

$$
\begin{aligned}
& \text { Genus Hippa, (Fabr.) } \\
& \text { H. emeritus, (Fabr.) Mus. Acad. }
\end{aligned}
$$

Brought from the Sandwich Islands by Nuttall and Townsend, who describe it as being abundant there.

The Hippa talpoida, of Say, does not differ from this species.

Fam. Pagurida.

Genus Pagurus, (Fabr.)

P. punctulatus, (Edwards.) Mus. Acad.

Brought from the Sandwich Islands, by Messrs. Nuttall and Townsend. 
It inhabits the DouIum ringens, the Triton variegatum, and other large shells.

Average length of thorax, four to five inches.

P. deformis? (Edwards.) Mus. Acad.

A specimen, brought from the Sandwich Islands by J. K. Townsend, agrees with the description of this species by M. Fidwards, excepting that the second and third pairs of feet are tuberculous; if this should prove to be an invariable character, the present species may be named P. carinatus.

Length of thorax in the only specimen procured, rather more than $1_{\frac{1}{4}}$ inches.

\section{P. symmetricus. Mus. Acad.}

Pedibus cylindricis, manibus tuberculosis, $x$ qualibus, vix setosis, infrà valdè convexis, pedunculis oculorum gracilibus.

Eyes very small, scarcely one-fifteenth of the length of the ocular pedicles, which are somewhat three-sided, slender, rather long, being nearly twice as long as the basilar appendage of the external antennæ, though not so long as the anterior margin of the carapax, which is provided with a small, somewhat rounded rostrum; anterior feet equal, of moderate size, tuberculous above and beneath, but less so on their outer surface, hardly hairy, beneath very convex and forming, laterally, nearly a straight line with the fingers, which, for a considerable distance at their extremities, unite by a black margin, and, when closed, form a nearly oval body; second and third pairs of feet long, slender, cylindrical, 
somewhat rugose, but hardly tuberculous, and marked, together with the tarsi, which are at least one-fifth longer than the preceding joint, with tufts of short hairs, or with depressions, from which the hairs have been removed; these depressions sometimes form an interrupted sulcus on the upper side of the tarsus. Color yellowish; length of carapax rather more than an inch, but perhaps becomes larger by age.

It is labelled as having been brought by Dr. Herring from Surinam, and may, perhaps, be allied to P. oculatus, (Fabr,) and to P. crassimanus, (Edw.) it has much resemblance, in form, to the P. Labitlardieri, (Savigni, Egypt, Crust., Pl. 9, fig. 2.)

A small specimen, evidently of the same species, is preserved in the collection, labelled as having been found in the East Indies by J. Longstreth.

\section{P. decorus. Mus. Acad.}

'Testa polita, profundè punctata, fronte rostrata, manibus ferrugineis, tuberculosis, apicé digitorum albo, pedibus annulis coccineis cinctis.

Anterior portion of the thorax longer than broad, front with a very small rostrum; eyes extremely small, pedicles slender, bluish, rather longer than the anterior margin of the shell, and more than twice as long as the appendage of the external antennæ; carapax bluish, with numerous large punctures, having their cavities pale; antennæ bright orange; anterior feet dark reddish, carinate above, with somewhat short, triangular, very unequal hands studded with white tubercles; the fingers 
white at tip; two following pairs of feet compressed, black or dark red, with the articulations of the joints bright vermilion; the tarsi short, stout, color bright vermilion, marked with black spots, from each of which grows a small tuft of hairs; the under side of the tarsus sometimes very densely tufted with long, thread-like, pinkish hairs.

Length one inch to $1 \frac{1}{2}$ inches.

Found by Mr. Nuttall at the Sandwich Islands, inhabiting the shells of various species of TurBo.

Probably allied to the P. chilensis, (Edwards,) and to the following:

P. elegans, (Edwards.) Mus. Acad.

Specimens, apparently of this species, brought by Mr. Nuttall from the Sandwich Islands.

Two other small species of PAGURus, allied to the above, have been brought also from the Sand.wich Islands by Mr. J. K. Townsend, the first may be named

\section{P. lavimanus. Mus. Acad.}

Having the hands entirely smooth, pink above and white beneath, the right very large; legs reddish, tarsi paler, with a red spot on each side. The ocular pedicles are about the length of the anterior margin of the carapax.

The following may be called

P. latens. Mus. Acad.

In which the ocular pedicles are rather longer 
than in the preceding, and the anterior feet granular; right hands with a sharp dentate crest on the upper side. Color bluish or reddish, the feet in some banded alternately with blue and red.

\section{Genus Cenobita. (Latr.) \\ C. Diogenes. (Auctorum.) Mus. Acad.}

A specimen of this species was brought by Mr. Nuttall, supposed to have been found at the Sandwich Islands.

Fam. Porcellaniada.

Genus Porceliana, (Lam.)

P. cinctipes. Mus. Acad.

Testa polita, anticè levitèr granulata, posticè levitèr striata; fronte canaliculata, pedum pare antico granulato, carpis unispinosis; reliquis albo-fasciatis.

Shell obtusely hexagonal, about as long as broad, exclusive of the front, which is triangular, prominent, profoundly canaliculate, and presenting on each side at base the germ of a dentiform lobe; carapax punctured in the middle, granular anteriorly, and striate on each side posteriorly, sides surrounded by a very prominent crest; color reddishbrown anteriorly, blue postero-laterally; anterior feet granular above, smooth, and highly polished underneath, carpus with a prominent ridge near the outer edge, terminating in a tooth; inner extremity only a little crenate; hands triangular, outer edge sharp; three posterior pairs of feet flattened, their color blue, fasciate with white. 
Length a little over six-tenths of an inch.

Brought by Mr. Nuttall from the Sandwich Islands.

Decapoda Macroura.

Fam. Scillaride.

Genus Scillaarus, (Fabr.)

S. latus, (Latr.) Mus. Acad.

Two specimens, brought from the Sandwich Islands by Messrs. Nuttall and Townsend.

Genus Ibacus, (Leach.)

I. antarcticus, (Fabr.) Mus. Acad.

Several specimens, taken with the preceding at the Sandwich Islands, by Messrs. Nuttall and Townsend.
Fam. Palinurida.
Genus Paimnurus, (Fabr.)
P. interruptus. Mus. Acad.

Testa antice spinosa, postice tuberculata; epistoma 7-spinosa; fronte bicorni abdominis segmentis interruptè sulcatis; pedibus vittatis.

Thorax with large spines anteriorly, and large flattened tubercles posteriorly, and armed in front with two very stout horns, having their apices subapproximate; epistoma with seven spines, the mid. dle one largest; spaces between the thoracic spines and tubercles depressed and hairy; joints of the external antennæ covered with large spines; oph voL. virr. - 1839 . 
thalmic ring armed above with four spines, placed two and two, the anterior pair being larger than the others; abdomen with obsolete, minute spots, and scattered punctures; segments each with a profound, hairy, transverse sulcus, not reaching the middle, excepting on the last segment, where it is scarcely interrupted; feet vittate alternately with red and olivaceous.

Length from five to nine inches, as measured in two specimens, brought by Messrs. Nuttall and Townsend from Upper California, where it is used as food by the natives.*

It is probably allied to the P.Argus, (Latr.,) and to P. dasypus, (Latr.)

Fam. Astacida.

Genus Astacus, (Fabr.)

A. oreganus. Mus. Acad. Pl. VII.

Testa granulata, bimaculata, fronte valde producta.

Body fuscous, granulated, carpus with a sharp spine at the interior inner angle; arm produced into a spine on each side anteriorly; thorax behind the front with five spines, placed three before, and one on each side behind the lateral ones; a large reddish spot on each side posteriorly; front little reflexed on the sides, terminating in a very long, slender spine, and having a short, marginal spine on each side.

Length about four inches.

* Since the above description was written, Mr. Nuttall informs me that he has found specimens of this species two feet in length. 
Taken by Mr. Nuttall in the Columbia river, west coast of North America.

\section{Genus Nerhrops, (Leach.) \\ N. occidentalis. Mus. Acad.}

Thorace lanuginoso, spinis in serie triplici dispositis; manibus prismaticis, villosis.

Thorax downy, armed above with three rows of strong spines, the middle row commencing behind the others, and composed of five or six teeth ; the lateral rows have also about six teeth, and are continued upon the base of the rostrum, but terminate within the point at which the marginal spines of the front commence; these latter are in number four on each side, and a terminal one common to both; parallel with the fifth spine of the lateral thoracic row, and on the outer side of it, is a strong spine, almost imperceptibly cleft at base; no tubercles are visible on any part. Anterior feet very spinous above, and underneath; hands somewhat prismatic, with from three to five rows of tubercles, more or less spiniform on both the inner and outer face, the lateral ones ill defined, but the middle row very distinct; the left hand is rather the larger, and the upper and under surface of both, together with the prehensile side of the pincers, and almost the whole surface of the maxillary feet covered with very long, coarse hairs; segments of the abdomen sculptured as in the $\mathbf{N}$. norvegicus.

Length half a foot.

Brought from the west coast of North America by Mr. Nuttall. 
Fam. Alpheida.

Subgenus Atroida.

Pedum pare tertio elongato, gracili, cœtera Atyæ similis.

It is essentially similar to the genus ATYA, of Leach, excepting the third pair of feet, which are elongate, gradually retracted toward the apex, and scarcely stronger than the two anterior pairs; the terminal joint is not broader at its extremity than the base of the tarsus.

\section{A. bisulcata. Mus. Acad. Pl. V., fig. 5.}

Testa polita, transverse sulcata, margine anteriori utrinquè bispinosa, rostro producto, valde acuto, utrinquè bisulcato.

Maxillary feet not attaining the extremity of the basal scales of the external antennæ, which are densely clothed with black hairs at their extremities, and greatly exceed the peduncle of the internal antennæ; thorax smooth, with a transverse sulcus behind the middle; a spine on the anterior margin of the thorax, between the rostrum and the outer angles, which are also produced into a spine; rostrum commencing from the base of the front, produced to a yery fine point, and having a profound sulcus on each side; the front is so much elevated on its margin, that the two sides, together with the rostrum, present, at first sight, the appearance of a triple carina; terminal appendages of the abdomen smooth.

Jength about one inch. 
Brought by Mr. Nuttall from the Sandwich Islands.

Genus $\Lambda$ LpHevs, (Fabr.)

A. Zrevirostris? (Edw.) Mus. Acad.

Dr. Burroughs has brought from Manilla a species of Alpheus, agreeing with M. Edwards's description of A. brevirostris, with this exception, that it has a distinct tooth on the outer side of the basilar article of the external antennæ; there is also a somewhat elevated ridge on the outer side of the arm. I have named it, provisionally, A. dispar.

Another species of ALpheus has been brought from the Sandwich Islands by Mr. Nuttall, in which the orbitar arches are considerably produced, and armed each with a short slender spine; the external side of the basal article of the external antennæ is continued into a sharp tooth; the rostrum is short, entire, and very pointed; the second article of the internal antennæ is about one-half longer than the first; the carapax is entirely smooth; hands smooth, the right one largest, the fingers very short, the moveable one very obtusely rounded.

Length about $1 \frac{1}{2}$ inches.

I have named this species A. lovis. Mus. Acad.

Fam. Palemonidce.

Genus Hippolyte, (Leach.)

H. marmoratus, (PALEmon marmoratus, Oliv.) Mus. Acad.

Several specimens, brought from the Sandwich Islands by Mr. Nuttall. 
The maxillary feet of the female are scarcely one-half the length of those in the male.

Another species of Hippoly'te, brought also by Mr. Nuttall from the Sandwich Islands, may be named H. gracilipes.

The whole surface of its body is roughened; the thorax is furnished with a slightly elevated crest, commencing behind the middle of the carapax, and extending upon the rostrum, which is greatly compressed and produced downwards on the under side; the thoracic crest is armed with three or four spines behind the rostrum, and the rostrum itself with seven or eight; on its under side are a few long hairs, but no teeth; external maxillæ only of moderate length ; feet slender, second pair elongate; the carpus long, nearly cylindrical, greatly inflated toward the base, but greatly contracted at the point of the commencement of the fingers, which are as long as the carpus, very slender and slightly curved; abdomen extremely gibbous.

Length nearly $\mathbf{1}_{\frac{1}{2}}$ inches. Mus. Acad.

\section{Genus Palemon, (Fabr.)}

P. grandimanus. Mus. Acad.

Thorace subcylindrico, rostro compresso, 15-dentato squamas antennarum æquante, antrorsum vix descendente; pedum pare secundo longissimo, minutè spinoso, digitis modò in apice attigentibus.

Thorax nearly cylindrical, with a strong tooth on each side, and another scarcely visible behind it; rostrum greatly compressed, dilated, almost straight, 
and as long as the squamous plate of the external antennæ, armed with fifteen teeth on the upper side and with four beneath; second pair of feet very unequal, the left being considerably longer than the body; both are densely covered with almost invisible spines and close down; carpus about two-thirds of the length of the hand, very small at base, but gradually enlarging anteriorly; the left hand very large, being three times as thick as the arm, and considerably inflated; pincers about as long as the hand, and when closed leave a great space between their prehensile sides, which are armed each with one or more great teeth, and with as many smaller ones at base, their outer sides are marked with some black spots, more or less distinct; four posterior pairs of feet short and slender; eyes white.

\section{Length about $2 \frac{1}{2}$ inches.}

Length of the left foot of the second pair, $3 \frac{1}{4}$ inches.

Brought by Messrs. Nuttall and Townsend from the Sandwich Islands.

\section{P. gracilimanus. Mus. Acad.}

Rostro 13-vel 14-dentato, recto, squamis antennarum longiore; testa polita, utrinquè bispinosa; pedum pare secundo elongato, gracilibus, manibus verrucosis.

Rostrum rather broad, compressed, straight, but directed a little upwards at tip, a little longer than the basal plates of the antennæ, armed on the upper side with about thirteen teeth, and beneath with five or six serratures; a strong spine on each side the thorax, and a very small one behind it; second 
pair of feet equal, nearly as long as the body rostrum inclusive, very slender, more or less tuberculous, or at least roughened; the carpus one-third longer than the hand, which last is a somewhat. flattened cylinder, covered with minute tubercles, disposed in longitudinal rows, more or less distinct; pincers less long than the hand, uniting in their basal half, but leaving a slight space between them in their apical half.

Length from tip of rostrum to extremity of caudal appendages, about $3 \frac{1}{2}$ inches.

Length of second pair of feet nearly three inches. Found by J. K. Townsend at the Sandwich Islands.

The following species of PaLEMon differs from the P.jamacenisis in the second pair of feet, which are greatly longer than in that species, and more spinous; neither does it well agree with the P. Lar, (Fabr.) which Olivier says has a smooth thorax, moreover, the rostrum does not, in the present species, attain the extremity of the basal scales of the external antennæ by one-fourth; it differs in nearly these same respects from the P. longimanus, (Fabr.) which has the pincers smooth, according to Olivier, (Encyc. Meth.) The P. ornatus has only eight or ten teeth on the upper side of the rostrum, and the carpus is nearly the length of the palmar portion of the hand, and the feet, except the second pair, are nearly smooth; the same is the case with the $\mathrm{P}$. forceps, (Edw.)

The following description will better determine its relationship. 
Palemon testâ politâ, lateribus profundè punctatis, rostro squamis antennarum breviorc, antrorsum descendente, 12-vel 13 spinoso; pedum pare secundo longissimo, spinoso, cylindrico.

Rostrum longer than the pedunclc of the external antennæ, but not so long as their basal scales, somcwhat descending anteriorly, and armed with twelve or thirteen tecth above, and three beneath; thorax smooth, except on the sides where it is almost reticulate with profound puncturcs; a strong spine on each side anteriorly, and a smaller one behind it; second pair of feet longer than the body, inclusive of the rostrum and caudal appendages, and covered in thcir whole extent with strong spines, those on the under side being largest, many of them nearly one-eighth of an inch in length; carpus scarcely three-fifths of the length of the palmar portion of the hand; pincers at least as long as the hand, very spinous, white at tip, wherc they are strongly crooked, the moveable one is armed with two or three small teeth, and the immovable with one; the two unite in their wholc length, being formed much as in the P. carcinus, but in the specimen belonging to the Academy, which has only the foot of the right side remaining, they accidentally diverge; the carina, however, together with the groove which should receive it, are somewhat distinct; the remaining feet are all covered more or less with short spines.

Length eight inches, but perhaps becomes larger with age.

voL. vir1. -1839 . 
It is supposed to have been brought from the East Indies by Dr. Burrough.

The second pair of feet are stronger than in the P. carcinus, and far more spinous. I liave named it P. punctatus. Mus. Acad.*

Genus Penaus.

P. canaliculatus, (Oliv.) Mus. Acad.

Many specimens, of a species agreeing with Olivier's description of this species, excepting that the rostrum is armed beneath with two teeth, instead of one, have been brought from the Sandwich Islands by Messrs. Nuttall and Townsend. The carapax is black, and bordered on each side behind with white; there are no spines at the base of the third pair of feet; the rostrum is armed with only nine teeth.

Length four to five inches.

If distinct from Olivier's species, I will name it P. marginatus.

\section{Crustacea Stomapoda.}

Fam. Squilliada.

Genus Squilla, (Rondelet.)

S. arenaria, (Rumph. et Herbst.,) (S. maculata, Lamarck.) Mus. Acad.

Inhabits the Sandwich Islands, whence specimens have been brought by Mr. J. K. Townsend.

* I have, since writing the above, scen another specimen of this species, brought from the West Indies. 
S. nepa, (Latr.) Mus. Acad.

Brought also from the Sandwich Islands by Mr. J. K. Townsend.

S. stylifera, (Lam.) Mus. Acad.

Brought in considerable numbers from the Sandwich Islands, by Messrs. Nuttall and Townsend.

Genus Gonodactylus, (Latr.)

G. styliferus, (Edwards.)

A single specimen of this species has been brought from the Sandwich Islands by Mr. Townsend; the color of the hands is bright blue.

Reference to Plates accompanying the Paper.

Plate III. Epradtus Nuttallii, page 109.

“ IV. Trialayita pulclira, page 117.

"V. Fig. 1, 2, and 3. Onтmostoma dentata, page 122.

"6 Fig. 4. Pacitygrapsus, pago 126.

" " Fig. 5. ATroIda bisulcata, page 140.

“VI. Befmentiodon oceidentalis, page 131.

“VIT. Astacus oreganus, page 138. 
Description of a Nerv Species of Cypceius, from the Columbia River. By Jorn K. Townsend.

Read March 5th, 1839.

\section{Cypcelus Vauxii.}

BiLt slender, black; upper parts of a dull smokebrown, inclining to blackish upon the interscapular region; shoulders and primary quills blackish; the rump and tail are of a much lighter color than the back, being dull cinereous-brown; shafts of the tailfeathers, and their points, black; wings of ordinary length, extending about two inches beyond the tail; throat, and upper portion of the breast, grayish-white; belly, and all below, cinereous-gray. Legs and feet brownish-black. Irides dark hazel. Length $3 \frac{1}{2}$ inches. Extent of wings 10 inches. It differs from the C. pelasgius, with which it has been confounded, in several very striking particulars. It is one inch shorter, and two inches less in extent; the body is proportionably smaller in every aspect, and the color much lighter.

This species (which I dedicate to my friend, Wm. S. Vaux, Esq., of Philadelphia) is common on the Columbia river; breeds in hollow trees, forming its nest in the same manner as the pelasgius, and lays four white eggrs. 
Description of a Nen Species of SYLuIA, from the Columbia River. By Jonn K. Townsend.

Read April 2d, 1839.

Sylvia Tolmai, 'Tolmie's Warbler. Audubon's Birds of America, Vol. IV., pl. 399, male and female. (S. phitadelphia in the plate.)

The bill is brownish above, pale flesh-color beneath, darker at the point; lores, and narrow frontlet, black; whole head, neck, and upper part of the breast, dark sooty-ash, the feathers of the latter fringed with white; upper parts greenish-yellowolive; the tail brighter, and of a uniform color, without spots; wings lightish-cinereous, the exterior vanes of all the feathers, including the coverts, yellow. Legs and feet flesh color. Length 5 inches. Extent of wings $6 \frac{1}{2}$ inches.

The female differs from the male, chiefly by having the head and throat light ash color, without any black, and in being destitute of the black frontlet and lores.

This pretty species, so much resembling the curious S. philadelphia, of Wilson, is common in spring on the Columbia. It is mostly solitary, and extremely wary, keeping chiefly in the densest and most impenetrable thickets, and gliding through them in a very cautious and suspicious mauner. It may, however, sometimes be seen, towards mid-day, perched upon a dead twig, over its favorite place of concealment, and at such times it warbles a sprightly and pleasant little song, raising its head until the 
bill is almost vertical, and swelling its throat in the manner of its relatives.

I dedicate this species to my friend W. F. Tolmie, Esq., of Fort Vancouver.

\section{An Analysis of Marl from New Jersey. By S. S. Haldeman.}

Read May, 1839.

I TAKE this opportunity to forward an analysis of a specimen of the peculiar concretions found in the New Jersey greensand. Some of these are tubular, having been formed, or concreted, (as I discovered,) around vegetable fibre, or lignite. The greensand itself frequently occurs in the same manner.

Mineral Characters.-Color bluish-white on the surface; light chocolate upon a fresh fracture; soft, and easily broken; generally irregularly cylindrical, sometimes tubular. The surface covered with grains of greensand.

\begin{tabular}{|c|c|c|}
\hline \multicolumn{3}{|c|}{ Analysis, (a single trial.) } \\
\hline Silica, & & 82.09 \\
\hline Alumina, & & 9.10 \\
\hline Oxide of Iron, & . & 1.31 \\
\hline Water, & & 5.65 \\
\hline Volatile matter, & & 1.85 \\
\hline
\end{tabular}


List of the Birds Inhabiting the Region of the Rocky Mountains, the T'erritory of the Oregon, and the North West Coast of America. By JoHN K. Townsend.

Read September 10th, 1839.

The species recently discovered and described, are designated by an*. Those which have been seen, but not characterized, are marked thus $\$$.

\section{LAND BIRDS.}

Cathartes californianus.

"aura.

Falco sparverius.

" columbarius.

" albicilla?

" leucocephalus.

" haliatus.

" fuscus.

" borealis.

" cyaneus.

" peregrinus.

" lagopus.

" osalon.

" buteo.

" hyemalis.

" Cooperii.

" sancti-johannis.

STRIX asio.

" navia.

“ virginiana.

" cinerea. 
TOWNSEND'S BIRDS.

STRIX brachyotus.

" acadica.

"otus.

"Tengmalmi.

". cunicularia.

" passerinoides.

Sturnus ludovicianus.

ICTERUS phoniceus.

" zanthrocephalus.

"Bullockii.

"* $\quad$ tricolo, (Aud.)

"* * gubernator.

QuiscauUs ferrugineus.

Corvus corax.

" americanus.

" ossifragus.

" pica.

"Nucifraga) columbiana.

Garrulus Stelleri.

"ultramarinus

" canadensis.

Parus atricapillus.

" * rufescens, (Towns.)

" * minimus, (Towns.)

Bombycilla carotinensis.

LaNius borealis.

"ludovicianus.

Muscicapa tyrannus.

" Cooperii.

"verticalis.

"Saya.

"fusca. 
TOWNSEND'S BIRDS.

Muscicapa virens.

$\begin{array}{ll}\text { " } & \text { pusilla, (Sw.) } \\ \text { " } & \text { Traillii. } \\ \text { " } & \text { Richadica. } \\ \text { " } & \text { nigricans, (Sw.) }\end{array}$

ICTERIA viridis.

VIREO solitarius.

"gilvus.

" noveboracensis.

Ptiliogonys * Townsendii, (Aud.)

TuRdus migratorius.

" navia.

" minor.

"Wilsonii.

" aurocapillus.

" \$Tonnsendii, (Aud.)

" (orpheus) *montonus, (Towns.)

" nanus, (Aud.)

Cincuus americanus, (Sw.)

Sylvia astiva.

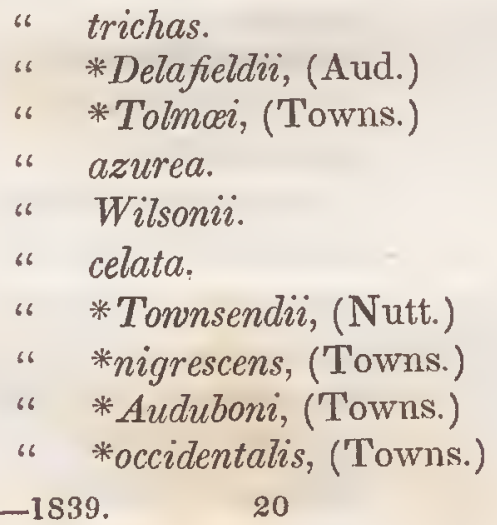


Regulus calendula.

“ cristatus.

Troglodytes fulvus.

"Bewickii.

" * Parkmanii, (Aud.)

Myiothera obsoleta.

Sialia arctica, (Sw.)

“ *occidentalis, (Towns.)

Anthus spinoletta.

Alauda cornuta, (Wils.)

Emberiza nivalis.

" pallida, (Sw.)

TANagra ludoviciana.

Fringilla * Mortoni, (Aud.)

\begin{tabular}{|c|c|}
\hline “ & amcena, (Say.) \\
\hline “ & leucophrys. \\
\hline “ & graminea. \\
\hline “. & socialis. \\
\hline “ & tristis. \\
\hline “ & pinus. \\
\hline ، & purpurea. \\
\hline " & arctica. \\
\hline " & *oregona, (Towns.) \\
\hline " & atricapilla, (Gm.) \\
\hline “ & cinerea, (Gm.) \\
\hline “ & *Tonnsendii, (Aud.) \\
\hline “ & canadensis. \\
\hline “ & vespertina. \\
\hline “ & grammaca. \\
\hline "، & maculata. \\
\hline "6 & pusilla. \\
\hline " & *chlorura, (Aud.) \\
\hline
\end{tabular}


Fringilla * bicolor, (Towns.)

“ (plectrophanes,) *ornata, (Towns.)

" savanna.

Loxia curvirostra.

Coccyzus americanus.

Picus mexicanus.

" pileatus.

" imperialis.

" spyrrhonotus, (Aud.)

" torquatus.

" lineatus.

" ruber.

" * Harrisii, (Aud.)

" * Gairdnerii, (Aud.)

SITTA carolinensis.

" canadensis.

CERTHia familiaris.

Trochilus rufus.

"6

anna.

Alcedo alcyon.

Hindndo purpurea.

" fulva.

" bicolor.

" riparia.

" thallassina.

"rufa.

Cypselus $*$ Vauxii, (Towns.)

CAPrimulgus virginianus.

" $\quad \$ N$ Nuttallii, (Aud.)

Columba migratoria.

" fasciata.

" carolinensis. 
Perdix plumifera, (Gould.)

Tetrao umbellus.

" obscurus.

" urophasianus.

" canadensis.

" phasianellus.

" leucurus.

Phasianus §americanus, (Aud.)

\section{Water BiRds.}

Hamatopus * Tonnsendii, (Aud.)

$$
\text { " *Bachmanii, (Aud.) }
$$

Charadrius vociferus.

$$
\text { " } \quad \text { montanus, (Towns.) }
$$

GRUs americana.

ARdea herodias.

" nycticorax.

RecURVIRostra americana.

Numenius longirostris.

" borealis.

Tringa alpina.

"Wilsonii.

" semipalmata.

Totanus macularis.

" flavipes.

" semipalmatus.

Aphriza * Tonnsendii, (Aud.)

Limosa fedoa.

Scolopax Wilsonii.

" Drummondii. 
Scolopax grisea.

Rallus carolinus.

Furica americana.

Phalaropus Wilsonii.

" hyperboreus.

" fulicarius.

Podiceps minor.

$$
\text { fulicarius. }
$$

"rubricollis.

Sterna nigra.

Larus canus.

"*occidentalis, (Aud.)

Thalassidroma Wilsonii.

16 Leachii.

Proceliania gigantea.

" *pacifica, (Aud.)

" *tenuirostris, (Aud.)

Diomedea * fusca, (Aud.)

" * chlororhynchos, (Aud.)

" *nigripes, (Aud.)

ANser hypoboreus.

" albifrons.

" canadensis.

"Hutchinsii.

CyGnus americanus, (Sharpless.)

"buccinator.

Anas boschas.

" americana.

"sponsa.

" crecca.

" clypeata.

" obscura.

"acuta. 
Fuligula perspicillata.

$$
\begin{array}{ll}
\text { " } & \text { marila. } \\
\text { " } & \text { valisneria. } \\
\text { " } & \text { histrionicica. } \\
\text { " } & \text { clangula. } \\
\text { " } & \text { glacialis. } \\
\text { dispar. }
\end{array}
$$

Mergus merganser.

" cucullatus.

Penecanus onocrotalus.

66

$$
\text { fuscus. }
$$

Phalacrocorax *splendens, (Towns.)

$$
\begin{array}{ll}
\text { " } & \text { *Tonnsendii, (Aud.) } \\
\text { "Sleucurus, (Aud.) } & \text { sleuconotus, (Aud.) }
\end{array}
$$

Corymbus glaciatis.

URIA *Tonnsendii, (Aud.)

"grylle.

‘. antiqua.

Phaleris nodirostris.

" cristatella.

Ceratorhyncha occidentatis. 
Note on Sylvia Tolmoi. By John K. Townsend.

Read September 10th, 1839.

WHEN I first procured this bird on the Columbia River in the spring of 1835 , I considered it an undescribed species, and have never since seen reason to renounce the opinion then formed. Specimens, in several varieties of plumage, were sent by me to the Academy in the following year, from among which Mr. Audubon selected several. A pair of these are figured in the 4 th volume of his splendid work, under the title of Sycvia philadelphia, for which species Mr. A. always mistook it.

Being myself thoroughly convinced, that this usually accurate naturalist was for once mistaken, I. ventured to insert a description of this bird in an appendix to my recently published work, "Narrative of a Journey Across the Rocky Mountains, \&c." and honored it with the name of my friend Dr. W. Fraser Tolmie. At a subsequent period, Mr. Audubon, aware of his former error, relinquished the name of S. philadelphia, and in Vol. V. of his "Ornithological Biography," page 75, called the species S. Macgilivrayi.

If I had been aware, before the publication of my appendix, of Mr. Audubon's wish to name this bird, I should have adopted his appellation with cheerfulness; but as his intention was never communicated to me, the name of S. Tolmai, which I have given it, having priority, must of course be retained. 
Description of the White-winged Tanager, (Pyranga leucoptera.) By J. Trudeau.

Read June 4th, 1839.

Bill shorter than the head, convex, hard, of a bluish-black,-above and below of a rich crimsonred; anal region paler; a band of deep black around the bill and eyes. Wings and tail black; on the former two white bands. Primaries (the first is shorter than the second and third, which are the longest) edged with pale ash. Secondaries tipped with white. Inside of the wings of a pure white. Tail slightly rounded. Tarsi shorter than the middle toe, of a bluish-black, and about eight lines long. Length five inches nine lines. Iris hazel. From Mexico. No information of its habits. 
Description of a Species of Land Tortoise, from Africa. By Edward Hatloweld, M. D.

The genus Kinixis, the most remarkable among the family of land tortoises, was established by Mr. Bell, in 1827. The most striking character in this genus consists in the mobility of the posterior portion of the carapace, which may be brought at will in contact with the sternum. This motion is not effected through the agency of a ligamentous hinge, as is the case in the Chelonians. with a moveable sternum, but exists chiefly in the bony structure itself, which is nearly diaphanous, and, in the living animal, possesses a certain degree of elasticity.

A living specimen of this genus was recently received from Liberia, by my friend, Dr. Blanding, to whom I am indebted for the opportunity of describing such portions of it as remained unnoticed, and also of correcting an error respecting the line of flexion of the carapace, the position of which, in the dead animal, cannot well be determined.

\section{Kinixis.}

Generic Characters.-Carapace moveable posteriorly; anterior extremities with five toes, posterior with four only; sternum immoveable.

Kinixis denticulata, (Pls. VIII and IX.)

Characters.-Carapace oblong ovate, rounded and voL. v111, -1839 . 
broader posteriorly; free margin strongly denticulated; sides carinated; no nuchal plate; supra caudal single.

SYNONYMES.

Testudo denticulata, (pullus,) Shaw, Gen. Zool., Vul. III, p. 59, pl. 13.

Testudo erosu, Schweigg., Prodrom., Archiv. Kønig., tom. I, p. 321.

Kinixis castaneu, Bell, Linnæan Transact., Vol. XV, p. 392, pl. 17, fig. 1 .

Kinixis erosu, Gray, Synop. Reptil., p. 16.

Kinixis erosa, Dum. et Bibr., tom. II, p. 165.

Description.-The head is long, somewhat depressed; the inferior margin of the upper jaw is slightly incurvated, presenting a sharp cutting edge ; the lower jaw is also sharp and cutting, and terminates anteriorly in a slight hook, concealed within the margin of the upper jaw, when the mouth is closed. The upper surface of the head is covered with small scales posteriorly, and larger plates in front; the latter are six in number, viz. : one rostral, two fronto-nasal, two frontal, and one vertical plate; the rostral plate is small and triangular, its apex pointing backwards; the fronto-nasal are of moderate size, irregularly pentagonal, somewhat prolonged posteriorly; their inner margin on a line with the corresponding margins of the frontal plates; the frontal are large and pentagular, slightly convex above, their anterior and internal margins forming a right angle; the vertical plate is large and angular in front; its lateral and posterior margins are very irregular. Tympanum large; nos- 
trils large and wide apart; the eyes are of moderate size, somewhat projecting, and have a mild expression. The neck is of moderate length, and presents a minutely granulated surface.

The anterior extremities are large and compressed, covered with scales and large trihædral tubercles anteriorly, and with scales and granulations posteriorly; the tubercles, which are nine or ten in number, are arranged in longitudinal and somewhat irregular rows; four or five are placed along the superior and anterior margin of each extremity; one of them is much larger than the rest, and terminates in a sharp point; the intermediate row consists of two, sometimes three tubercles, the most inferior of which is the largest; of those situated along the inferior margin, two are remarkably large, corresponding nearly in size with the most inferior of the middle row; besides these, there is a smaller tubercle placed at the internal angle of each elbow. The posterior extremities are of moderate size, slightly compressed, sub-clavate, terminating in four toes, each furnished with a strong, and slightly incurvated nail, the two middle the longest; they are covered with numerous polygonal scales, of nearly equal size anteriorly, larger upon the soles of the feet, upon the posterior surface of the leg, and along the posterior margin of the carpus, where they assume the form of tubercles. Tail rather long and compressed, broad and thick at base, pointed at tip, covered with small scales.

The shell is oblong-ovate, somewhat depressed, brouter and gibbous posteriorly; elongated and tecti- 
form in front, its free margin strongly denticulated; the posterior margin of the sternum and carapace more or less eroded from frequent contact; of the five vertebral plates, the first is pentagonal, broader in front, having its anterior angle pointed; the second, third, and fourth, are hexagonal; the fifth is quadrilateral, having its basis rounded, and joined to five of the marginal plates; in its centre is a marked protuberance, corresponding in situation with the area; the first costal plate is trapezoidal, elongated and rounded anteriorly, its superior margin, where it joins the second vertebral plate, much the smallest; the second is pentagonal, sometimes heptagonal, the third is pentagonal, the fourth is trapezoidal; the marginal plates are twenty-three in number, viz.: eleven on each side, and a supracaudal, which is single; the first marginal plate is broad and quadrilateral, the second and third are triangnlar, having their bases rounded, and their apices truncate; these plates are turned slightly upwards at their outer margins, hence their upper surface appears somewhat concave; the fourth, fifth, sixth and seventh, are more or less quadrilateral in shape, longer in the vertical than in the antero-posterior direction; they are each distinctly carinated. The marginal plates which belong to the moveable portion of the carapace, are nine in number ; of these, the first is small and somewhat triangular, the base presenting upward, and the apex, which is obtuse, downward. The remaining plates are irregularly quadrilateral, having their outer margins everted, or turned upward towards the disk; the supra-caudal is large, 
and more extended in the transverse than in the vertical direction. The upper surface of each of these plates is strongly marked with concentric strix; they each present a granulated area, which, in the vertical plates, is central, but in the costal approximates more or less to their superior margin; those of the remaining plates of the disk are placed along its marginal outline. The vertebral plates are indistinctly carinated. The moveable portion of the carapace comprises that portion of it which is covered by the two last vertebral plates, the last costal pair, and the nine posterior marginal plates; the line of flexion, therefore, passes between the seventh and eighth marginal, the interval between. which is filled up with a sort of fibro-cartilaginous substance, the third and fourth costal, and the third and fourth vertebral plates. The sternum is large, emarginate in front, rounded posteriorly; the gular plates are triangular, their apices presenting backwards; the brachial are large and quadrilateral, rounded externally, their anterior margin the smallest; the thoracic are broad and pentagonal, presenting an obtuse angle anteriorly; the abdominal are very large and quadrilateral, being joined externally to two of the marginal plates, and to the anterior and inferior margin of the inguinal plate; the femoral are trapezoidal, their anterior and internal margin forming a right angle, the internal margin is much the smallest; the subcaudal are small and triangular; the axillary plates are small, and almost concealed within the shell; their outer surface is triangular, the apex pointing upward and 
backward. The wings are long, extending from the fourth to the seventh marginal plate inclusively. The anterior portion of the sternum is thick and strong, constituting a firm support for the neck of the animal; it projects half an inch beyond the carapace.

Colour.-Head above light straw-colour, with a slight tinge of orange upon the rostral and frontonasal plates. Upper jaw light horn-colour anteriorly, with a tinge of orange along its posterior border; lower jaw light orange; iris dark brown; chin flesh colour with a few spots of orange; throat flesh colour; neck very pale straw colour above, flesh colour beneath, becoming deeper when the animal is irritated; anterior extremities light straw colour, lighter upon the humerus, and in the axilla. Posterior extremities and tail of a uniformly light straw colour. Shell deep chestnut-brown, lighter in front upon the anterior vertebral, and the anterior marginal plates ; the costal plates are bordered inferiorly with yellow, most perceptible upon the two first. In some specimens the ground colour of the first and second costal is yellow, the chestnut appearing in the form of rays; sternum black, bordered with light yellow; in very old specimens the yellow predominates, the black appearing in the form of large blotches. 


\section{Dimensions.}

Inches, Lines.

Length of head, -

Breadth of head, measured from the anterior angle of one orbit to the corresponding angle of the other, - $\quad-0 \quad \begin{array}{lll}0 & 10\end{array}$

From posterior angle of ditto, $\quad-\quad \begin{array}{llll} & - & 0 & 12\end{array}$

Greatest breadth posteriorly, $\quad-\quad \begin{array}{llll} & & 1 & 3\end{array}$

Height of head, measured in a line with

posterior angle of lower jaw, - $\quad-\quad \begin{array}{lll}9 & 0\end{array}$

Length of neck, - - - $\quad$ - $\quad-30$

Length of anterior extremities, - $\quad-5^{\frac{1}{2}} 0$

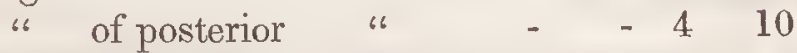

Length of tail, - $\quad$ - $\quad$ - $\quad$ - $\quad$ - 30

Length of carapace, following line of curvature,
$-120$

Breadth, measured in the middle, and in

the same manner, - $\quad-\quad-810$

Length of anterior portion of sternum, $3 \quad 6^{\frac{3}{2}}$

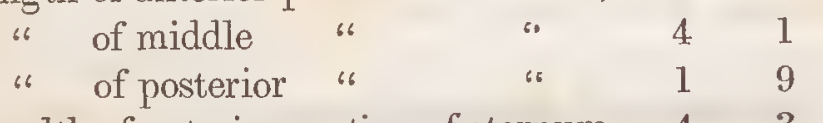

Breadth of anterior portion of sternum, $4 \quad 3$

"6 of middle " " 4070

" of posterior, " $\quad$ " $\quad 5 \quad 5 \quad 2$

Height of shell, - $\quad$ - $\quad$ - $\quad$ - $\quad$ - 40

The first notice we have of this species is by Shaw, in the third volume of the General Zoology, in. which he describes the shell of the young animal, and gives, as a synonyme, the Testudo denticulata, of Linnæus, which is now ascertained to be the young of the tabulata. Schweigger next de- 
scribed it in his Prodromus to the Konigsberg Transactions, under the name of erosa, in order to distinguish it from the denticulata of Linnæus, which he had ascertained to be a different animal. The next notice we have of it is by Mr. Bell, whose description was drawn up chiefly from the shell of an adult specimen, on which he founded the present genus. He calls it castanea, from the chestnut color of the carapace, and considers it a new species. Mr. Gray, in his Synopsis Reptilium, describes it under the name of KinIXIs erosa, retaining the generic name of Bell, and the specific appellation of Schweigger. In this he is followed by Dumeril and Bibron, in their Natural History of Reptiles, now in course of publication. But inasmuch as Shaw was the first to describe the animal, although in its young state, it is evident that his name should be retained. 'The very strongly marked denticulations which characterize this species, differing, as it does, in this respect from the others which belong to the genus, make it, moreover, quite appropriate.

Habits and Geographical Distribution.-Not much is known of the habits of this animal in its native haunts; in a state of captivity its movements appeared remarkably sluggish, being seldom found at a great distance from the part of the garden in which it was deposited. He generally selected a shady place alongside the fence or wall, and in the neighborhood of running water, of which he drank at times profusely. His food consisted of fruits and vegetables, chiefly, as apples, pears, Irish and Sweet 
potatoes, \&c., but he was also fond of meat, both in its cooked and raw state.

The Kinixis denticulata is undoubtedly a native of Africa. Dumeril and Bibron 'give Guadaloupe as its habitat, on the authority of Mr. Gray, but the present specimen, with two shells of the same species was brought in the Saluda, direct from Liberia, whither she had been for the purpose of conveying emigrants. It was sent to Dr. Blanding by the Rev. James Eden, one of the colonists of New Georgia, who states that they inhabit, in great numbers, the shady banks of the St. Paul and Mesurado rivers, and that they die in a short time, if exposed to the rays of the hot sun.

พOL. VIII. -1839. 
Description of a New Species of Fuligula. By George C. Leib, M. D.

Read January 7th, 1840.

Fuligula grisea.

This duck was procured in the market of Philadelphia, on the 15th of December, 1839, but no information concerning its history could be obtained, further, than that it was shot in the neighborhood of Great Egg Harbour, New Jersey. The stomach contained small, broken shells.

Specific Characters.-Speculum and throat white; bill expanded and tumid; teeth remarkably developed; plumage dark gray, inclining to fuscous.

Female, uniform grayish-ash.

Description.-Length of bill, above, one inch and seven-tenths; breadth, eight-tenths ; length of lower mandible from rictus, two inches and three-tenths; breadth, nine-tenths. Upper mandible black, with a large, pale, livid space at base, including the nostrils, which are soft and patulous, open and oblong; near the tip the edges are spread out and elongated by a membranous appendage, soft and extensible; a slightly curved line or furrow is traced from the sides of the unguis, half-way to the base. Inferior edges of the lower mandible pale flesh color, the tip, and connecting membrane, black; teeth remarkably large and broad. The whole head and cheeks are dark grayish-fuscous; a crescentic band 
of cream color beneath, and partly behind the eye ; back of the neck, and whole dorsal plumage, light grayish-plumbeous; shafts of the scapulars blackish; rump and upper tail-coverts dark grayish-fuscous; tail three and a quarter inches in length, rounded, dusky, of fourteen feathers; primaries black, first and second longest; secondaries white, forming a speculum upon the wing when closed; this consists of ten feathers, the four first, from the base, for two-thirds of their length, dusky; the five adjoining are of the same color for the like distance on their inner vanes, the tenth has a similar mark

Since writing the within, I have discovered that this bird is the young of the labradora, in a plumage heretofore undescribed or figured; which circumstance is sufficient to render it interesting to naturalists.

G. C. I.

the male large.

The female is of an uniformly lighter color, approaching to ash, and wants the pectoral band and white throat, but in other respects resembles the male. 
Description of a New Species of Fuligula. By George C. Leib, M. D.

Read January 7 th, 1840.

Fuligula grisea.

THIs duck was procured in the market of Philadelphia, on the 15th of December, 1839, but no information concerning its history could be obtained, further, than that it was shot in the neighborhood of rannt $n$

preadth, nine-tenths. Upper mandible black, with a large, pale, livid space at base, including the nostrils, which are soft and patulous, open and oblong; near the tip the edges are spread out and elongated by a membranous appendage, soft and extensible; a slightly curved line or furrow is traced from the sides of the unguis, half-way to the base. Inferior edges of the lower mandible pale flesh color, the tip, and connecting membrane, black; teeth remarkably large and broad. The whole head and cheeks are dark grayish-fuscous; a crescentic band 
of cream color beneath, and partly behind the eye; back of the neck, and whole dorsal plumage, light grayish-plumbeous; shafts of the scapulars blackish ; rump and upper tail-coverts dark grayish-fuscous; tail three and a quarter inches in length, rounded, dusky, of fourteen feathers; primaries black, first and second longest; secondaries white, forming a speculum upon the wing when closed; this consists of ten feathers, the four first, from the base, for two-thirds of their length, dusky; the five adjoining are of the same color for the like distance on their inner vanes, the tenth has a similar mark as far as the tip. Irids light brown. Chin and throat white. Whole lower parts uniform dark grayish-fuscous; axillaries and internal wing-coverts grayish-white; an indistinct pectoral band of whitish, varied with rufous; legs and feet dusky, webs darker; length of tarsus one inch and eighttenths; middle toe, two and a half inches; hind toe, six-tenths. The labarynth in the trachea of the male large.

The female is of an uniformly lighter color, approaching to ash, and wants the pectoral band and white throat, but in other respects resembles the male. 


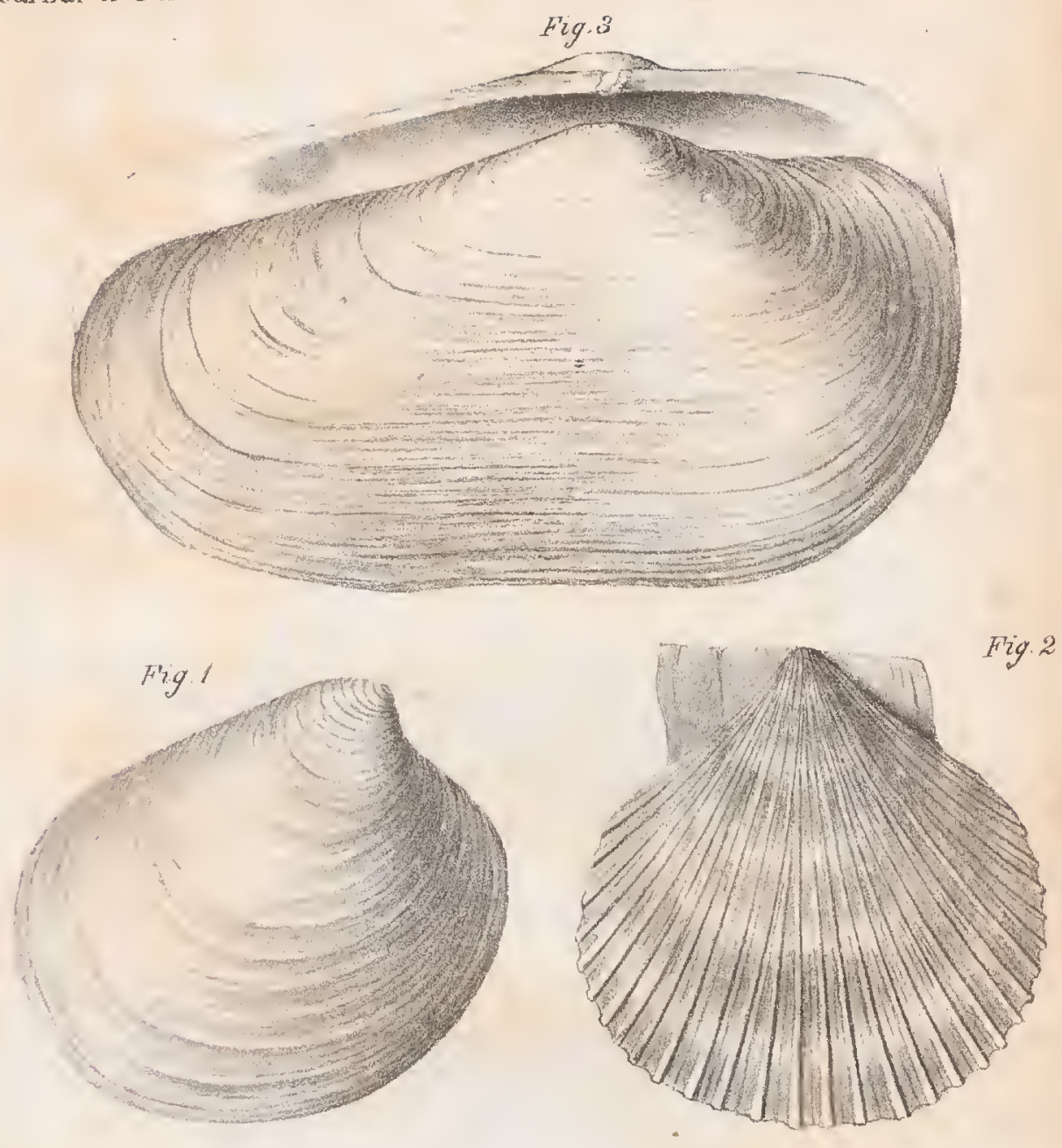

Fig 5

Fig 4
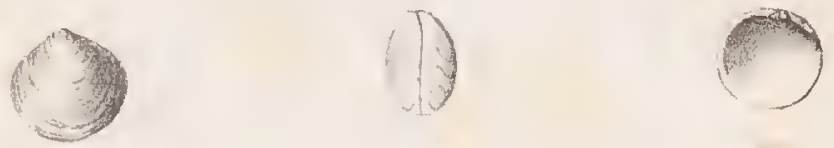

J. Collins

Sinclarr's Lith. 


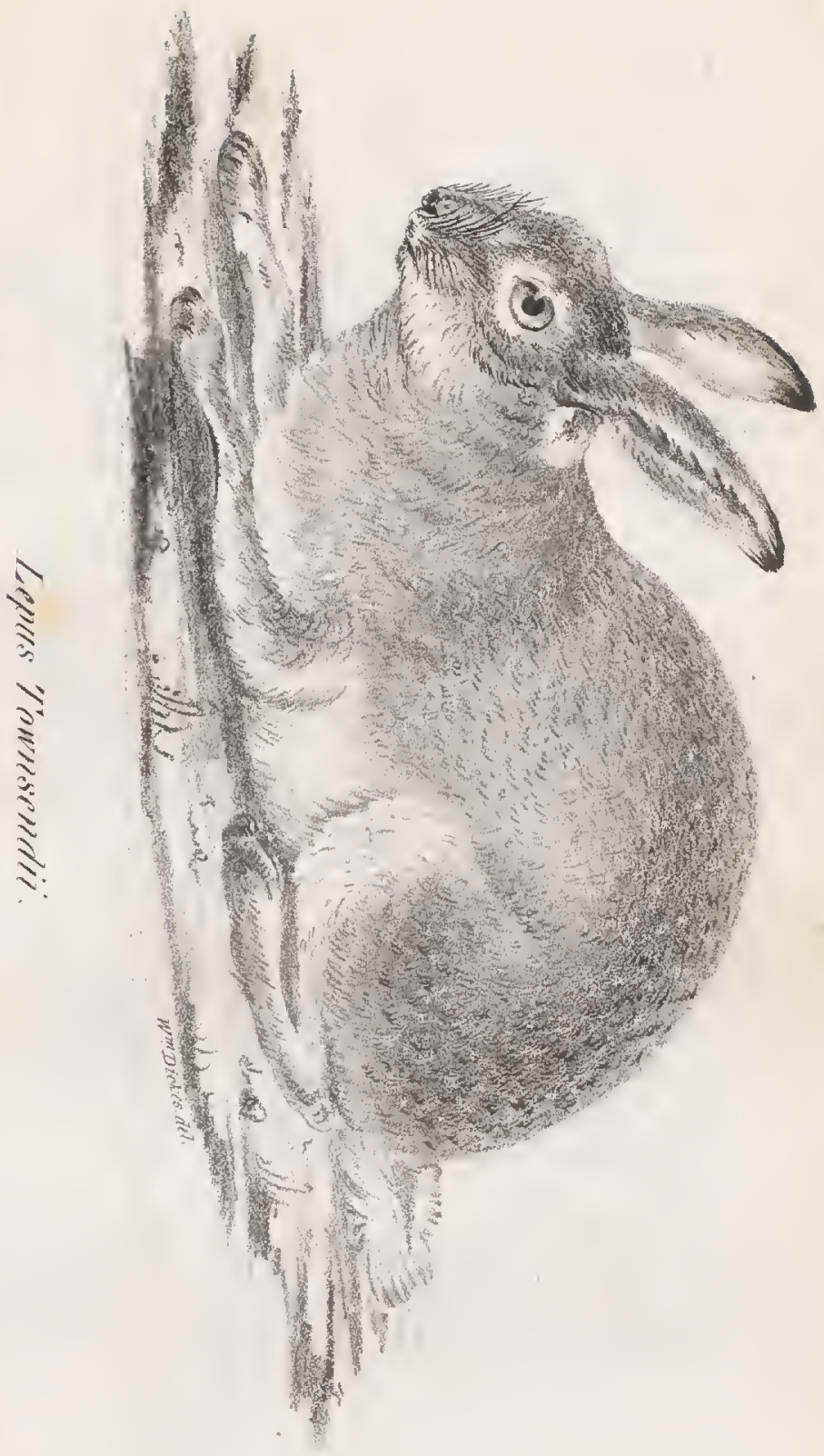





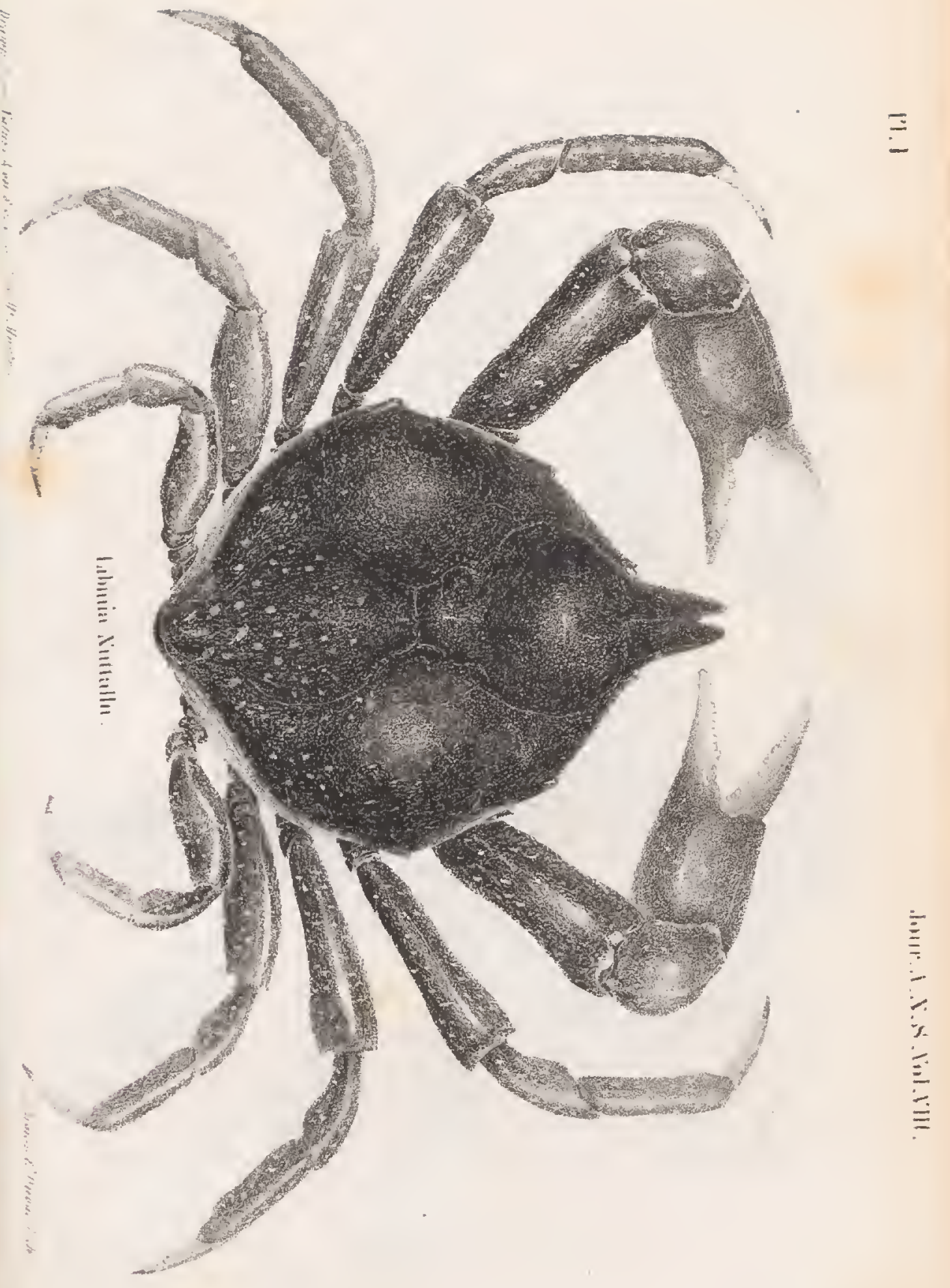





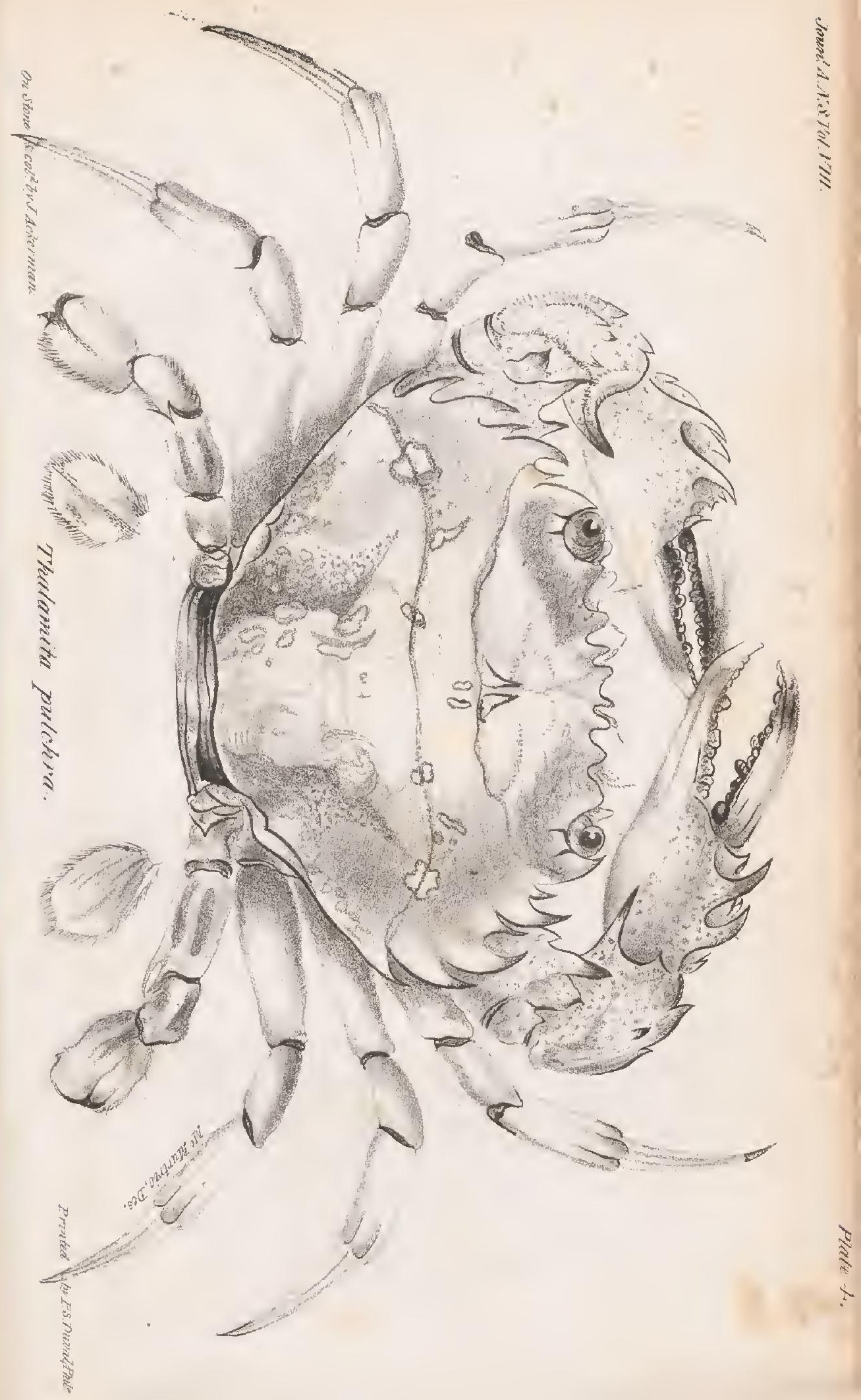




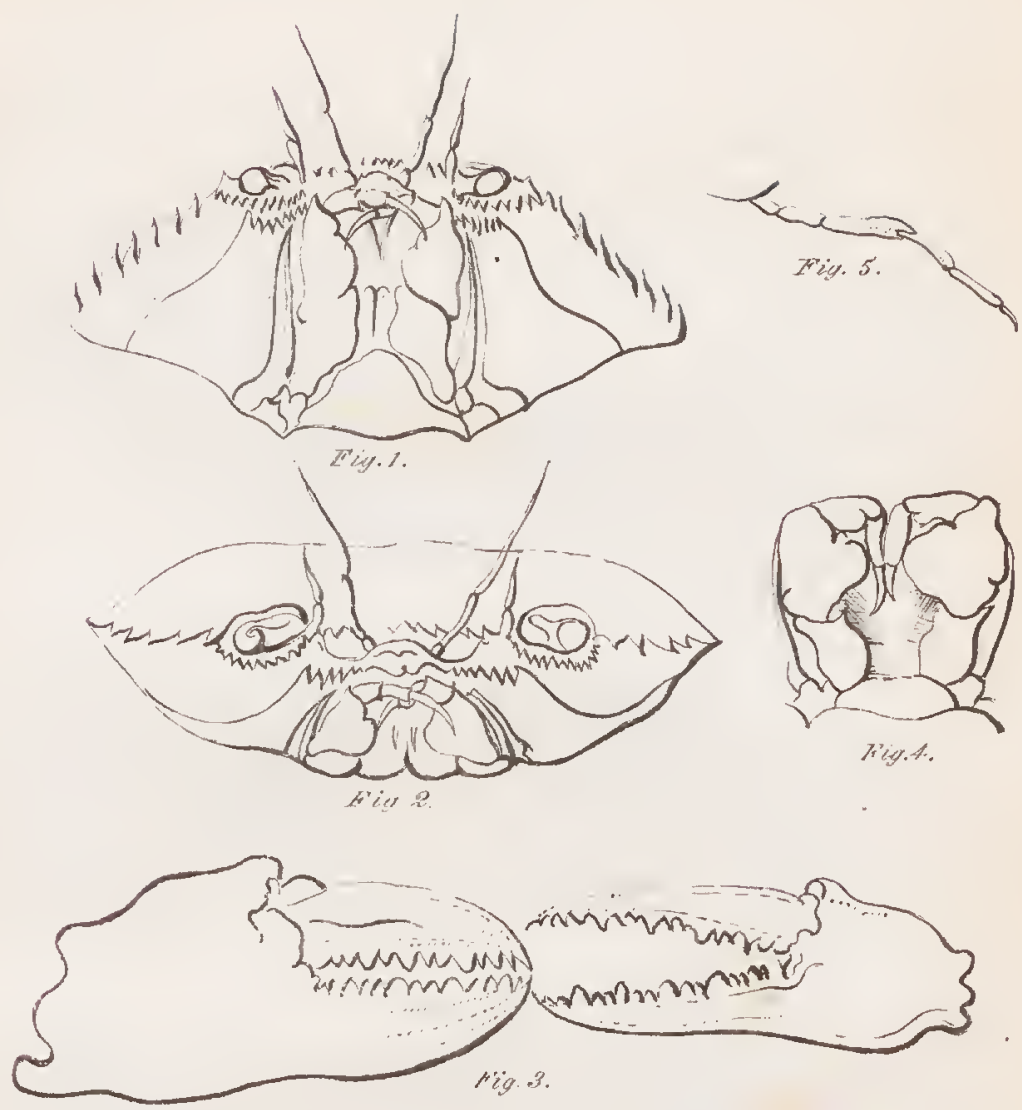

REFETENCFA.

Figs.- 1, 2\&3,-Detaits of Orthostama dentate:

Wig. 4, The outer Maxillary feet of Paihyrapsis.

Fig. 5, Third foot of atyoidu bisureato. 



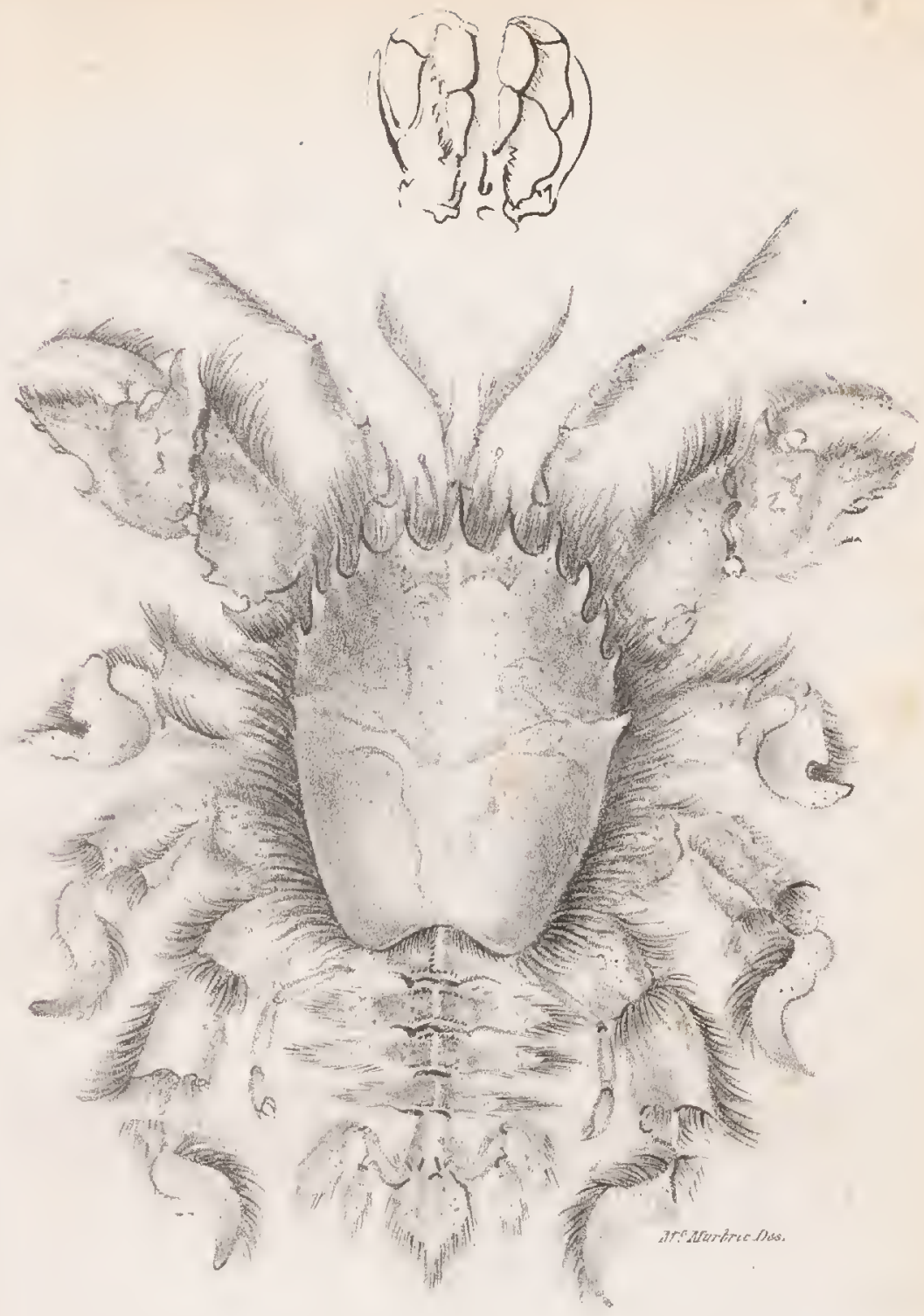

Filepharzandex. Occidentulis 



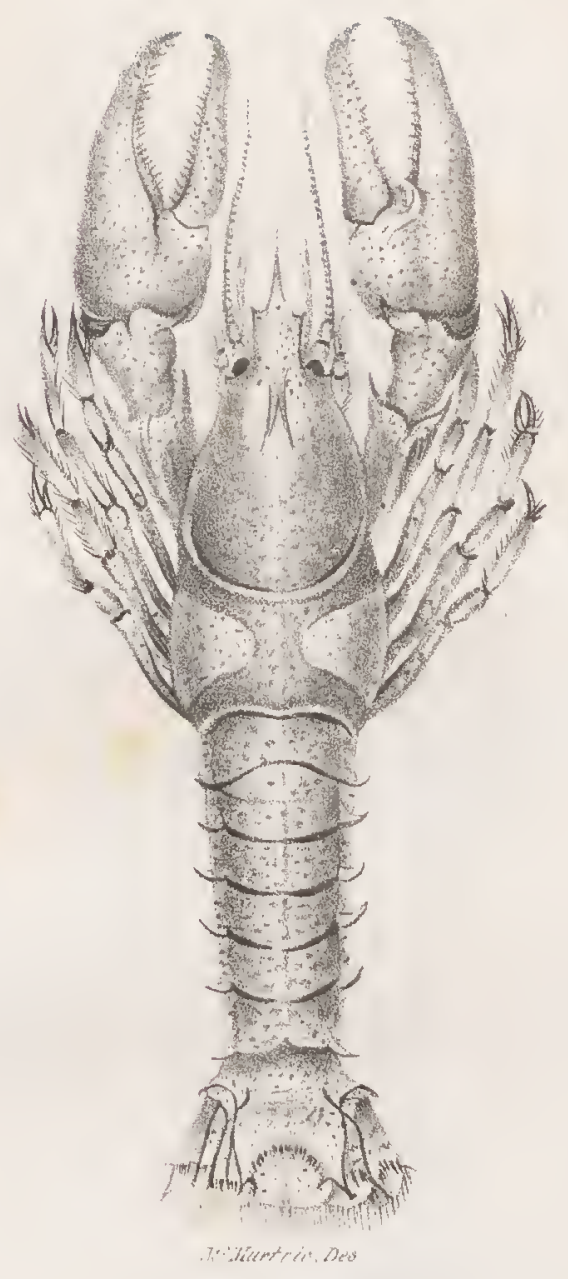

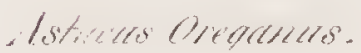





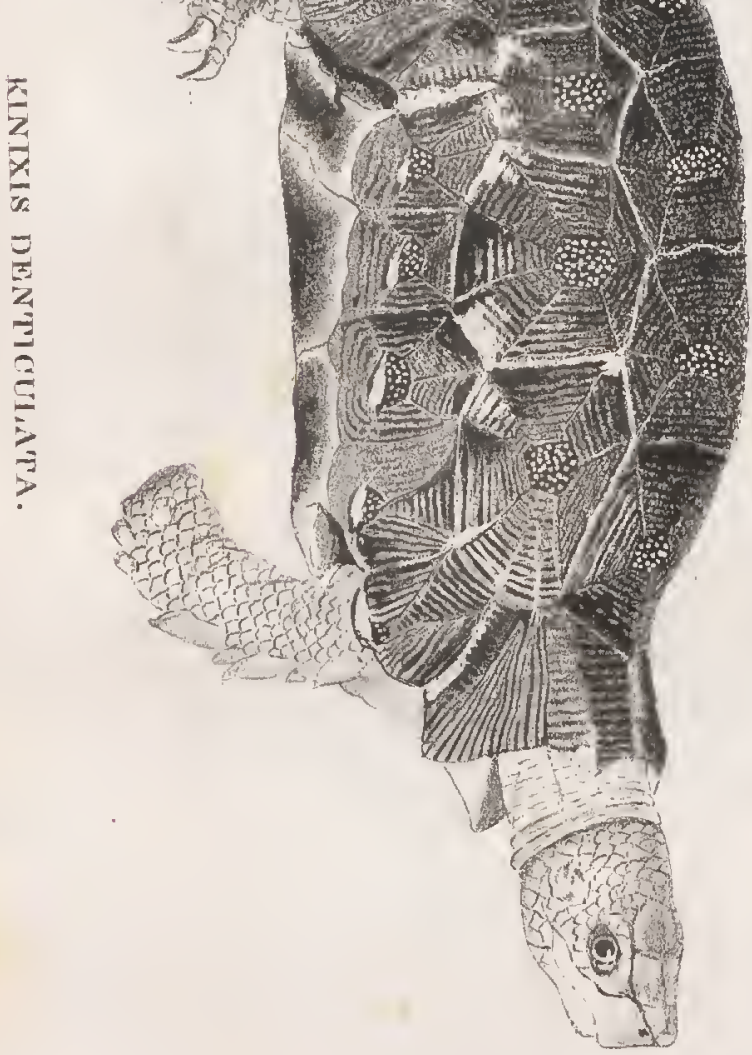

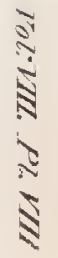





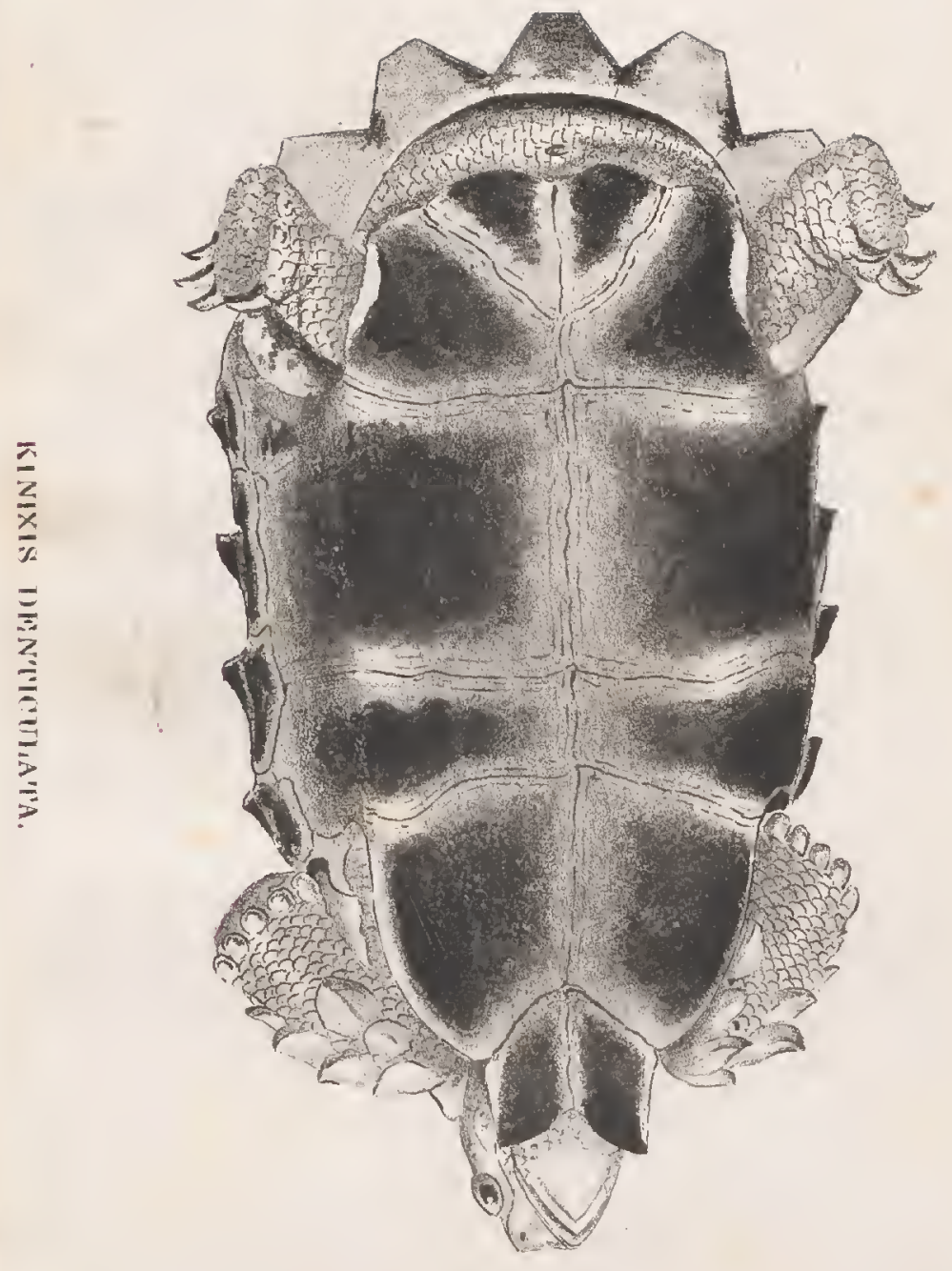

है

춘 





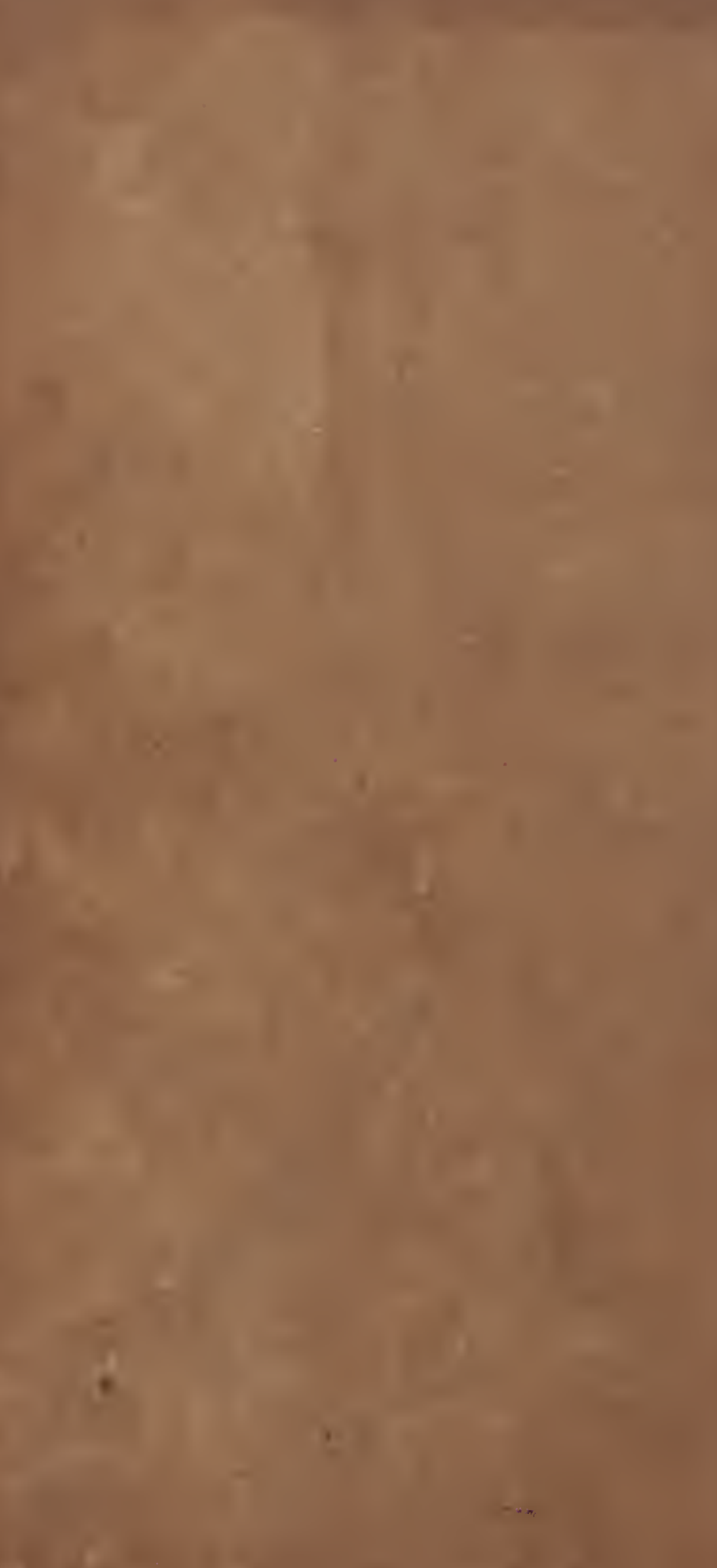

